\title{
FINAL REPORT DEVELOPMENT OF A THERMAL AND WATER MANAGEMENT SYSTEM FOR PEM FUEL CELL
}

\author{
11-77418, REV. 1 \\ OCTOBER 5, 2012
}

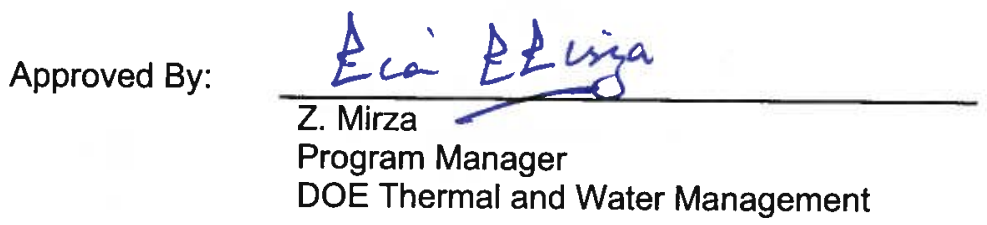

Note: Signatures of document approvers or their designees are captured electronically via the Product Data Management (PDM) System. 
REVISION HISTORY

\begin{tabular}{|c|l|l|l|l|}
\hline Rev & \multicolumn{1}{|c|}{ By } & \multicolumn{1}{|c|}{ Approved } & \multicolumn{1}{c|}{ Date } & \multicolumn{1}{c|}{ Revision Summary } \\
\hline 0 & Staff & Z. Mirza & December 6, 2011 & Initial issue. \\
\hline 1 & Staff & Z. Mirza & October 5, 2012 & $\begin{array}{l}\text { Deleted "Honeywell Confidential" legend from } \\
\text { title page and from footer of each page. }\end{array}$ \\
\hline
\end{tabular}


TABLE OF CONTENTS

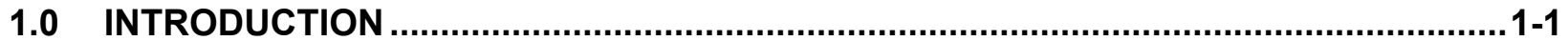

$1.1 \quad$ Acronyms and Abbreviations ................................................................... 1-2

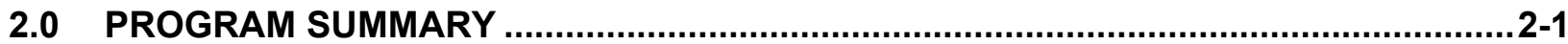

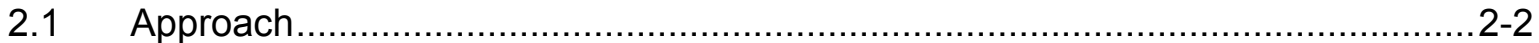

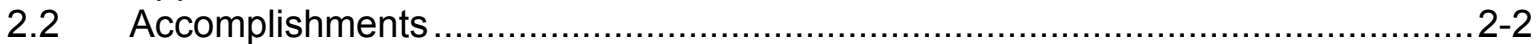

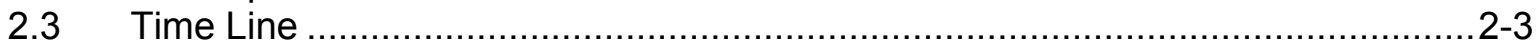

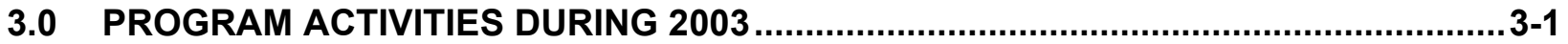

4.0 PROGRAM ACTIVITIES DURING 2004

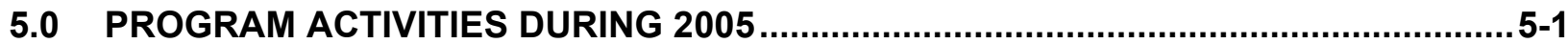

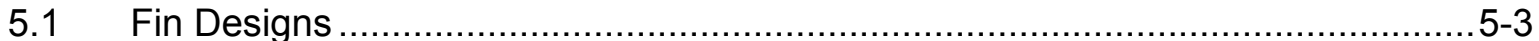

5.1.1 Design Optimization Strategy …………….............................. $5-3$

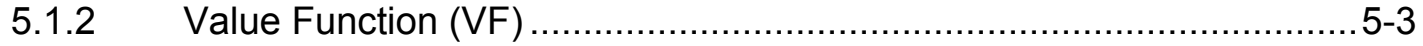

5.1.3 Fin Height Optimization ................................................................5-5

5.1.4 Foam Fin Optimization ............................................................ $5-6$

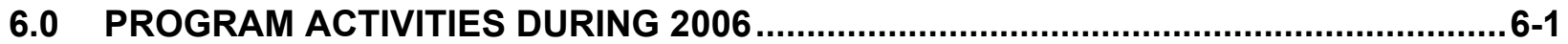

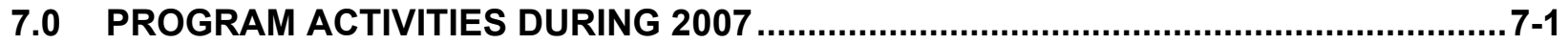

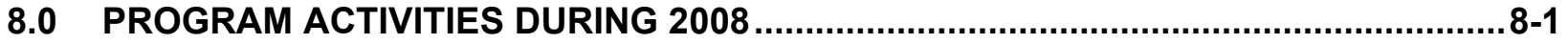

$8.1 \quad$ Sub-Scale Radiators …………….......................................................

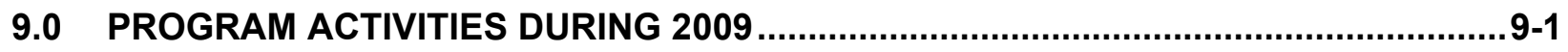

$9.1 \quad$ Thermal Management ............................................................................ $9-1$

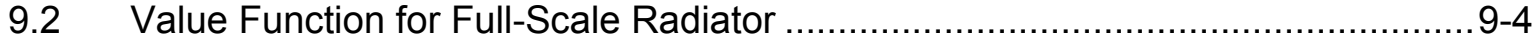

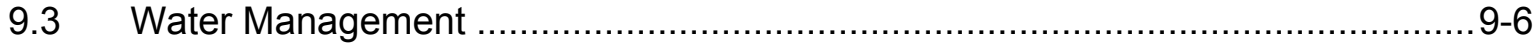

9.4 Water Management Test Stand Changes...................................................... 9-6

9.5 Proposed Test Points......................................................................... 9-10

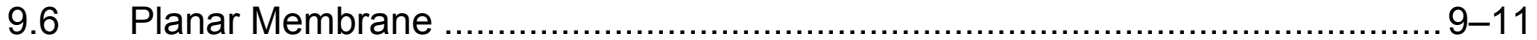

9.6.1 Fabrication of Full-Scale Radiators ............................................ 9-12

9.6.2 Radiator Test Stand ….......................................................... 9-13

9.6.3 Full-Scale Radiator Test Data .................................................. 9-14

9.7 Manufacturing Lessons Learned................................................................ 9-15

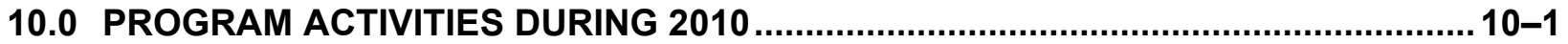

10.1 Water Management ……….................................................................10-1

10.2 Full-scale Membrane Module Testing …………....................................10-3

10.3 Sub-scale Membrane Module Testing ………......................................10-5

10.4 Planar Membrane Module Testing …….................................................... 10-8 
10.5 Thermal Management ...........................................................................

11.0 PROGRAM ACTIVITIES DURING 2011 ............................................................11-1

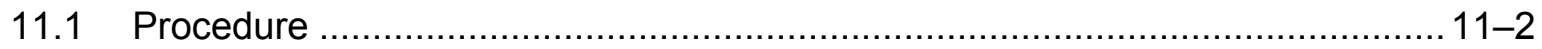

LIST OF FIGURES

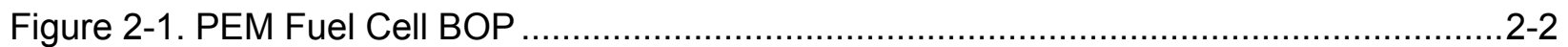

Figure 4-1. Surfaces Considered for Study................................................................. $4-1$

Figure 4-2. TWM Radiator Face Area vs. Value Function ............................................. $4-2$

Figure 4-3. TWM Radiator Power vs. Value Function................................................. 4-2

Figure 5-1. Microchannel Sub-Scale Heat Exchanger ...................................................... 5-1

Figure 5-2. Aluminum Foam Sub-Scale Prototype .......................................................... 5-2

Figure 5-3. Isothermal Fanning Friction Factor $f$ in High Aspect Ration Microchannel ............5-2

Figure 5-4. Value Function and Total Power vs. Fin Height ........................................... 5-4

Figure 5-5. Value Function and Total Power vs. Fin Height ............................................ 5-5

Figure 5-6. Foam Fin - Value Function vs. Frontal Area .............................................. $5-6$

Figure 5-7. Foam Fin - Power vs. Frontal Area ........................................................ 5-7

Figure 5-8. Foam Fin - Radiator Wet Weight vs. Frontal Area ..................................... 5-8

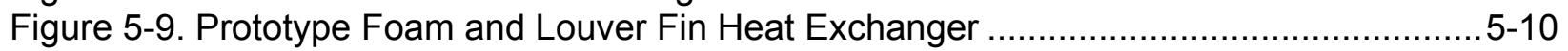

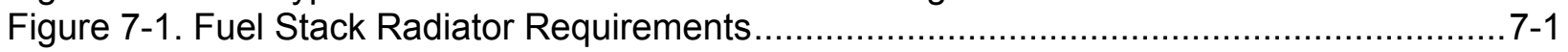

Figure $7-2$. Value Function and Variables ........................................................... $7-2$

Figure 8-1. Sub-scale Radiators for Four Candidate Configurations ................................ 8-1

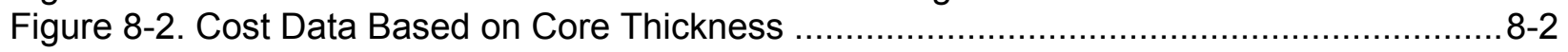

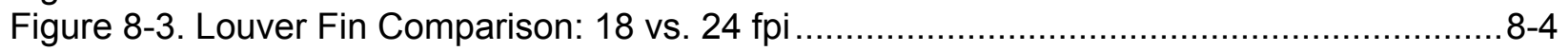

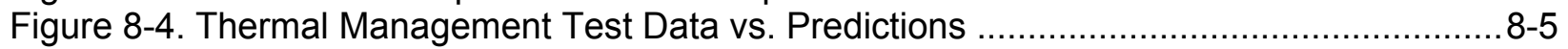

Figure 8-5. Microchannel Fin Comparison: 40 vs. 50 fpi .......................................... $8-6$

Figure 9-1. Thermal Management Test Data vs Predictions .............................................. 9-1

Figure 9-2. Fin Micrograph Showing Differences Between 40-fpi and 50-fpi

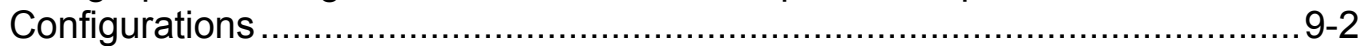

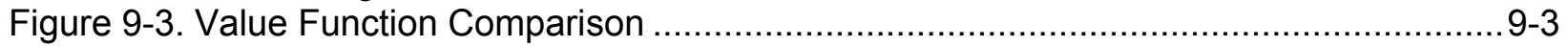

Figure 9-4. Total Cost Comparison ....................................................................... $9-4$

Figure 9-5. Final Value Function Comparison ............................................................

Figure 9-6. Radiator Cost Breakdown..........................................................................

Figure 9-7. Current Test Stand Schematic ......................................................................... 9

Figure 9-8. Revised Test Stand Schematic ............................................................... 9-10

Figure 9-9. Planar Membrane Module ....................................................................... 9-12

Figure 9-10. Full-Scale Radiator with 18-fpi Louver Fins .............................................. 9-12

Figure 9-11. Full-Scale Radiator with 40-fpi Microchannel Fins ...................................... 9-13

Figure 9-12. Face of Radiator Instrumented for Testing ............................................. 9-13

Figure 9-13. Glycol-Water Circulating Cart .................................................................... 9-14

Figure 9-14. Performance of Full-Scale Radiator with 18 fpi Louvered Fins....................... 9-14

Figure 9-15. Performance of Full-Scale Radiator with 40 fpi Microchannel Fins ..................9-15

Figure 10-1. Example of Secondary Inlet Temperature Stratification for Case 6 and

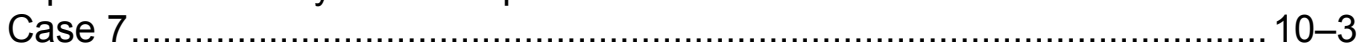

Figure 10-2. Humidity of Inlet and Outlet Streams Compared with Average Flow Rates to Humidifier Inlet and Outlet Flow Streams.............................................. 10-4

Figure 10-3. Sub-scale Membrane Module Under Test.................................................. 10-5

Figure 10-4. Fuel Cell Inlet RH vs. Fuel Cell Exit RH ................................................. 10-6 
Figure 10-5. Fuel Cell Inlet RH vs. Fuel Cell Exit RH and Trend Extrapolated to 100 Percent Exit RH.

Figure 10-6. Water Mass Balance Percent as a Function of Boiler Water Feed Rate....... 10-7

Figure 10-7. Water Mass Balance Percent as a Function of Boiler Water Feed Rate, Repeat Test Data

Figure 10-8. Full-scale Planar Membrane Module $10-9$

Figure 10-9. Water Transfer Ratio as a Function of Total Water Flow. $10-10$

Figure 10-10. Water Balance Error as a Function of Total Water Flow $10-10$

Figure 11-1. Test Stand Schematics for Reliability Test 11-3

Figure 11-2. Typical 2-Minute Humidity Cycles $11-4$

Figure 11-3. Typical 2-Minute Humidity Cycles $11-4$

Figure 11-4. Membrane Module Air Leakage Rate $11-5$

Figure 11-5. Typical 2-Minute Humidity Cycles $11-6$

Figure 11-6. Typical 2-Minute Humidity Cycles 11-6

Figure 11-7. Membrane Module Air Leakage Rate... $11-7$

Figure 11-8. Enthalpy Wheel Installed in Test Stand $11-8$

Figure 11-9. Enthalpy Wheel Air Leakage Rate $11-8$

\section{LIST OF TABLES}

Table 2-1. Technical Targets for PEM Fuel Cell TWM System

Table 2-2. Time Line

Table 5-1. Fin Dimensions

Table 8-1. Sub-scale Radiator Performance.

Table 9-1. Proposed Humidification Test Points

Table 10-1. Full-scale Membrane Module Inlet Conditions and Water Balance $10-2$

Table 10-2. Planar Membrane Module Test Matrix..... 10-11

\section{LIST OF APPENDICES}

Appendix A. DOE Fuel Cell Thermal Management System Critical Design Review, November 14, 2008

Appendix B. Development of Thermal and Water Management System for PEM Fuel Cell FY2011 Plan 


\section{Honeywell}

\subsection{INTRODUCTION}

This final program report is prepared to provide the status of program activities performed over the period of 9 years to develop a thermal and water management (TWM) system for an 80-kW PEM fuel cell power system. The technical information and data collected during this period are presented in chronological order by each calendar year, even though the program funding was provided on fiscal year basis.

Regular quarterly reports were submitted to the U.S. Department of Energy (DOE), and presentations were made yearly at DOE Hydrogen Program Annual Merit Review and Peer Evaluation meetings.

This report is submitted by Honeywell Aerospace, Torrance, CA, to the DOE for work done under Contract FC36-03G013109.

Specifics of the program are as follows:

Project Title: $\quad$ Development of a Thermal and Water Management (TWM) System for PEM Fuel Cells

Project Period: $\quad$ September 2003 through November 2011

Date of Report: $\quad$ December 6, 2011

Recipient: Honeywell Aerospace

Company Address: $\quad 2525$ West $190^{\text {th }}$ Street, Torrance, CA 90504

Award Number: $\quad$ DE-FC36-03G013109

Working Partners: $\quad$ Emprise Corporation, Perma Pure LLC, Argonne National Laboratory (ANL)

Cost-Sharing Partners: Honeywell

Contacts: $\quad$ Program Manager/Principal Investigator:

Zia Mirza, 310-512-3374

zia.mirza@honeywell.com

Contract Manager:

Jon Lawler, 727-539-2256

jon.d.lawler @honeywell.com

DOE Managers:

$\mathrm{HQ}$ Technology Manager:

Jason Marcinkoski, 202-586-7466

jason.marcinkoski@ee.doe.gov

Program Manager:

Reginald Tyler, 303-275-4929

reginald.tyler@go.doe.gov 


\subsection{Acronyms and Abbreviations}

$\begin{array}{ll}\text { ANL } & \text { Argonne National Laboratory } \\ \text { BOP } & \text { Balance of Plant } \\ \text { BTU } & \text { British Thermal Unit } \\ \text { CDR } & \text { Critical Design Review } \\ \text { DOE } & \text { U.S. Department of Energy } \\ \text { fpi } & \text { Fins per Inch } \\ \text { HTS } & \text { Honeywell Transportation Systems } \\ \text { inHg } & \text { Inches of Mercury } \\ \text { LxWxH } & \text { Length by Width by Height } \\ \text { OEM } & \text { Original Equipment Manufacturer } \\ \text { PEM } & \text { Proton Exchange Membrane } \\ \text { psi } & \text { Pounds per Square Inch } \\ \text { Re } & \text { Reynolds Number } \\ \text { RH } & \text { Relative Humidity } \\ \text { RTD } & \text { Resistance Temperature Detector } \\ \text { TWM } & \text { Thermal And Water Management } \\ \text { UoC } & \text { University of Cincinnati } \\ \text { UUT } & \text { Unit Under Test } \\ \text { VF } & \text { Value Function }\end{array}$




\section{Honeywell}

\subsection{PROGRAM SUMMARY}

Balance of plant (BOP) components of a PEM fuel cell automotive system represents a significant portion of total cost based on the 2008 study by TIAX LLC, Cambridge, MA. The objectives of this TWM program were two-fold:

- Develop an advanced cooling system (efficient radiator) to meet the fuel cell cooling requirements. The heat generated by the fuel cell stack is a low-quality heat (small difference between fuel cell stack operating temperature and ambient air temperature) that needs to be dissipated to the ambient air. To minimize size, weight, and cost of the radiator, advanced fin configurations were evaluated.

- Evaluate air humidification systems which can meet the fuel cell stack inlet air humidity requirements. The moisture from the fuel cell outlet air is transferred to inlet air, thus eliminating the need for an outside water source. Two types of humidification devices were down-selected: one based on membrane and the other based on rotating enthalpy wheel. The sub-scale units for both of these devices have been successfully tested by the suppliers.

This project addresses the following technical barriers from the DOE Fuel Cell section of the Hydrogen, Fuel Cells, and Infrastructure Technologies Multi-year Research, Development and Demonstration Plan:

- (E) System Thermal and Water Management

The technical target established for this program is presented in Table 2-1.

Table 2-1. Technical Targets for PEM Fuel Cell TWM System

\begin{tabular}{|l|l|l|l|}
\hline \multicolumn{1}{|c|}{ Characteristics } & \multicolumn{1}{|c|}{ Units } & \multicolumn{1}{|c|}{ Target } & \multicolumn{1}{|c|}{$\begin{array}{c}\text { Honeywell } \\
\text { Status }\end{array}$} \\
\hline Relative humidity of PEM cell stack inlet air & $\begin{array}{l}\% \text { at } 176^{\circ} \mathrm{F} \\
\left(80^{\circ} \mathrm{C}\right)\end{array}$ & $>60$ & $50 \%$ \\
\hline $\begin{array}{l}\text { Cooling requirements with } 185^{\circ} \mathrm{F}\left(85^{\circ} \mathrm{C}\right) \text { coolant } \\
\text { temperature and flow rate of } 2.5 \mathrm{~kg} / \mathrm{sec} \text {, with frontal } \\
\text { area not to exceed } 3.44 \text { sq-ft }(0.32 \mathrm{sq} \text { meter) }\end{array}$ & $\mathrm{kW}$ & 50 & 50 \\
\hline Radiator cost (by TIAX LLC) without markup & $\$$ & 57 & 60 \\
\hline Reliability of radiator & $\mathrm{Hrs}$ & 5000 & $>5000$ \\
\hline Total parasitic power (air fan + cooling pump) & $\mathrm{kW}$ & $<2.4$ & TBD \\
\hline
\end{tabular}

PEM Fuel Cell BOP is presented in Figure 2-1, where air, water, and thermal management subsystems are identified. 


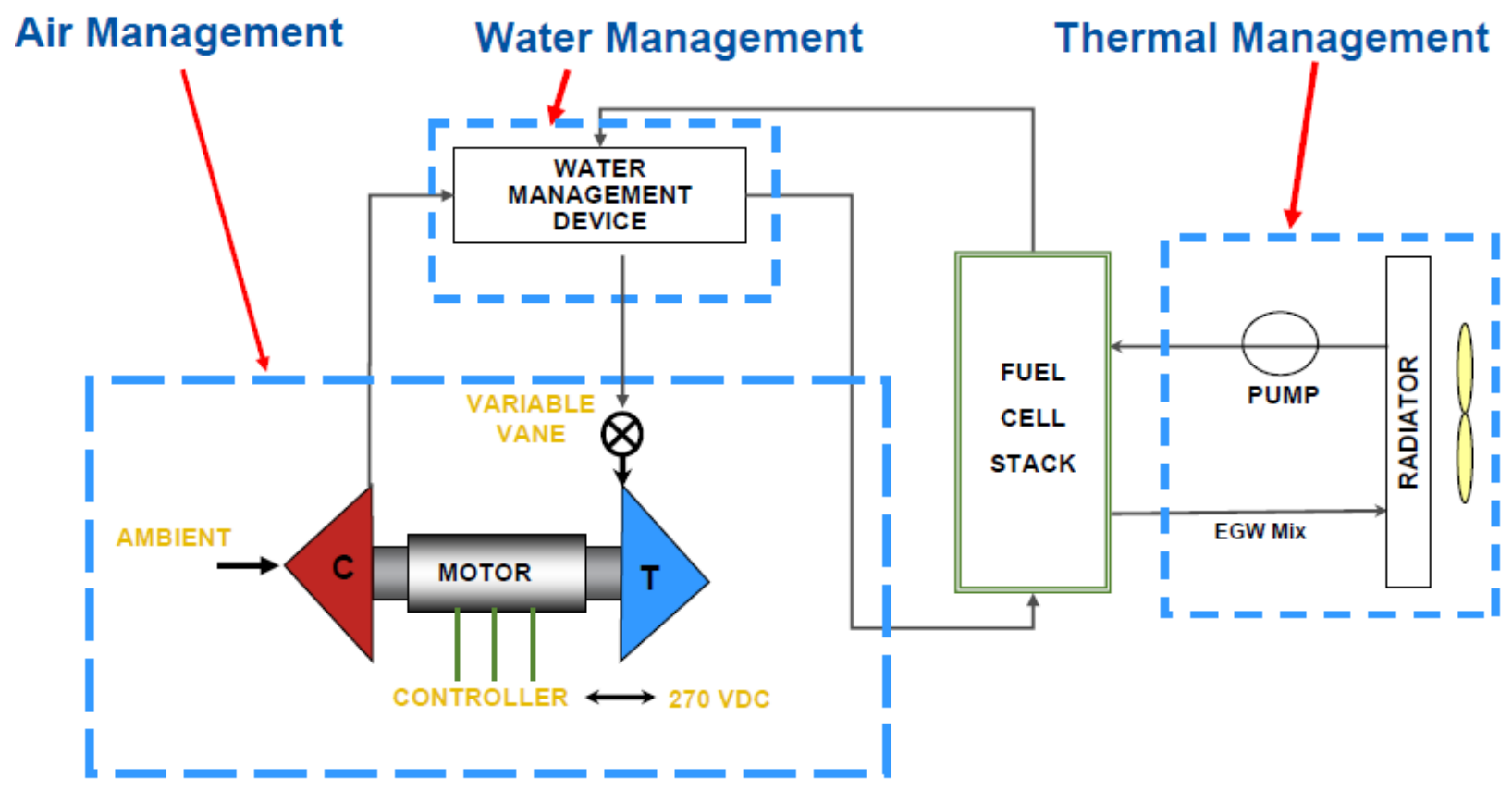

Figure 2-1. PEM Fuel Cell BOP

\subsection{Approach}

To develop a high-performance radiator for a fuel cell automobile, various advanced surfaces were evaluated, including foam; advanced, offset, and slit louver fins; and microchannel with various fin densities. A value function was developed to evaluate and compare the cost of various fin geometry radiators. The value function was based on the cooling system weight, performance, parasitic power, and initial cost. Two fin geometries, $18 \mathrm{fpi}$ louver and $40 \mathrm{fpi}$ microchannel, were down-selected. The full-scale radiators were built and tested. The test results for the two radiators were presented in the final test report submitted in 2009.

Two different configurations, a full-scale membrane module and an enthalpy wheel, were selected and tested to validate their performance and reliability. A test stand was designed and built to test the selected humidification devices where fuel cell stack operating conditions were simulated. The select humidifiers were tested for their reliability for up to 5,000 cycles.

\subsection{Accomplishments}

- Thermal Management portion of the program was successfully completed and the final test report for the thermal management was submitted to DOE in December 2009. The full-scale radiator performance test data was provided to Argonne National Laboratory for their fuel cell system model.

- Water Management

o The humidification system test stand was designed and built to simulate the fuel cell operating conditions

o The full-scale and sub-scale membrane humidifier system and the enthalpy wheel humidifier were successfully tested. The water transfer efficiency was slightly lower than the required 60 percent. 


\section{Honeywell}

o Two select humidifiers were successfully tested for 5,000 cycles, each at fuel cell operating condition.

\subsection{Time Line}

A timeline for this nine-year program is provided in Table 2-2 showing the major activities by year. Due to funding issues, DOE has stopped the funding for 20 months, which caused an additional 2-month delay in program stop and restart activities.

Table 2-2. Time Line

\begin{tabular}{|c|c|c|c|c|c|c|c|c|c|}
\hline Activities & 2003 & 2004 & 2005 & 2006 & 2007 & 2008 & 2009 & 2010 & 2011 \\
\hline $\begin{array}{l}\text { Program Kickoff, Planning } \\
\text { and Scope definition }\end{array}$ & $=$ & & & & & & & & \\
\hline $\begin{array}{l}\text { Radiator Performance } \\
\text { Evaluation and Trade } \\
\text { Studies }\end{array}$ & & & & & & & & & \\
\hline $\begin{array}{l}\text { Sub-scale Radiator built, } \\
\text { value function established } \\
\text { and Radiator design } \\
\text { compared }\end{array}$ & & & & & & & & & \\
\hline Program on Hold by DOE & & & & & & & & & \\
\hline $\begin{array}{l}\text { Cooling requirements and } \\
\text { Value function finalized }\end{array}$ & & & & & 프 & & & & \\
\hline $\begin{array}{l}\text { Sub-scale Radiator built, } \\
\text { tested and data validated }\end{array}$ & & & & & & & & & \\
\hline $\begin{array}{l}\text { Full size radiator built, } \\
\text { tested } \& \text { model validated. } \\
\text { Humidifier test stand } \\
\text { checked out }\end{array}$ & & & & & & & & & \\
\hline $\begin{array}{l}\text { Performance tested three } \\
\text { humidifiers }\end{array}$ & & & & & & & & & \\
\hline $\begin{array}{l}\text { Reliability tested two } \\
\text { humidifiers }\end{array}$ & & & & & & & & & 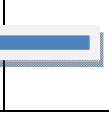 \\
\hline
\end{tabular}




\subsection{PROGRAM ACTIVITIES DURING 2003}

Most of the efforts in 2003 were focused on programmatic issues. Tasks accomplished included risk mitigation of vendor commitment, dialogue with Argonne National Laboratory for fuel cell characterization, DOE kick-off meeting for determining program scope, Honeywell internal kickoff meeting, and communication with fuel cell and automotive OEMs in 2003 Fuel Cell Seminar. In addition, a system concept analysis was started in the fourth-quarter of 2003 and continued through 2004. 


\section{Honeywell}

This page has been deleted because it was deemed to contain Honeywell Confidential information. 


\section{Honeywell}

This page has been deleted because it was deemed to contain Honeywell Confidential information. 


\section{Honeywell}

\subsection{PROGRAM ACTIVITIES DURING 2005}

After selecting the aluminum foam and microchannel surfaces for the fuel cell automobile application, it was decided to build and test sub-scale heat exchangers. The primary objective was to evaluate the manufacturability and validate the thermal performance for each configuration. A comparison was made with current automotive radiator performance.

Designs were centered on current production tubes and headers as these are readily available for manufacture of prototype radiators.

The dimensions of the heat exchanger core were 3.93 inches $(100 \mathrm{~mm})$ by 3.93 inches $(100$ $\mathrm{mm})$ by 5.91 inches $(150 \mathrm{~mm})(\mathrm{LxWxH})$. After acquiring the details, the cores were assembled and braze development started. The first fabricated core and a cross section are shown in Figure 5-1. Some fabrication issues were encountered, which highlight the manufacturing differences with such a fin type. There was bowing of the top fin passage and some vertical deformation. A leak test of the core was conducted with positive results. This demonstrated successful brazing of the microchannel core.
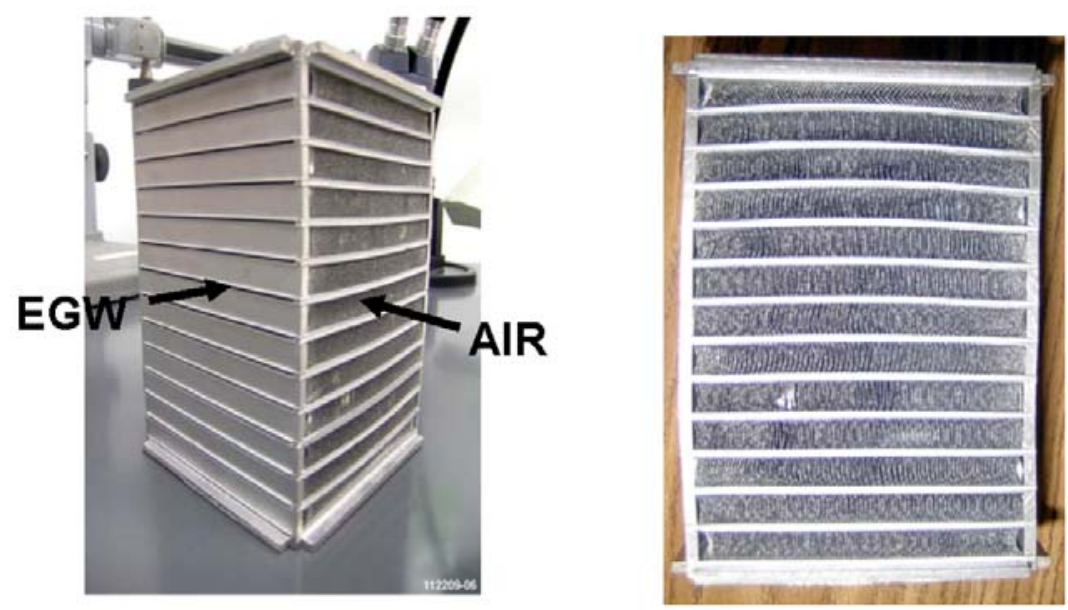

Figure 5-1. Microchannel Sub-Scale Heat Exchanger

Work was also started on building and testing an aluminum foam sub-scale heat exchanger to validate the thermal performance predictions, as well as to learn the manufacturing issues associated with this technology. Core drawings were completed and are shown in Figure 5-2. The dimensions of the heat exchanger core were 3.15 inches $(80 \mathrm{~mm})$ by 6.3 inches $(160 \mathrm{~mm})$ by 3.94 inches $(100 \mathrm{~mm})(\mathrm{LxWxH})$. Hardware procurement started and some preliminary brazing trials were conducted. 


\section{Honeywell}

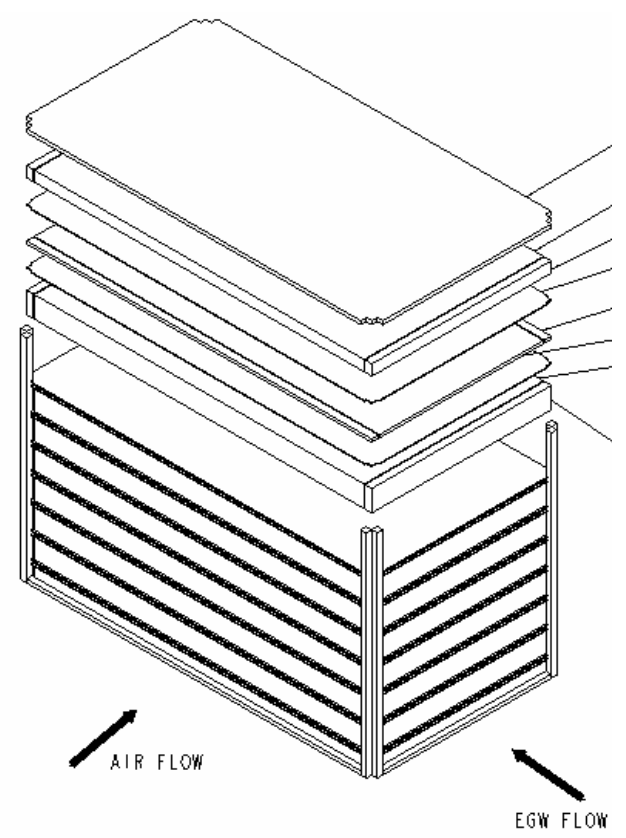

Figure 5-2. Aluminum Foam Sub-Scale Prototype

Isothermal pressure drop ( $f$ test) for the microchannel fins was measured and the results were consistent with analytical predictions that were based on laminar flow theory at low Reynolds number $(\mathrm{Re})$. The data is presented in Figure 5-3.

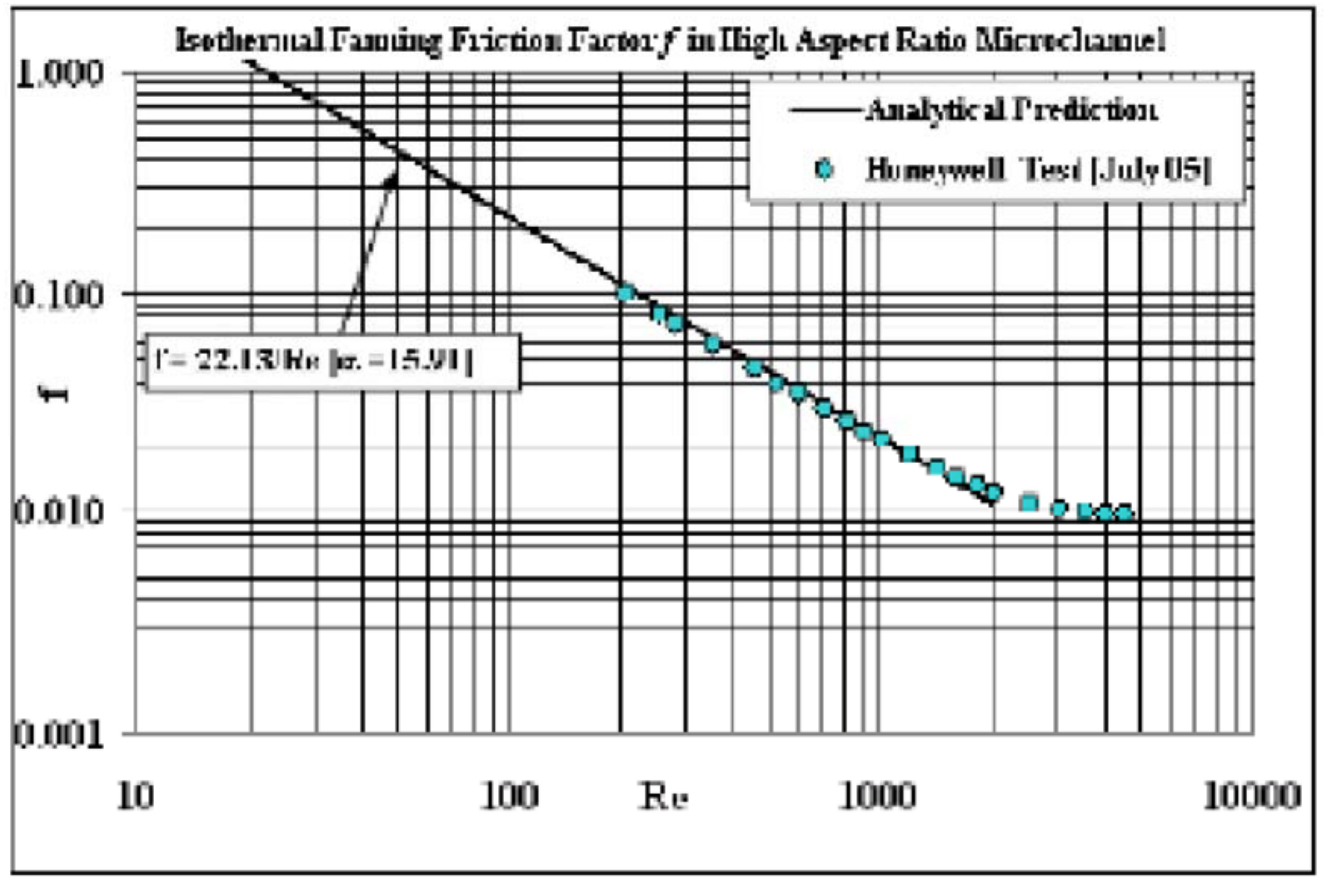

Figure 5-3. Isothermal Fanning Friction Factor $f$ in High Aspect Ration Microchannel 


\subsection{Fin Designs}

Analysis was done for standard and high-density louver, microchannel, and foam fin constructions. Fin dimensions are shown in Table 5-1.

Table 5-1. Fin Dimensions

\begin{tabular}{|l|l|l|l|}
\hline & Louver Fin & Microchannel Fin & Foam Fin \\
\hline Angle & 22 degree & Plain & N/A \\
\hline Length & 0.045 in & Plain & N/A \\
\hline Thickness & 0.004 in & 0.003 in & N/A \\
\hline Fins/inch & 18 and 24 & 40 & N/A \\
\hline Fins/inch & N/A & N/A & 20 and 40 \\
\hline Porosity & N/A & N/A & 0.89 and 0.92 \\
\hline
\end{tabular}

It should be noted that comparable characteristics could not be defined for the foam fin.

\subsubsection{Design Optimization Strategy}

The dimensions of existing production tubes were used during the analysis to ensure the best use of available performance characteristic data and to allow use of existing components in the prototype phase. The base tube measurement was 1.26 inches $(32 \mathrm{~mm})$ in the cooling air flow direction and can be used in multiple rows. One- and two-row configurations were considered.

The maximum allowed height (no flow length) was used for all calculations. The width (hot flow length) was varied to obtain different frontal areas. The cooling airflow rate was varied to obtain the required heat transfer for every case considered in the study.

\subsubsection{Value Function (VF)}

VF was established to compare various radiator designs. The VF was based on total weight for the radiator, cooling fan and motor, and additional fuel cell size required to supply the power needed to drive fan and pump motors.

VF is calculated as:

$$
\begin{aligned}
& V F=\text { radiator weight }+ \text { fan equivalent weight }+ \text { total power/0.91 } \\
& \text { where: } \\
& \text { Fan equivalent weight }=(E X P(-2.5095)) *(\Delta P \text { air * airflow })^{\wedge} 0.5442 \\
& \text { Total power }=\text { fan power }+ \text { pump power } \\
& \text { Fan power }=0.0037163^{*} \Delta P \text { air * airflow } \\
& \text { Pump power }=0.0010164{ }^{*} \Delta P \text { coolant }{ }^{*} \text { coolant flow }
\end{aligned}
$$

The optimization process sought to reduce the VF to the lowest possible value, while remaining within the set boundary conditions. 
VF was calculated for all of the fin types under consideration. The foam fin provided the best VF in the range of conditions studied. This was probably due to the increase in heat-transfer surface and improved convective heat transfer characteristics provided by the open cell foam. The fin height was varied over a range of heights within the manufacturing capability of these fins. The microchannel fin was used in this portion of the study. Fin height had only a very weak influence on VF and total power required in the range of heights considered.

Two foam geometries of $20 \mathrm{fpi}$ and 40 fpi were compared for VF, total power consumption, and radiator weight. The 40-fpi foam appeared to provide better performance than the $20 \mathrm{fpi}$.

VF was calculated for all fin sets under consideration. Comparison of VF for standard automotive, advanced automotive, microchannel, and one type of foam is shown in Figure 5-4.

Figure 1. Value Function vs. Frontal Area

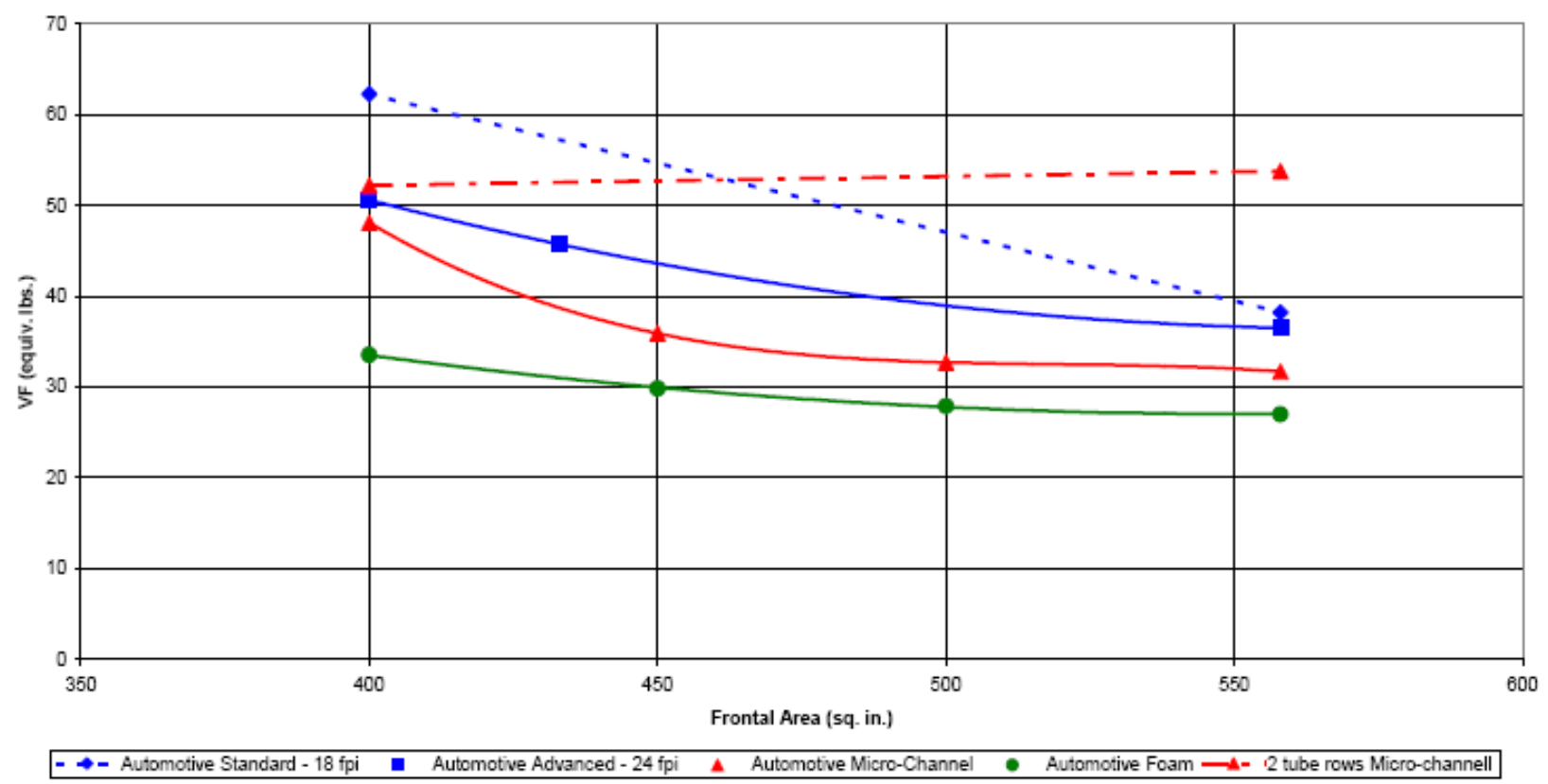

Figure 5-4. Value Function and Total Power vs. Fin Height 


\subsubsection{Fin Height Optimization}

In addition to the fin type study, analysis was made to determine the effect of fin height on radiator performance. The microchannel fin design was used for this part of the study. The fin height varied between 0.30 and 0.45 inch $(7.62$ and $11.43 \mathrm{~mm})$, which represented the fin height that was readily manufacturable. The effect of fin height on VF and total power is presented in Figure 5-5.

Figure 2. Value Function and Total Power vs. Fin Height

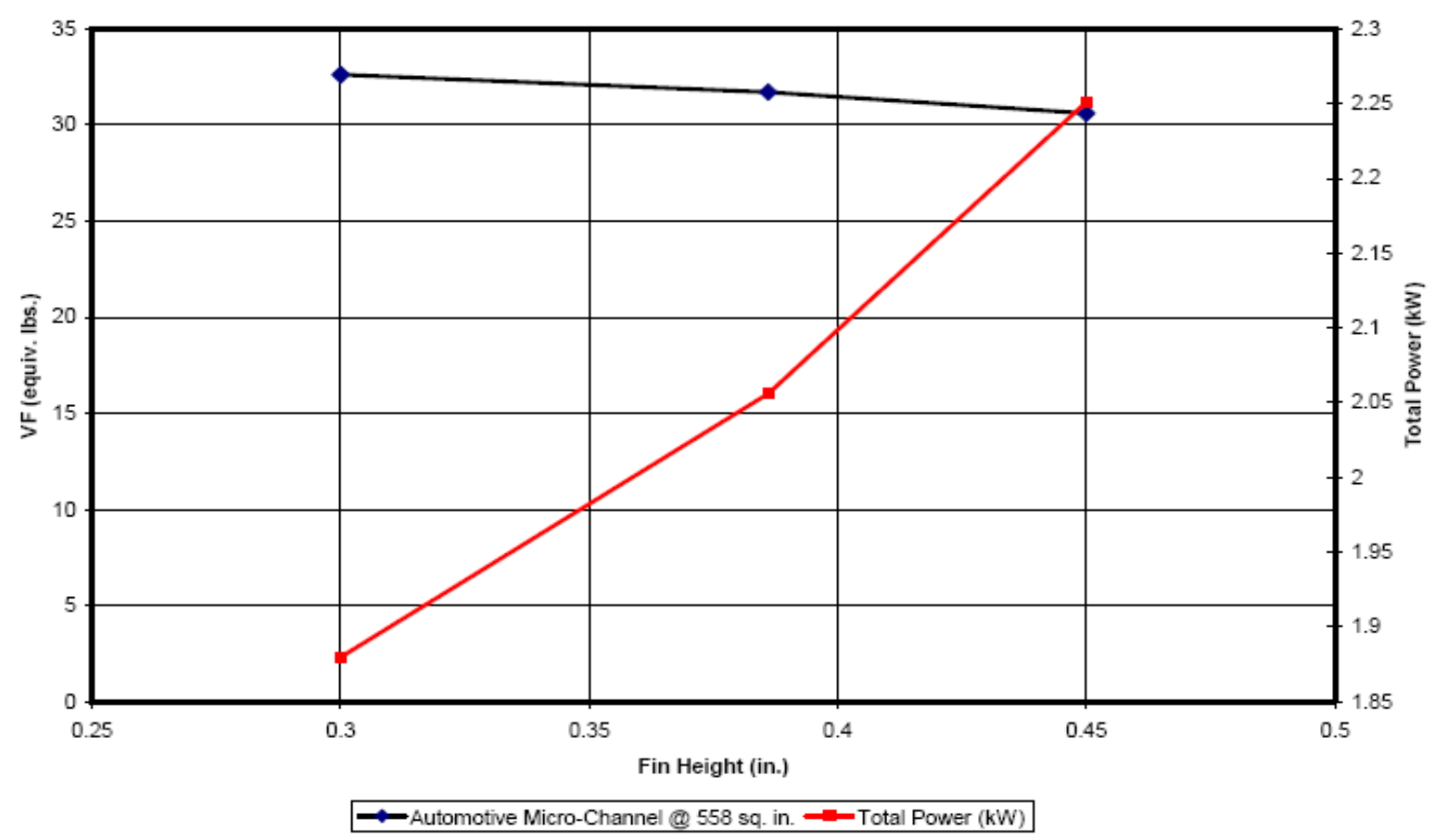

Figure 5-5. Value Function and Total Power vs. Fin Height 


\section{Honeywell}

\subsubsection{Foam Fin Optimization}

Figure 5-6 presents the foam performance with 40 fpi and 92 percent porosity. The performance for another foam type with $20 \mathrm{fpi}$ and 89 percent porosity was also calculated. For this foam type, one- and two-tube row designs were considered. This comparison is shown in Figure 5-6.

Figure 3. Foam Fin - Value Function vs. Frontal Area

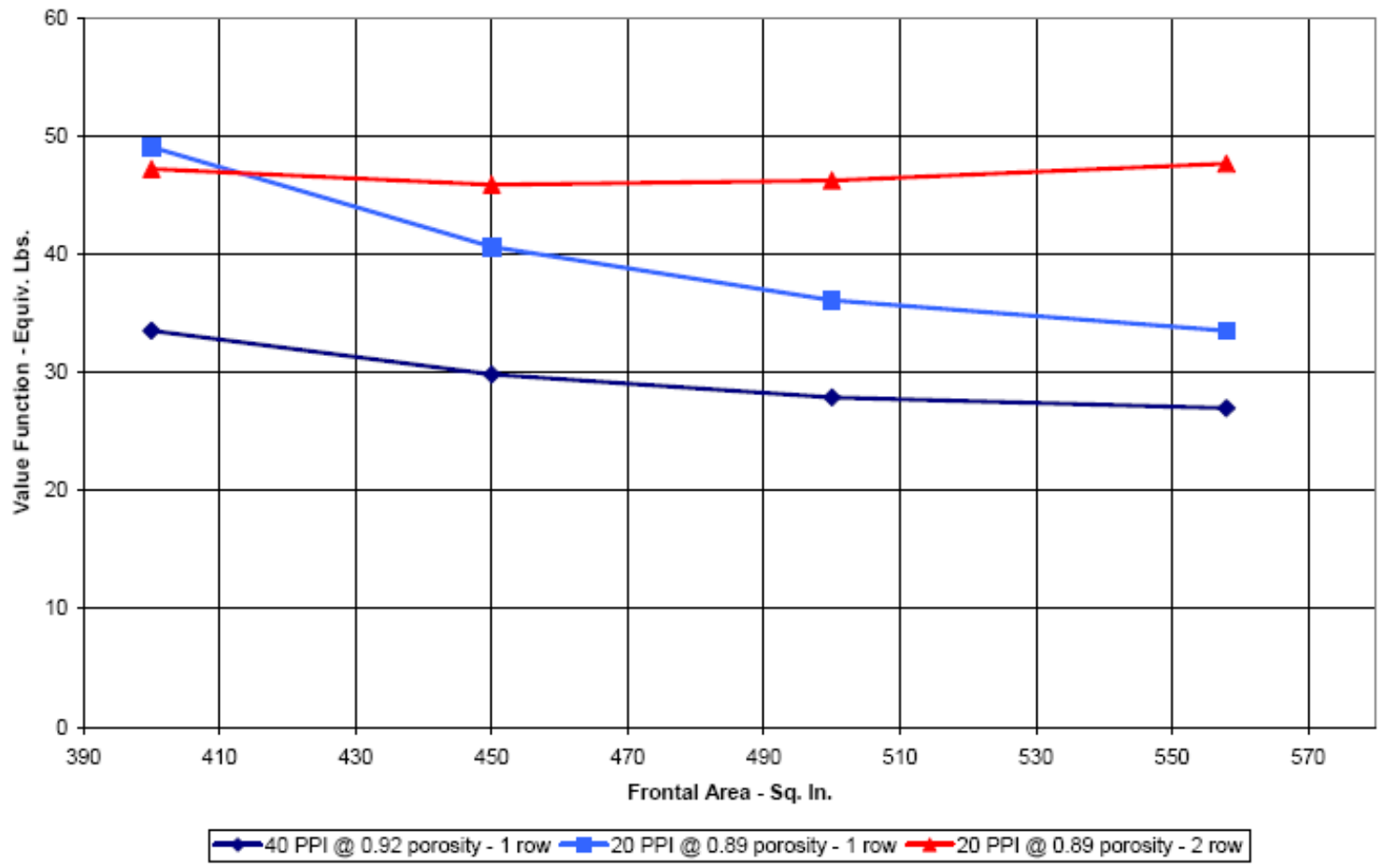

Figure 5-6. Foam Fin - Value Function vs. Frontal Area 
The 40-fpi foam had the best VF in a one-row design. The VF for the two-row core behaved in a similar manner to the two-row microchannel design. It means that VF decreases with reduced frontal area in the range studied because the radiator weight decreased faster than the increase in airflow requirement. Figure 5-7 shows that 40-fpi foam yielded a better VF and a lower total requirement than 20 -fpi foam.

Figure 4. Foam Fin - Power vs. Frontal Area

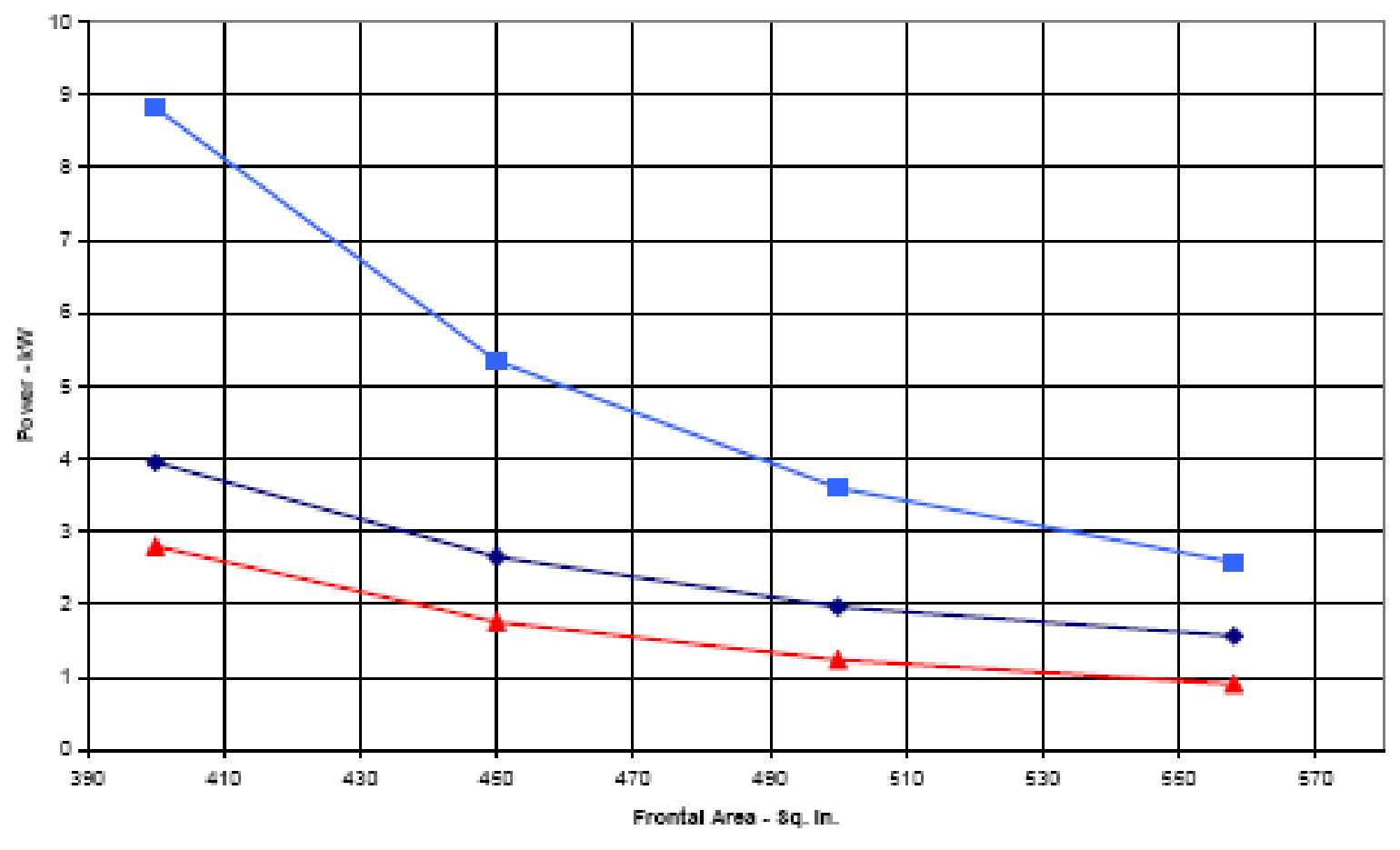

40 PFI Q 0.92 porosity - 1 row $\rightarrow$ - 20 PFI Q 0.89 porosity - 1 row -L-20 PPI Q 0.89 porosity - 2 row

Figure 5-7. Foam Fin - Power vs. Frontal Area 
The one-row 20-fpi core design was unable to meet the 60-kW heat rejection requirement with less than 2-kW total power draw, while the 40-fpi design is able to meet the requirement at core frontal areas above $500 \mathrm{sq}-\mathrm{in}(3225.8 \mathrm{sq}-\mathrm{cm})$. The 20 -fpi foam in a two-tube row configuration was able to meet the $60-\mathrm{kW}$ heat rejection requirement using less than $2-\mathrm{kW}$ power draw at core frontal areas greater than $450 \mathrm{sq}-\mathrm{in}$ (2903.2 sq-cm). There was, however, a substantial radiator weight penalty inherent in this configuration, as shown by Figure 5-8.

Figure 5. Foam Fin - Radiator Wet Weight vs. Frontal Area

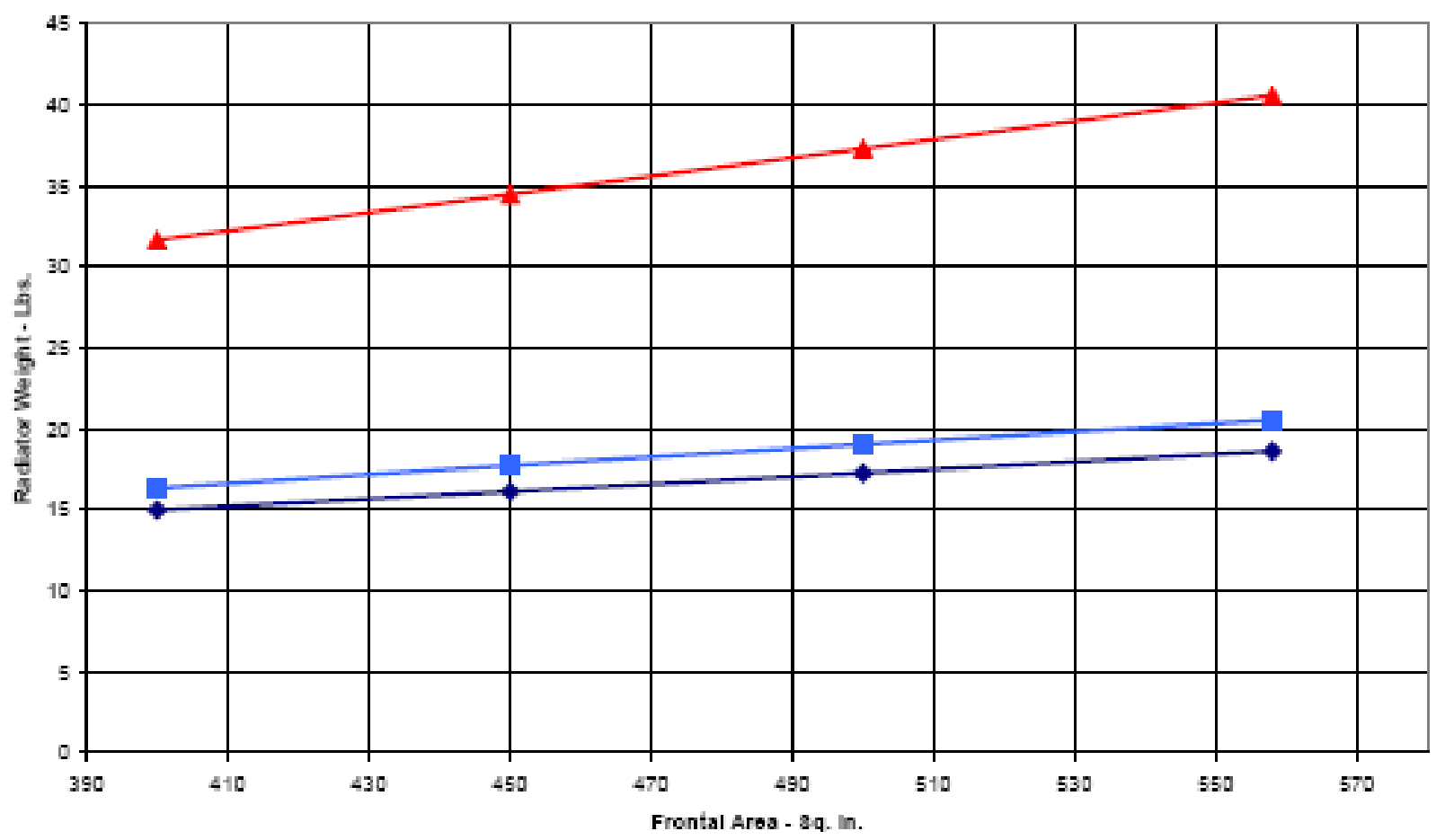

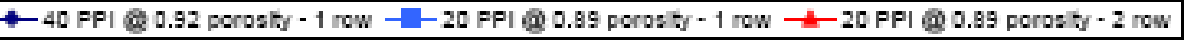

Figure 5-8. Foam Fin - Radiator Wet Weight vs. Frontal Area

A decision was made with DOE concurrence to build a prototype foam radiator to meet the program objectives. A design review was held to decide the go-forward configuration. It was decided to build two prototype radiators (foam and louver fins) for demonstration of performance of the aluminum foam with $40 \mathrm{fpi}$ and 0.92 porosity with a $558 \mathrm{sq}-\mathrm{in}(3600 \mathrm{sq}-\mathrm{cm})$ frontal area and a single row of tubes and comparison with louver fins. The readily available 356-cast aluminum foam material was used for the heat exchanger, which was suitable for brazing. The prototype foam and louver fin radiators are shown in Figure 5-9.

Honeywell acquired suitable foam material to braze a second heat exchanger. The supply base for the appropriate foam material was limited and located off-shore. A visit to the supplier was planned to ensure that requirements are clear and that the final foam configuration is compatible with Honeywell manufacturing processes. 


\section{Honeywell}

This page has been deleted because it was deemed to contain Honeywell Confidential information. 


\section{Honeywell}

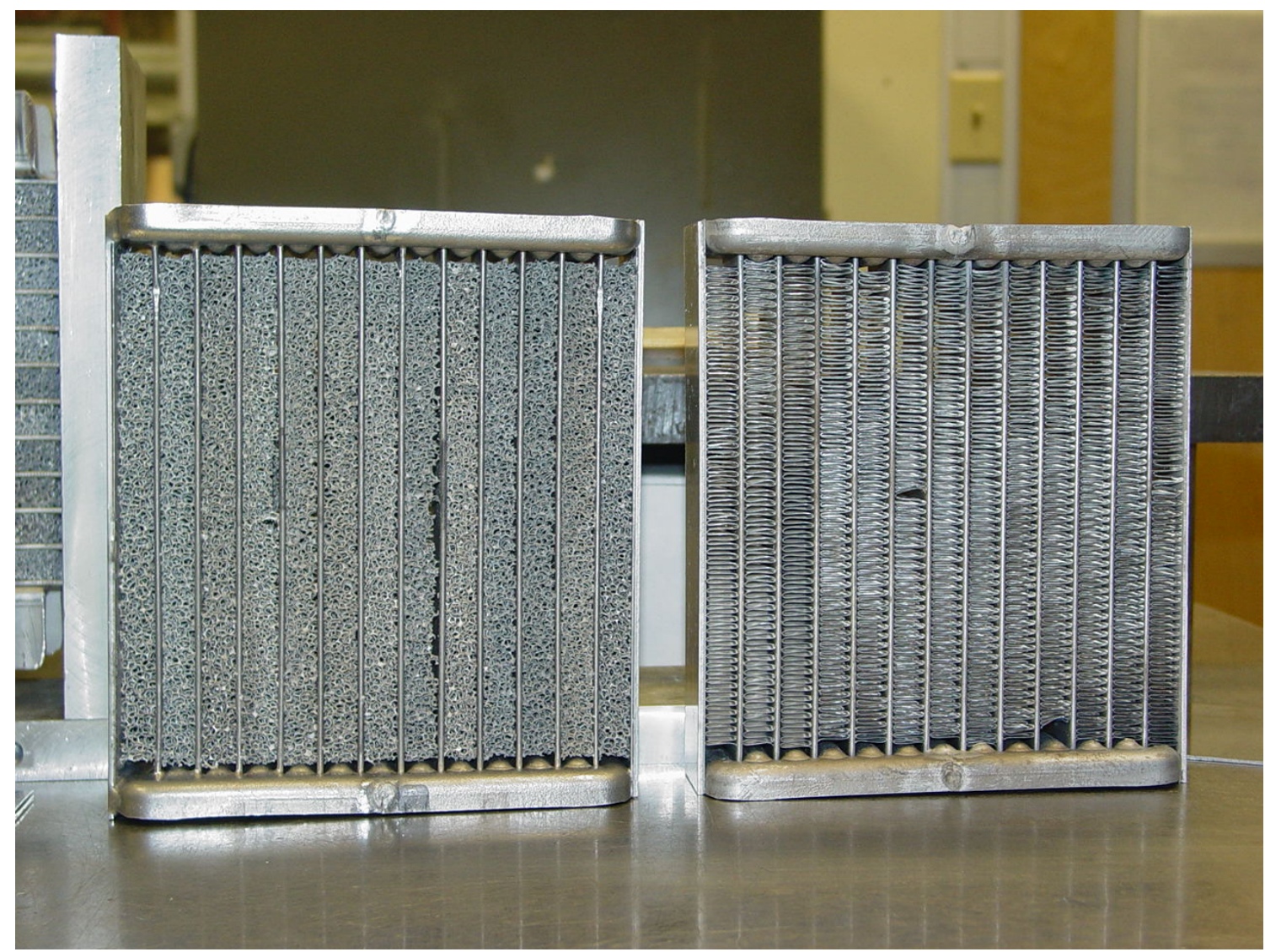

Figure 5-9. Prototype Foam and Louver Fin Heat Exchanger

Honeywell also engaged the University of Cincinnati (UoC) to evaluate and perform the computational analysis of high-performance surfaces such as wavy and offset fin surfaces for applications in fuel cell radiator application. The first task for UoC was to perform the computational modeling of forced convection in compact wavy-fin cores.

Due to their superior performance and compactness, the metallic foam radiators were being considered in a TWM system for PEM fuel cells in transportation applications. Preliminary DOE TWM radiator performance trade study suggests that the use of aluminum foam as an airside heat transfer surface results in a significant size and weight advantage relative to standard plate-fin or tube-fin radiators. However, such high performance of a foam radiator was associated with a risk of environmental fouling and contamination, which can reduce their potential performance benefit. For one-tube-row designs, the foam provided the best VF, while the standard automotive designs were considered the worst. The microchannel design was better than advanced automotive, but worse than foam. In all one-row cases, the VF increased with reduction in core frontal area because the airflow requirements increased faster than the decrease in weight. In the case of the two-row core, the VF decreased with reduced frontal area in the range studied because the weight decreased faster than the increase in airflow requirement.

The foam fins provided the best performance followed by microchannel and high-density louvered fins. The VF was not sensitive to fin height, but increased slightly as fin height was increased. The VF improved as frontal area increased for one-row cores. VF improved slightly 


\section{Honeywell}

as the core frontal area decreased for two-row cores within the range of values studied. The VF improved as core thickness decreased. The best radiator for prototype demonstration of performance improvement was the 40 fpi and 0.92 porosity foam fin with a 558 sq-in (3600 sq-cm) frontal area and a single row of tubes. This combination produced the best alternative between best VF, lowest total power consumption, and lowest radiator weight.

The aluminum foam, even though it had the best heat transfer performance, was removed from consideration for the fuel cell automotive radiator consideration. The primary reasons for this action were:

- The fouling and plugging of the aluminum foam were identified as a potential issue.

- Aluminum foam manufacturing was still not mature for radiator application. There was still the need to evaluate additional foam manufacturing processes other than the current cast process.

- Vacuum brazing with current braze filler metal may not be the proper choice. The 356cast foam material used for the radiator was unacceptable for brazing.

- The current supply base was limited to off-shore suppliers.

- Improved analytical models were needed for foam characterization and performance predictions due to non-uniformity of the material.

- Substituting foam for fins will not take advantage of performance and packaging attributes.

- Secondary operations to increase surface area contact were required. 


\section{Honeywell}

\subsection{PROGRAM ACTIVITIES DURING 2006}

The funding for the TWM program was placed on hold from the fourth quarter of 2005 to the third quarter of 2007 by DOE directive due to funding limitations. 


\subsection{PROGRAM ACTIVITIES DURING 2007}

Due to limited initial funding, Honeywell and DOE decided to focus on the thermal management portion of the program and later to add the water management work when additional funding is made available.

During the fourth quarter of 2005, prior to the program being placed on hold, the main focus for the heat exchanger work was to validate the aluminum foam and microchannel radiator performance. Engineers at ANL were working to validate the Honeywell aluminum foam predictions. Two meetings were held between ANL and Honeywell engineers to resolve discrepancies in the results and to re-evaluate the feasibility of the foam heat exchanger for automotive application. After elimination of foam heat exchanger from consideration, it was decided to evaluate 18-fpi and 24-fpi louvers and 40-fpi and 50-fpi microchannel fins.

Fuel stack radiator requirements, shown in Figure 7-1, were established based on the ANL PEM fuel cell automotive system model.

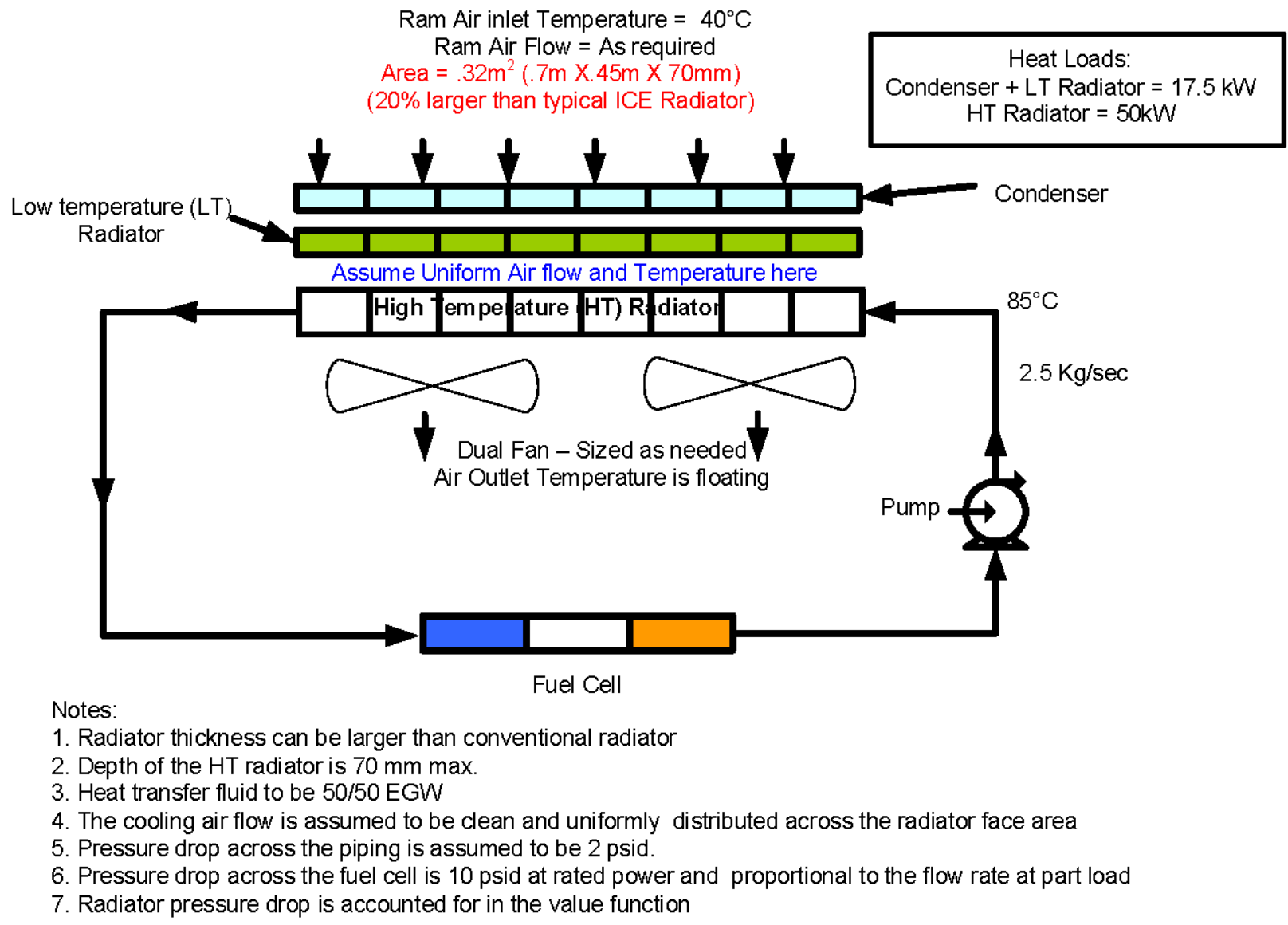

Figure 7-1. Fuel Stack Radiator Requirements 
VF was developed by ANL for the evaluation of various radiator configurations in a PEM fuel cell automobile system model. The VF and definition of variables are presented in Figure 7-2.

$$
V F=a\left(\frac{D}{F E^{*}}\right) C_{F}+\left[b C_{F C S}-c\left(\frac{D}{F E^{*}}\right) C_{F}\right]+C_{r}
$$
(I)
(II)
(III)
(IV)

I: Additional weight $->$ Lower fuel economy $\rightarrow>$ Higher fuel cost

II: Higher parasitic power $\rightarrow$ Larger fuel cell system $\rightarrow$ Higher initial cost

III: Larger stack -> Higher efficiency at part load $\rightarrow$ Lower fuel cost

IV: Thermal management system initial cost

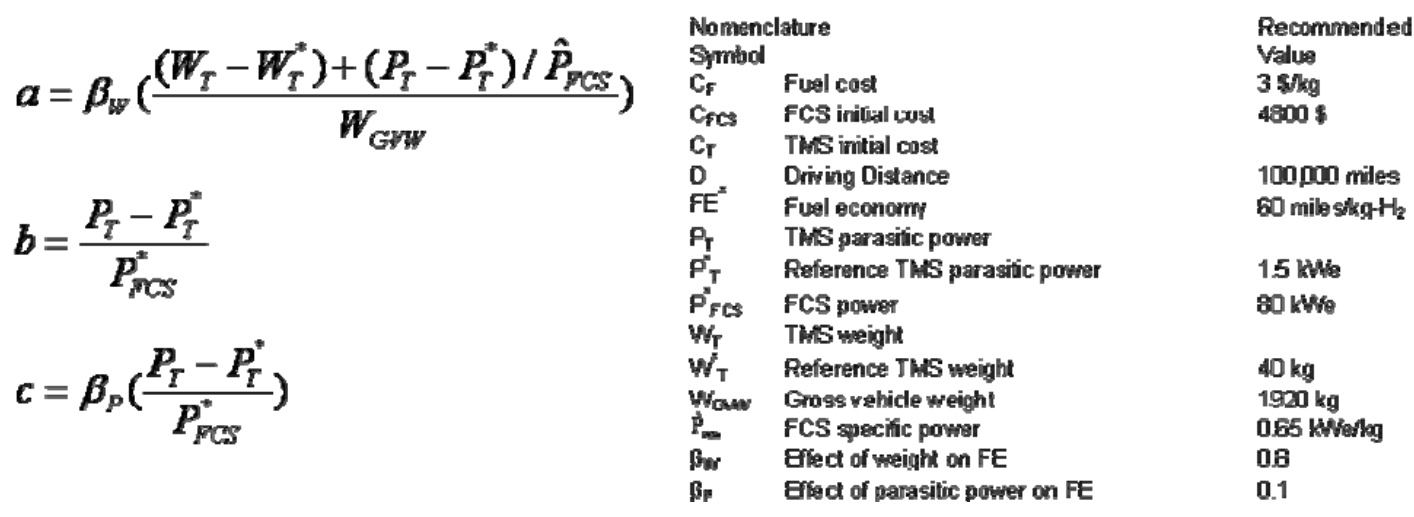

Figure 7-2. Value Function and Variables

Due to the reasons documented earlier, it was decided to drop the foam heat exchanger for further considerations of automotive application. 


\section{Honeywell}

\subsection{PROGRAM ACTIVITIES DURING 2008}

The preliminary design analysis was conducted for advanced louvered and microchannel fin configurations. The value function was used to determine the optimal solution for the potential fuel cell radiator.

A bottoms-up cost model for the radiator was completed using a production rate of 200,000 and 500,000 per year. The cost of the coolant pump and radiator fan was based on the OEM supplier catalog price.

After considering various surface configurations (offset, louver, microchannel, foam) and materials (aluminum, copper, and carbon), the following four-candidate fins were selected for further evaluation

- Microchannel $40 \mathrm{fpi}$

- Microchannel $50 \mathrm{fpi}$

- Advanced louvered fin $18 \mathrm{fpi}$

- Advanced louvered fin $24 \mathrm{fpi}$

\subsection{Sub-Scale Radiators}

Four sub-scale, 9-inch by 9-inch $(228.6 \mathrm{~mm} \times 228.6 \mathrm{~mm})$, radiators were built, one for each of the configurations, as shown in Figure 8-1, with louver fin densities of 18 fins per inch (fpi) and $24 \mathrm{fpi}$ and microchannel fin densities of $40 \mathrm{fpi}$ and $50 \mathrm{fpi}$. Each fin thickness was 0.003 in $(0.076 \mathrm{~mm})$ with a height of $0.384 \mathrm{in}(9.75 \mathrm{~mm})$.

The sub-scale radiator will help define the brazing parameters and any potential manufacturability issues and the test data will confirm the performance parameters used in the initial analytical models. The result will help revise the value comparison and determine the goforward, full-scale radiator configuration.

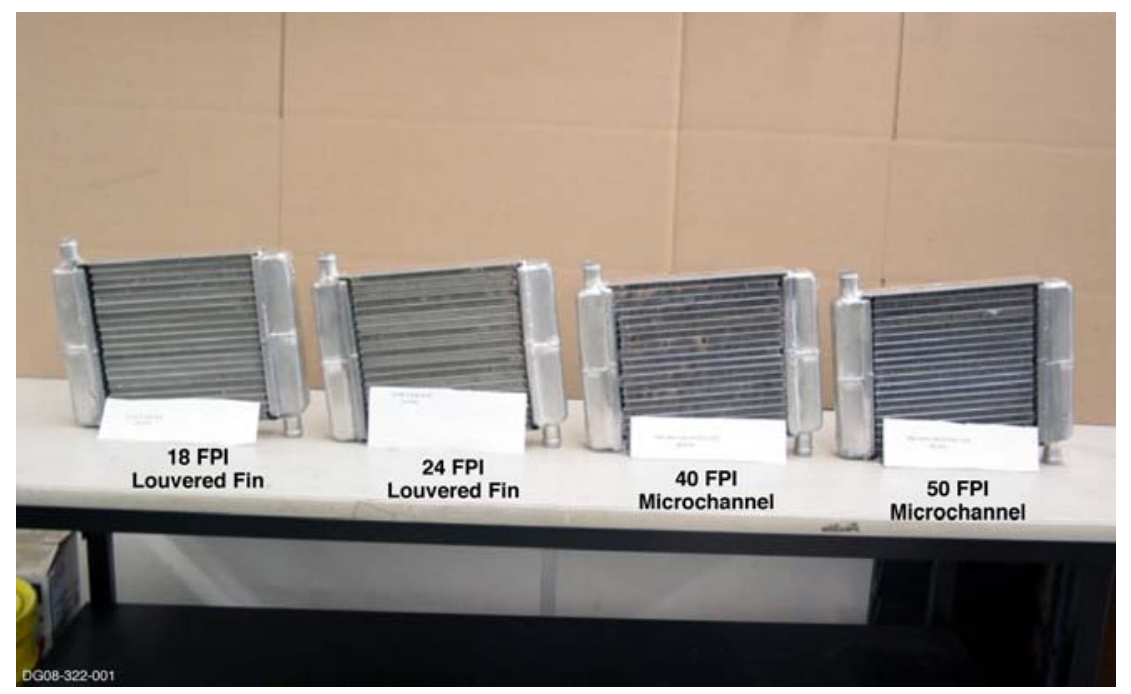

Figure 8-1. Sub-scale Radiators for Four Candidate Configurations 


\section{Honeywell}

This page has been deleted because it was deemed to contain Honeywell Confidential information. 


\section{Honeywell}

The coolant side pressure drop data was significantly higher than predicted by the model due to the location of the pressure-sensing probes. The model predicted the pressure drop for the radiator core only with the probes placed in the coolant pipes connecting to and from the radiator, thus including the pressure drop for the pipes. The coolant pressure drop is shown in Table 8-1.

The effectiveness of the 24-fpi louvered fin radiator was higher than the 18-fpi louvered fin radiator. This was in agreement with the analytical prediction. Figure 8-3 shows the comparison of effectiveness between 24-fpi and 18-fpi louvered fins. 


\section{Honeywell}

Subscale 9x9 inch 24pfi Louver Fin

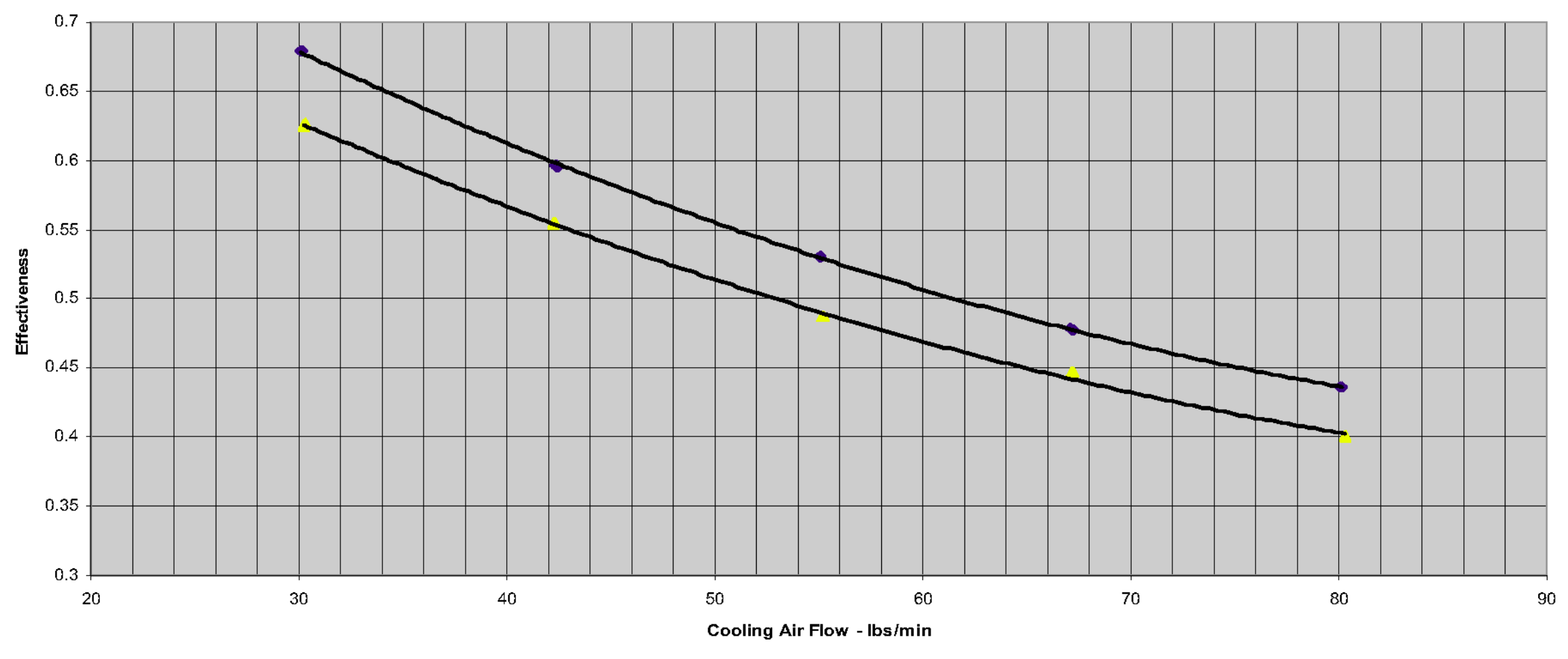

•24fpi@15.4gpm $\triangle 18 f \mathrm{fi@15.4gm}$

Figure 8-3. Louver Fin Comparison: 18 vs. 24 fpi 
The pressure drop for the 18-fpi radiator was higher than for the 24-fpi radiator. The analytical prediction was that the 18-fpi radiator would have a lower pressure drop. After further evaluating the pressure drop test data and eliminating the effect of temperature and pressure, sigma delta $P$ was plotted for various air flow rates, as shown in Figure 8-4. The data confirmed that the pressure drop in 18-fpi was lower than 24-fpi, as expected.

\section{Coolant flow of 19.4 gpm at $50 \mathrm{~kW}$ design condition}

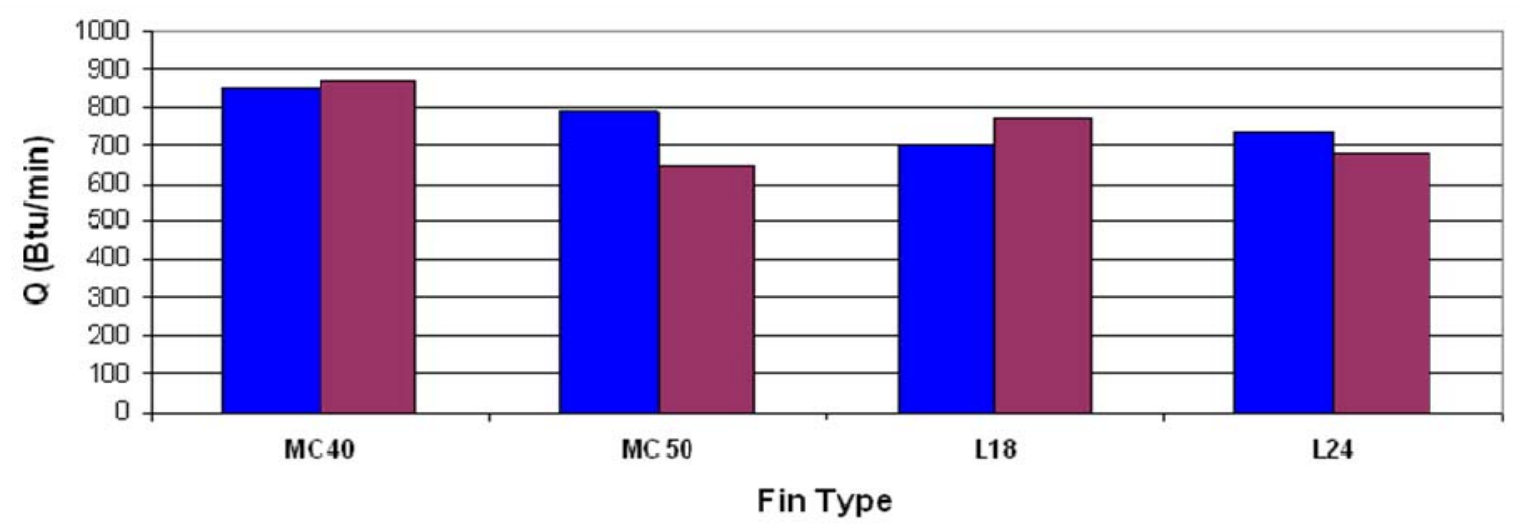

\begin{tabular}{|l|}
\hline Model $\square$ Test \\
\hline
\end{tabular}

Figure 8-4. Thermal Management Test Data vs. Predictions

The analysis showed the 50-fpi radiator had higher effectiveness than the 40-fpi. However, during the test, the 50 -fpi inlet air was $\sim 20^{\circ} \mathrm{F}$ higher than that of the 40 -fpi radiator, which affected the results. The testing of these two radiators was conducted at different ambient conditions (50-fpi radiator inlet air was $\sim 20^{\circ} \mathrm{F}$ higher than that of the 40 -fpi radiator), which skewed the test data. When the test data was corrected for the temperature difference, the results, as shown in Figure 8-5, shows that the 50-fpi microchannel had higher efficiency than the $40-$ fpi, as expected.

The test data validated the performance model predictions quite well, as shown in Figure 8-5. The 50-fpi microchannel performance was lower than predicted, which may be due to the nonuniformity of the brazed fins, bulginess, and the difference in fin crown configurations, as shown in the fin micrograph in Figure 9-2. Full-scale radiators are being fabricated and will be tested in the next quarter. 


\section{Honeywell}

Subscale Micro Fin Comparison: 40fpi vs 50fpi

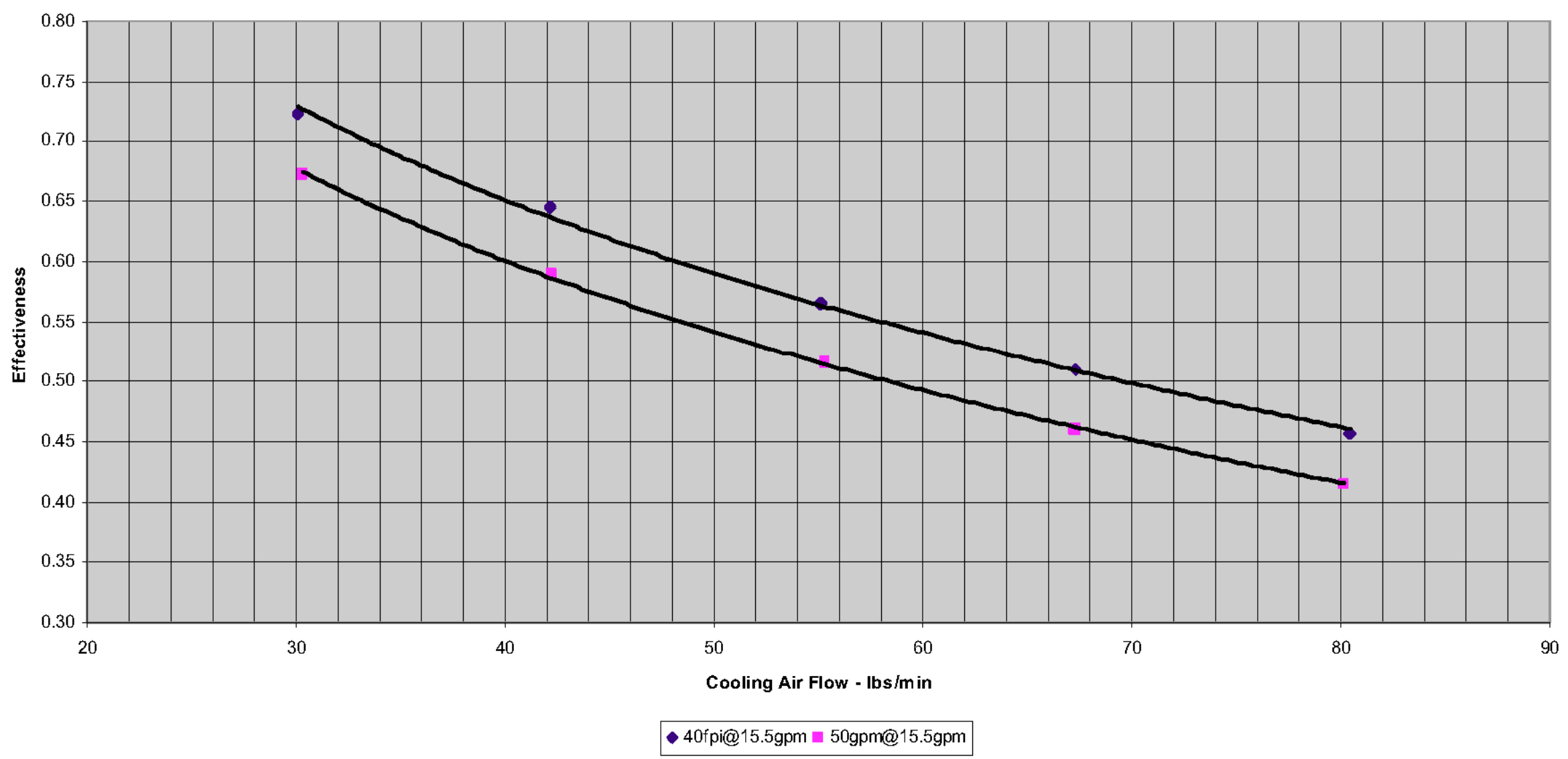

Figure 8-5. Microchannel Fin Comparison: 40 vs. 50 fpi 


\subsection{PROGRAM ACTIVITIES DURING 2009}

\section{$9.1 \quad$ Thermal Management}

The test data validated the performance model predictions quite well, as shown in Figure 9-1. The 50-fpi microchannel performance was lower than predicted, which may be due to the nonuniformity of the brazed fins, bulginess, and the difference in fin crown configurations, as shown in the fin micrograph in Figure 9-2. Full-scale radiators are being fabricated and will be tested in the next quarter.

\section{Coolant flow of $19.4 \mathrm{gpm}$ at $50 \mathrm{kWV}$ design condition}

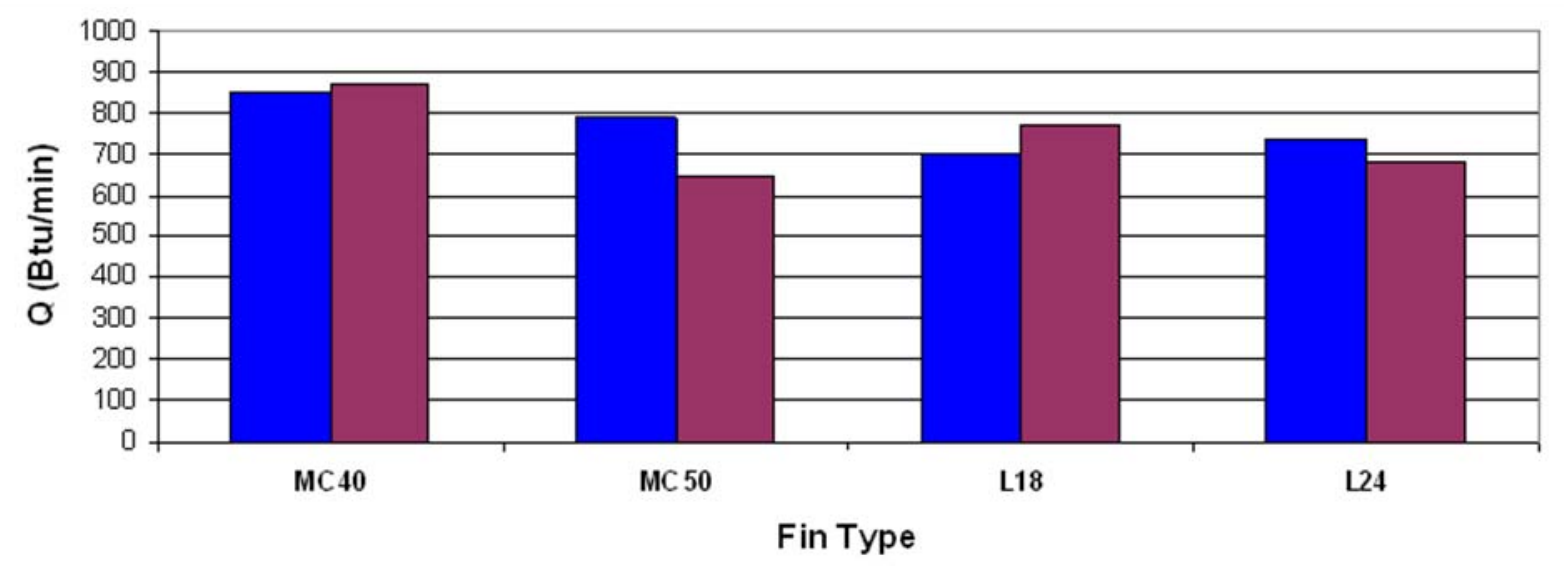

Model $\square$ Test

Figure 9-1. Thermal Management Test Data vs Predictions

A discrepancy was that the pressure drop for the 18-fpi radiator was higher than for the 24-fpi radiator. After evaluating the pressure drop test data and eliminating the effect of temperature and pressure, sigma delta $P$ was plotted for various air flow rates. The data confirmed that the pressure drop in 18-fpi is lower than 24-fpi, as expected.

The results of preliminary analysis presented in one of the quarterly reports showed that the 50fpi radiator had lower effectiveness than the 40-fpi. The testing of these two radiators was conducted at different ambient conditions (50-fpi radiator inlet air was $\sim 20^{\circ} \mathrm{F}$ higher than that of the 40-fpi radiator), which skewed the test data. When the test data was corrected for the temperature difference, the results showed that the 50-fpi had higher efficiency than the 40-fpi, as expected.

The reason for the higher pressure drop for the 40-fpi microchannel as compared to the 50-fpi could not be explained. Full-scale radiators are being fabricated and the test data for them may provide a better understanding of this discrepancy. 


\section{Honeywell}

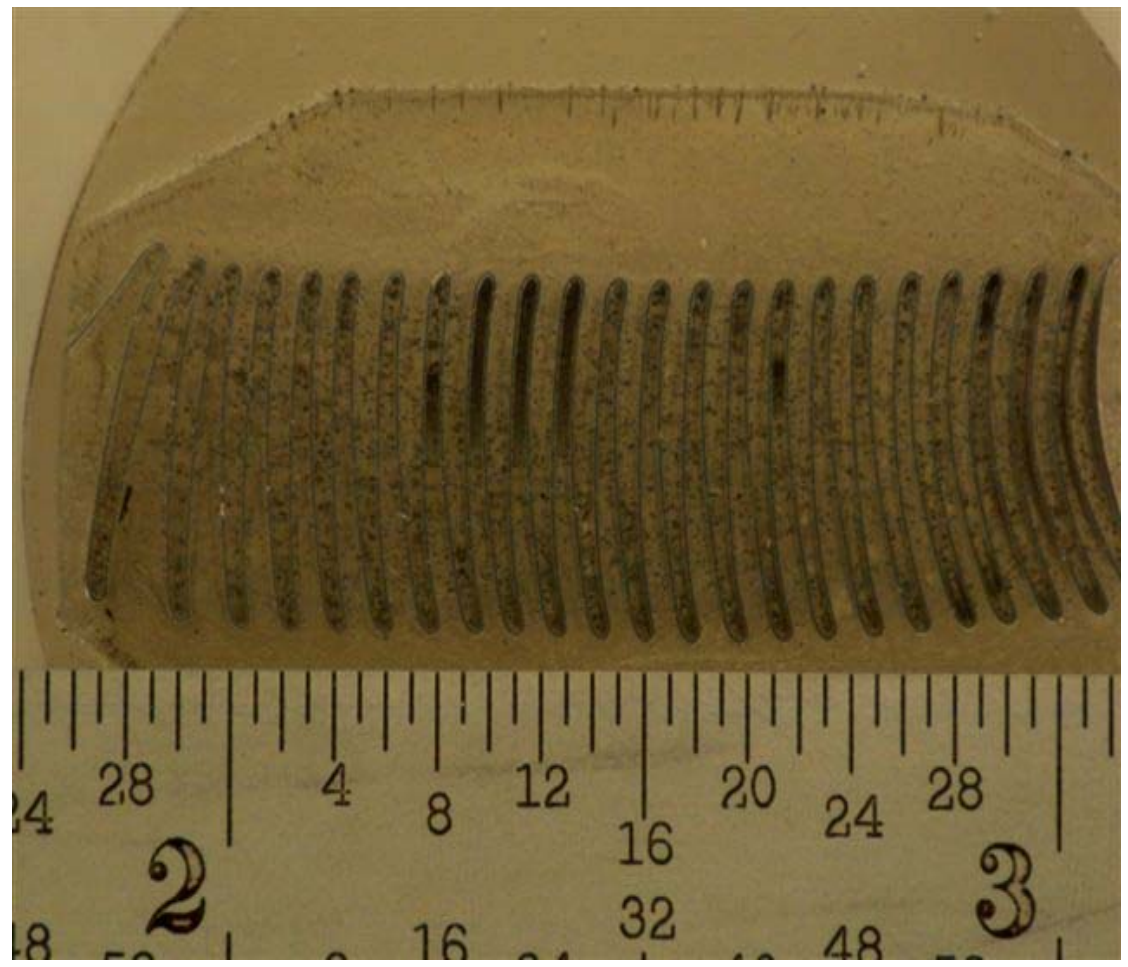

40-fpi Microchannel Fins with Round Crown

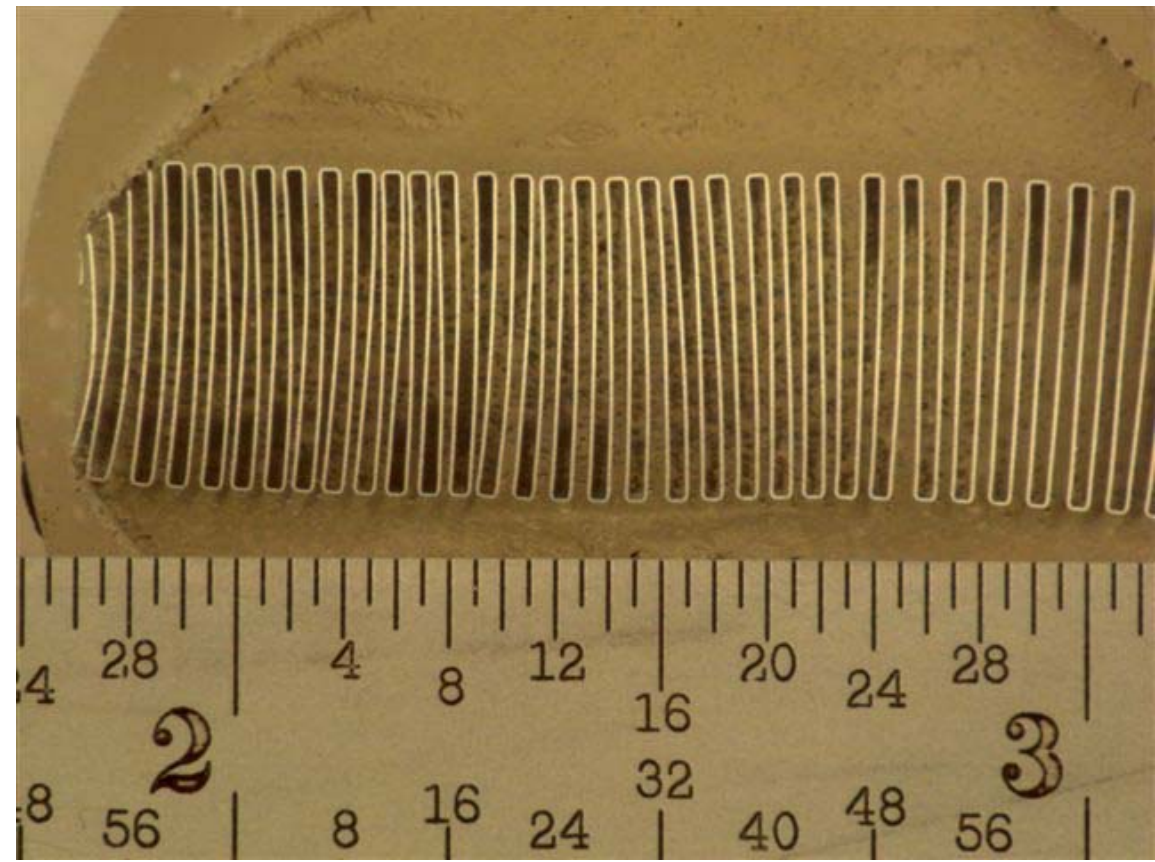

50-fpi Microchannel Fins with Square Crown

Figure 9-2. Fin Micrograph Showing Differences Between 40-fpi and 50-fpi Configurations 


\section{Honeywell}

The cost data for the coolant pump and the radiator fan was obtained from the suppliers. The value function comparison of the four fin geometries was revised using the test results and latest cost data for a pump and fan. The 40-fpi microchannel fins and 18 fpi louvered fins had a better value for the overall performance of the radiators (Figure 9-3).

The cost data for the full-scale radiator with louver and microchannel fins as a function of core thickness is provided in Figure 9-4. The louver fin radiators cost was lower than the microchannel radiators due to the weight of the fins, which is a primary cost driver.

Honeywell is planning to build and test two full-scale radiators: one with 18-fpi louver fins and a microchannel radiator with 40-fpi fins.

Pictures of full-scale radiators with 18-fpi louver and 40-fpi microchannel fins, respectively, are shown in Figure 9-10 and Figure 9-11.

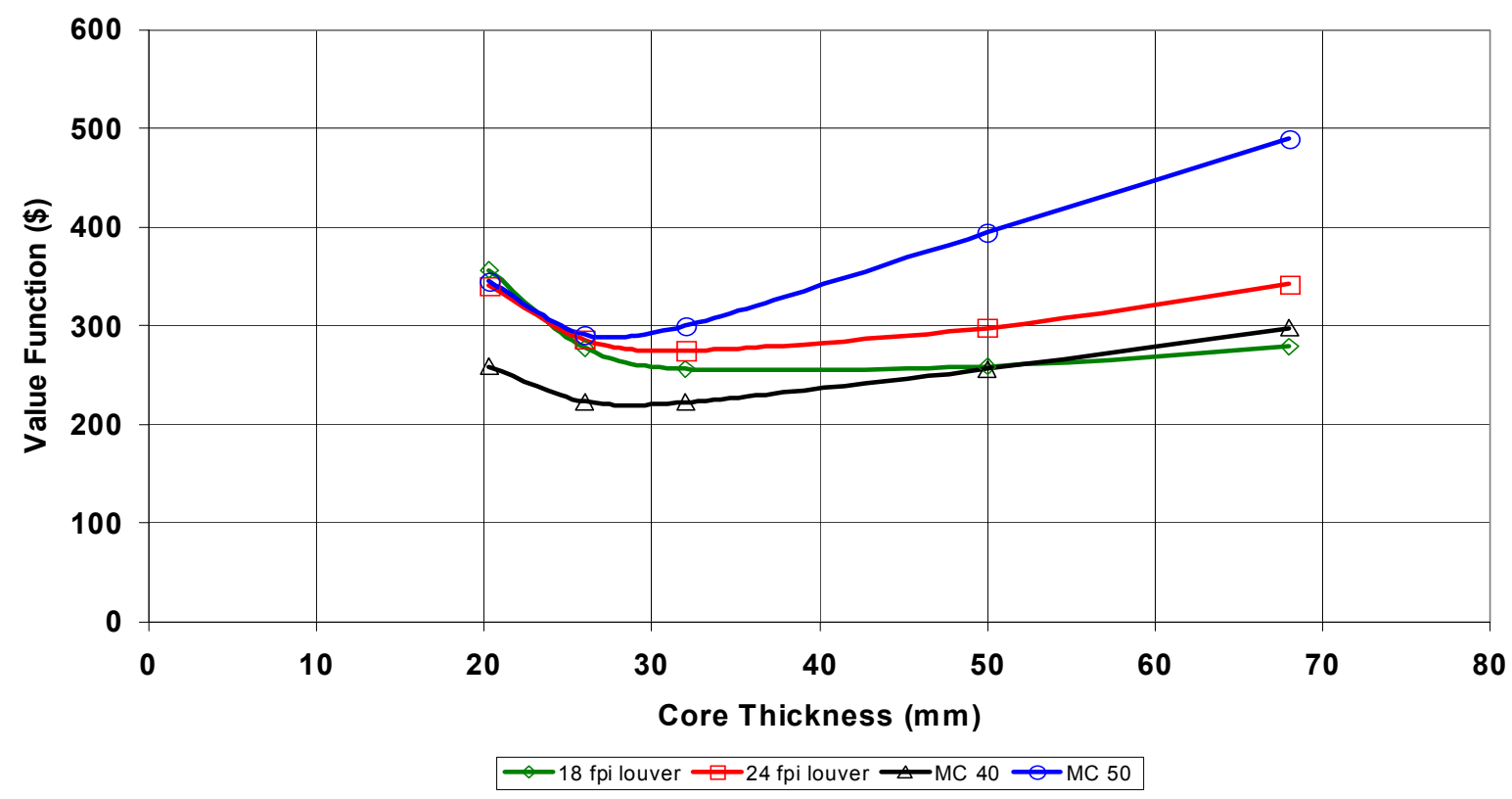

Figure 9-3. Value Function Comparison 


\section{Honeywell}

This page has been deleted because it was deemed to contain Honeywell Confidential information. 


\section{Final Value Function Comparison}

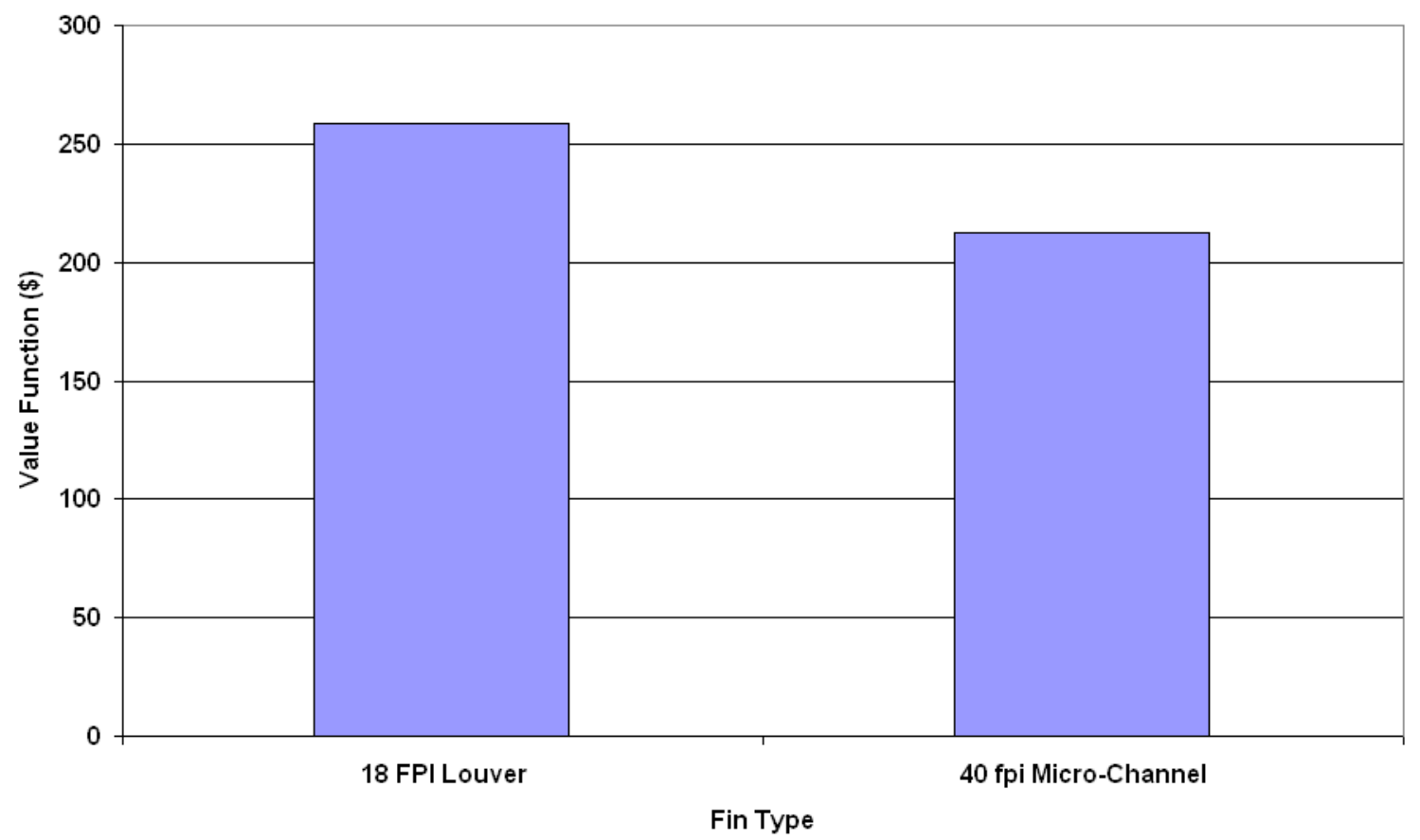

Figure 9-5. Final Value Function Comparison

The cost of the four fin radiator configurations and different core thicknesses is presented in Figure 9-6. The figure includes the cooling system cost for various core thicknesses. The cooling system includes radiator, coolant pump, radiator fan, and miscellaneous hoses, clamps, etc. The data showed that the 18-fpi louver radiator was the optimum configuration for this application. TIAX LLC of Cambridge MA has estimated the cost of a full-scale radiator for the PEM Fuel Cell Automobile was $\$ 56$ based on a ground-up estimate and data provided by Modine radiator manufacturer. The bare cost did not include any markup or profit. Honeywell cost estimated for louver and microchannel fin radiator was $\$ 44$ and $\$ 52$ respectively, as shown in Figure 9-6. 


\section{Honeywell}

This page has been deleted because it was deemed to contain Honeywell Confidential information. 


\section{Honeywell}

this tank then moved up through a series of baffles and a water shower before leaving the tank. The air picked up moisture from the shower inside the tank. The air was then heated and the humidity measured before it entered the UUT at Point 3 . The humidity of the air leaving the UUT (Point 4) was measured before the air was exhausted overboard. The test stand in its existing configuration had two main problems: 1) no secondary method was available to validate the humidity measurements and mass balance calculation; 2) precise control of the humidity level entering the UUT on the wet side was impossible. Both of these concerns were addressed by moving away from the current humidification method of showering water inside a tank. Figure 9-8 shows the revised test stand schematic.

To address the first concern, the air entering the wet side of the UUT (Point 3 ) will be humidified by injecting steam into the air stream. The first step in this process is to measure the humidity of the dry air stream using a chilled mirror. The amount of liquid water to achieve the desired absolute humidity level at the UUT (Point 3) can then be calculated and added to the boiler to be completely converted into steam. The steam is then injected into the air stream and introduced into the UUT (Point 3). The combination of the existing air stream humidity plus the added steam equals the desired absolute humidity at the UUT (Point 3). A mass balance can then be calculated using humidity measurements at the three other UUT ports (Points 1, 2, and 3 ). This humidification method is more reliable and accurate than the previous approach because the humidity calculation relies on the humidity measurement of the dry air line, the measurement of the liquid water flow, and the pressure and temperature measurement of the air entering the UUT at Point 3. Honeywell has extensive experience measuring the lower humidity levels present in the dry air line, the liquid water flow to the boiler, and the pressure and temperature required at UUT Point 3 . This method also provides a known humidity level at UUT Point 3 with which to compare the other humidity measurements. This will improve troubleshooting of the hygrometers at the higher humidity levels and lead to a more accurate mass balance.

The second concern is also addressed by introducing the steam injection method of humidification. The practice of humidifying the air using a water shower is difficult to control. Varying the flow of water to the shower nozzle impacts the humidity of the air in the tank in a way that is difficult to predict. The water in the tank is recirculated and not all of the water pumped to the nozzle is picked up by the air. Therefore, a calculation cannot be performed to predict what the humidity should be and to serve as a check to the hygrometer reading. One must rely solely on the hygrometer measurement to determine the humidity at the UUT inlet Point 3. Using steam injection, the inlet humidity level can be reliably calculated and precisely varied over the required range by controlling liquid water flow into the boiler. This calculated humidity level is used as a known starting point for the mass balance calculation. Honeywell uses this method of steam injection to supply humidified air to many other on-site tests.

Checkout of the water management test stand is continuing. Three of the 24 test points have been completed on the full-scale membrane module. Water balance calculations on these test runs revealed that only a 50-percent water mass balance was achieved. The team identified two likely causes of the poor water balance:

- Water condensation inside the test article or test-stand ducting

- Low steam temperature $\left(\sim 300^{\circ} \mathrm{F}\left[149^{\circ} \mathrm{C}\right]\right.$ at the injection point)

Water condensation is a major problem because the humidity sensors will not detect the liquid water that may be present on the duct wall. This liquid water will not be included in the water 


\section{Honeywell}

balance calculations; therefore, an accurate measurement of water transferred across the membrane cannot be determined. Drains were installed at six locations on the test stand to determine if liquid water is present in the test article or the ducting during testing. Subsequent runs confirmed the presence of liquid water upstream and downstream of the test article. Additional insulation has been added to the test stand ducting to ensure that duct wall temperatures do not fall below the dew point of the water vapor/air mixture.

Low steam temperature at the injection point may be an indication that condensed water is present in addition to the water vapor. Honeywell's best practice dictates that steam temperatures at the injection point should not fall much below $500^{\circ} \mathrm{F}\left(260^{\circ} \mathrm{C}\right)$. High steam bulk temperature ensures that all moisture is in vapor form when injected into the system. Honeywell has doubled the insulation thickness on the steam line and has observed steam temperatures of $488^{\circ} \mathrm{F}\left(253^{\circ} \mathrm{C}\right)$ and greater.

Additional test points have been run and water balance has improved to above 70 percent. The team is performing additional checks and improvements to increase this number even further. Additional work will focus on improving humidity sampling methods for the chilled mirror sensor, detecting leaks in the ducting or steam line, and improving the high humidity measurement at the membrane module outlets.

In addition, the high-humidity level air stream becomes achievable with the steam injection method. With the water-spray method, the low efficiency of the moisture pick-up rate prevents the air stream from reaching a high-humidity level. However, the steam injection method directly mixes the air stream with water vapor (steam), resulting in a more controllable highhumidity level. 


\section{Honeywell}

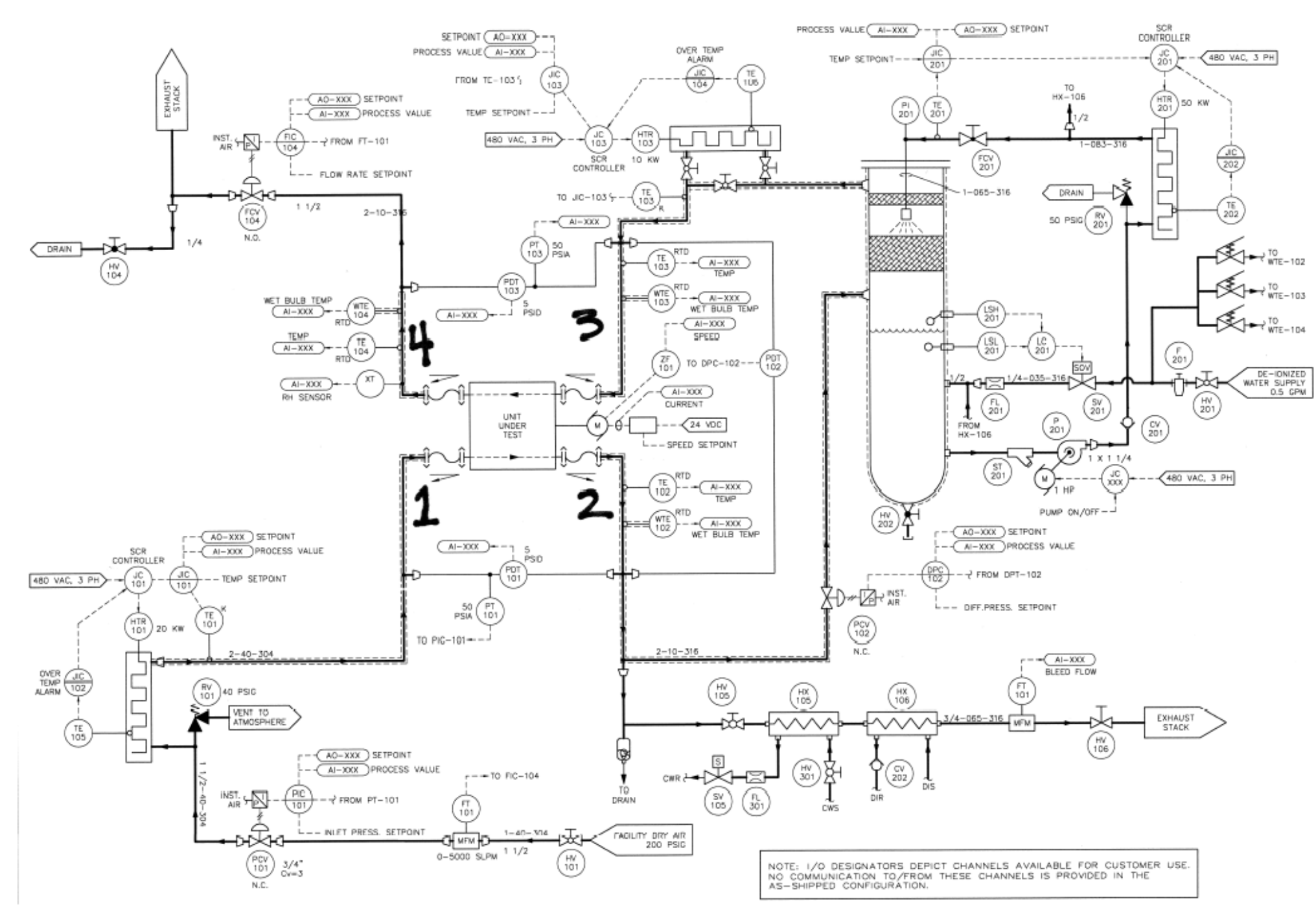

Figure 9-7. Current Test Stand Schematic 


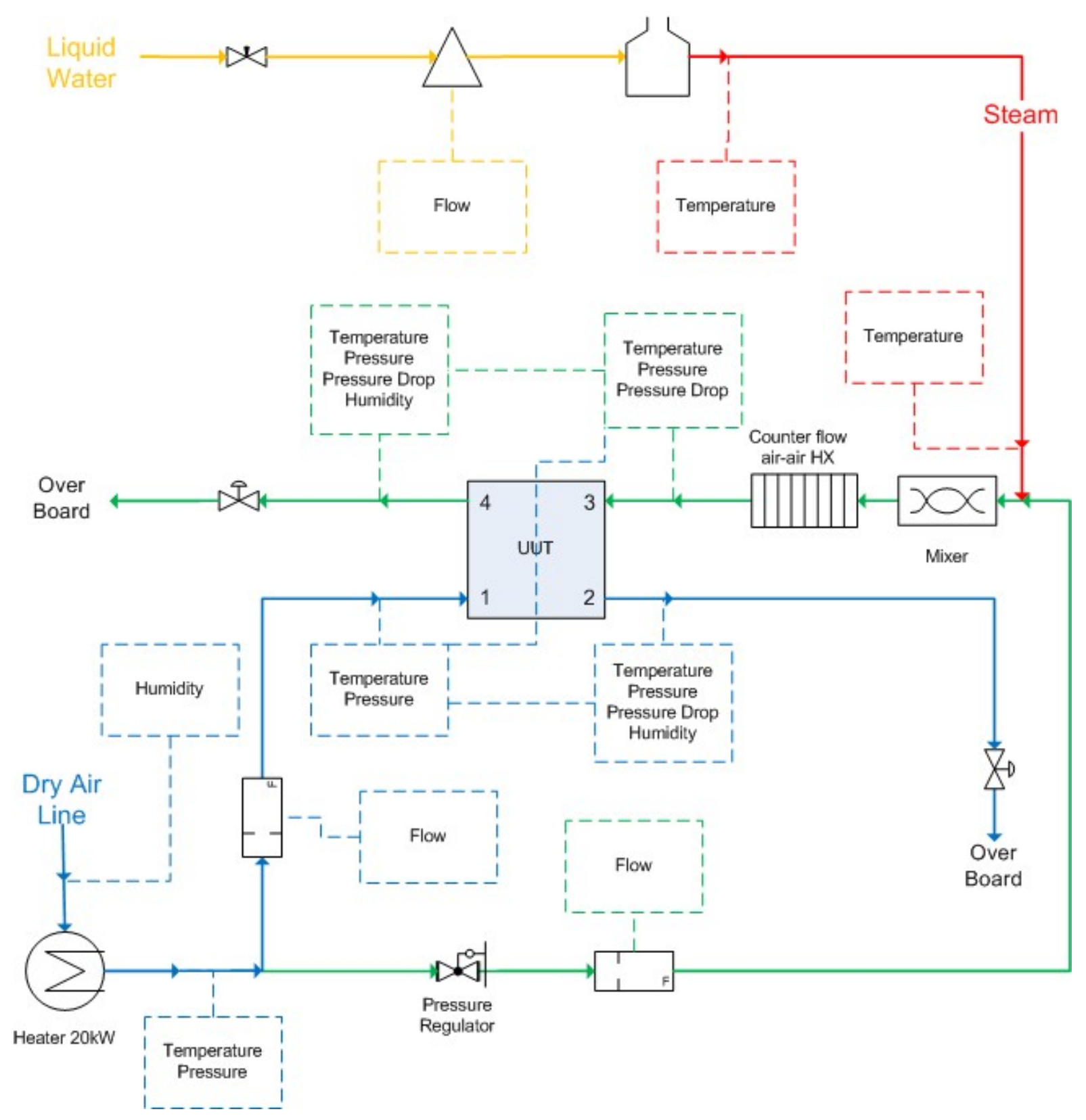

Figure 9-8. Revised Test Stand Schematic

\subsection{Proposed Test Points}

Conditioning the UUT inlet (Point 3) to 95 percent relative humidity has proven difficult in previous testing and may not be required to achieve the required 60 percent relative humidity at the UUT outlet to the fuel cell (Point 2). Therefore, Honeywell will determine the highest inlet humidity that can be reliably created by the revised test stand during the initial test stand checkout. The eight test points used in the 2008 testing will be repeated, each at three different 
inlet humidity levels for a total of 24 test points. The proposed test points are shown in Table 9-1. Honeywell welcomes any comments regarding the proposed test points.

Table 9-1. Proposed Humidification Test Points

\begin{tabular}{|c|c|c|c|c|c|c|c|c|}
\hline \multirow{3}{*}{ Case } & \multicolumn{4}{|c|}{ Wet In (3) } & \multicolumn{3}{|c|}{ Dry In (1) } & \multirow[b]{2}{*}{$\begin{array}{c}\Delta P \\
\text { (Dry-Wet) }\end{array}$} \\
\hline & \multirow{2}{*}{$\begin{array}{l}\text { Air Flow } \\
\text { rate } \\
\text { lb/min } \\
\text { (kg/min) }\end{array}$} & \multirow{2}{*}{$\begin{array}{c}\text { Dry } \\
\text { Bulb } \\
\text { Temp } \\
{ }^{\circ} \mathrm{F}\left({ }^{\circ} \mathrm{C}\right)\end{array}$} & \multirow{2}{*}{$\begin{array}{c}\text { Air } \\
\text { Pressure } \\
\text { psia } \\
\text { (kPa) }\end{array}$} & \multirow{2}{*}{$\begin{array}{c}\text { Relative } \\
\text { Humidity } \\
\quad \%\end{array}$} & \multirow{2}{*}{$\begin{array}{l}\text { Air Flow } \\
\text { rate } \\
\text { lb/min } \\
\text { (kg/min) }\end{array}$} & \multirow{2}{*}{$\begin{array}{c}\text { Air } \\
\text { Flow } \\
\text { Temp } \\
{ }^{\circ} \mathrm{F} \\
\left({ }^{\circ} \mathrm{C}\right)\end{array}$} & \multirow{2}{*}{$\begin{array}{c}\text { Air } \\
\text { Pressure } \\
\text { psia } \\
\text { (kPa) }\end{array}$} & \\
\hline & & & & & & & & psi (kPa) \\
\hline \multirow{3}{*}{1} & \multirow{3}{*}{$\begin{array}{l}10.86 \\
(4.93)\end{array}$} & \multirow{12}{*}{$\begin{array}{l}176 \\
(80)\end{array}$} & \multirow{3}{*}{$\begin{array}{c}33.75 \\
(232.70)\end{array}$} & TBD & \multirow{3}{*}{$\begin{array}{l}12.05 \\
(5.47)\end{array}$} & \multirow{12}{*}{$\begin{array}{l}157 \\
(69)\end{array}$} & \multirow{3}{*}{$\begin{array}{c}36.75 \\
(253.38)\end{array}$} & \multirow{3}{*}{$\begin{array}{c}3.00 \\
(20.68)\end{array}$} \\
\hline & & & & TBD & & & & \\
\hline & & & & TBD & & & & \\
\hline \multirow{3}{*}{2} & \multirow{3}{*}{$\begin{array}{c}7.81 \\
(3.54)\end{array}$} & & \multirow{3}{*}{$\begin{array}{c}27.20 \\
(187.54)\end{array}$} & TBD & \multirow{3}{*}{$\begin{array}{c}8.61 \\
(3.91)\end{array}$} & & \multirow{3}{*}{$\begin{array}{c}29.40 \\
(202.71)\end{array}$} & \multirow{3}{*}{$\begin{array}{c}2.20 \\
(15.17)\end{array}$} \\
\hline & & & & TBD & & & & \\
\hline & & & & TBD & & & & \\
\hline \multirow{3}{*}{3} & \multirow{3}{*}{$\begin{array}{c}2.25 \\
(1.02)\end{array}$} & & \multirow{3}{*}{$\begin{array}{c}18.51 \\
(127.62)\end{array}$} & TBD & \multirow{3}{*}{$\begin{array}{c}2.52 \\
(1.14)\end{array}$} & & \multirow{3}{*}{$\begin{array}{c}19.11 \\
(131.76)\end{array}$} & \multirow{3}{*}{$\begin{array}{c}0.60 \\
(4.14)\end{array}$} \\
\hline & & & & TBD & & & & \\
\hline & & & & TBD & & & & \\
\hline \multirow{3}{*}{4} & & & & TBD & & & & \\
\hline & $\begin{array}{c}0.93 \\
(0.42)\end{array}$ & & $\begin{array}{c}15.87 \\
(10942)\end{array}$ & TBD & $\begin{array}{c}0.93 \\
(0.42)\end{array}$ & & $\begin{array}{c}16.17 \\
(11149)\end{array}$ & $\begin{array}{c}0.30 \\
(207)\end{array}$ \\
\hline & & & & TBD & & & & \\
\hline & & & & TBD & & & & \\
\hline 5 & 10.86 & & $\begin{array}{c}33.15 \\
(23270\end{array}$ & TBD & $\begin{array}{l}12.05 \\
(5.17)\end{array}$ & & $\begin{array}{c}36.15 \\
(253.38\end{array}$ & $\begin{array}{c}3.00 \\
(2068)\end{array}$ \\
\hline & & & & TBD & & & & \\
\hline & & & & TBD & & & & \\
\hline 6 & $\begin{array}{c}7.81 \\
(354)\end{array}$ & & $\begin{array}{c}27.20 \\
(18754)\end{array}$ & TBD & $\begin{array}{c}8.61 \\
(3.91)\end{array}$ & & $\begin{array}{c}29.40 \\
(20271)\end{array}$ & $\begin{array}{c}2.20 \\
(15.17)\end{array}$ \\
\hline & & $\begin{array}{l}154 \\
(90)\end{array}$ & & TBD & & (81) & & \\
\hline & & & & TBD & & & & \\
\hline 7 & $\begin{array}{c}2.25 \\
(102)\end{array}$ & & $\begin{array}{c}18.51 \\
(12762)\end{array}$ & TBD & $\begin{array}{c}2.52 \\
(114)\end{array}$ & & $\begin{array}{c}19.11 \\
(13176)\end{array}$ & $\begin{array}{l}0.60 \\
(4.14)\end{array}$ \\
\hline & & & & TBD & & & & \\
\hline 8 & $\begin{array}{c}0.93 \\
(0.42)\end{array}$ & & $\begin{array}{c}15.87 \\
(109.42)\end{array}$ & TBD & $\begin{array}{c}0.93 \\
(0.42)\end{array}$ & & $\begin{array}{c}16.17 \\
(111.49)\end{array}$ & $\begin{array}{c}0.30 \\
(2.07)\end{array}$ \\
\hline
\end{tabular}

\subsection{Planar Membrane}

Honeywell is working closely with ANL to evaluate humidification devices based on planar membrane design. One of the manufacturers of planar membrane systems identified is dPoint Technologies, Vancouver, Canada. Most of their current prototype units are built for lowerwattage fuel cells and their upper operating temperature limit is $176{ }^{\circ} \mathrm{F}\left(80{ }^{\circ} \mathrm{C}\right)$, which is low for current PEM fuel cell applications.

After surveying the manufacturers of humidification devices with planar membranes, one supplier has been identified who can build a unit which will meet fuel cell humidification requirements. The rectangular shape of the unit will be beneficial for packaging and installation in the automobile. The production cost of the unit may also be lower as compared to Nafionbased membrane module due to the availability of a wide variety of membrane sheeting 


\section{Honeywell}

material. A representative picture of the planar membrane module is shown in Figure 9-9. A fullscale unit is being designed by the supplier and will be tested at Honeywell.

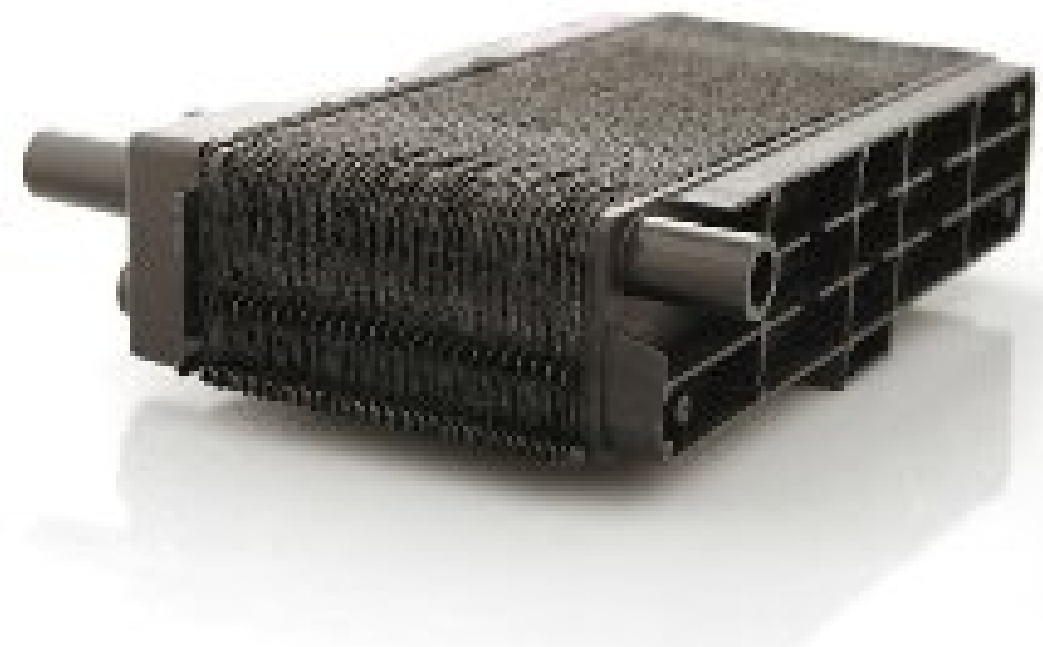

Figure 9-9. Planar Membrane Module

\subsubsection{Fabrication of Full-Scale Radiators}

Based on the sub-scale radiator test results, an 18-fpi louver and a 40-fpi microchannel fin fullscale radiator were built, which showed the best performance in sub-scale radiator testing. The photographs of the radiators are shown in Figure 9-10 and Figure 9-11.

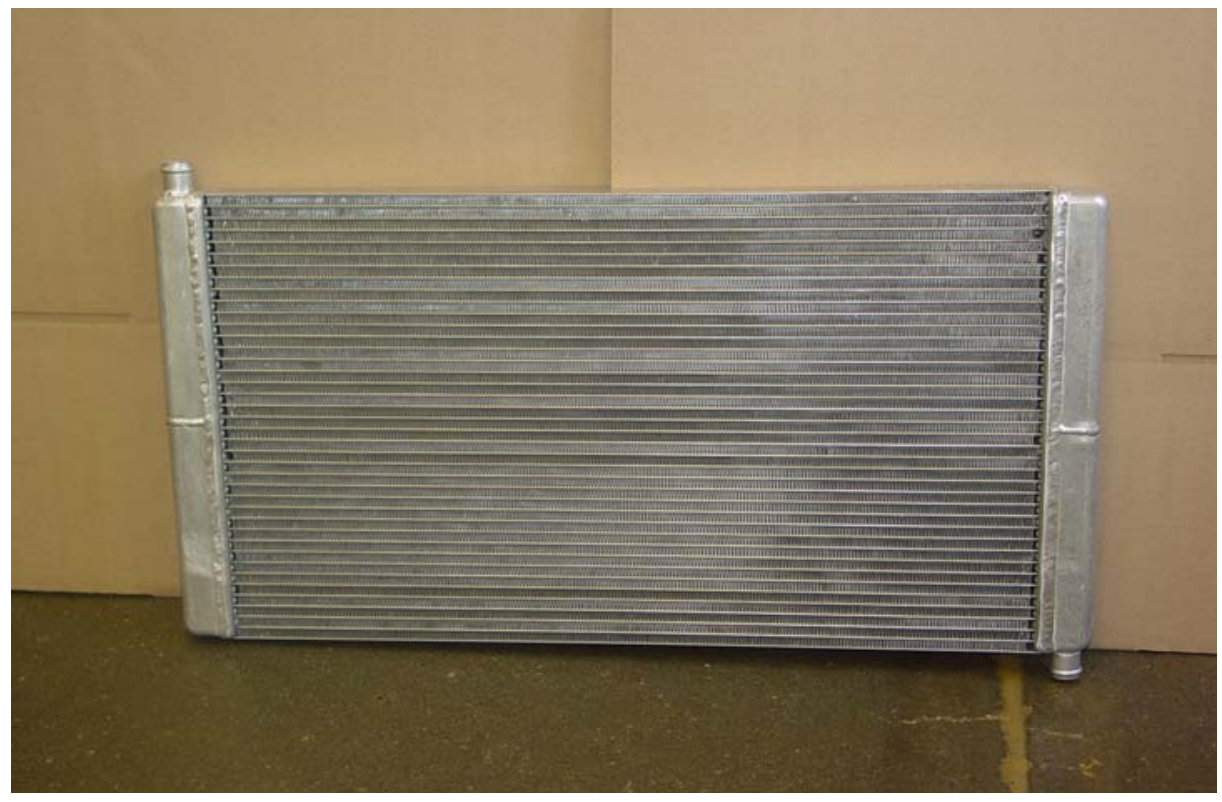

Figure 9-10. Full-Scale Radiator with 18-fpi Louver Fins 


\section{Honeywell}

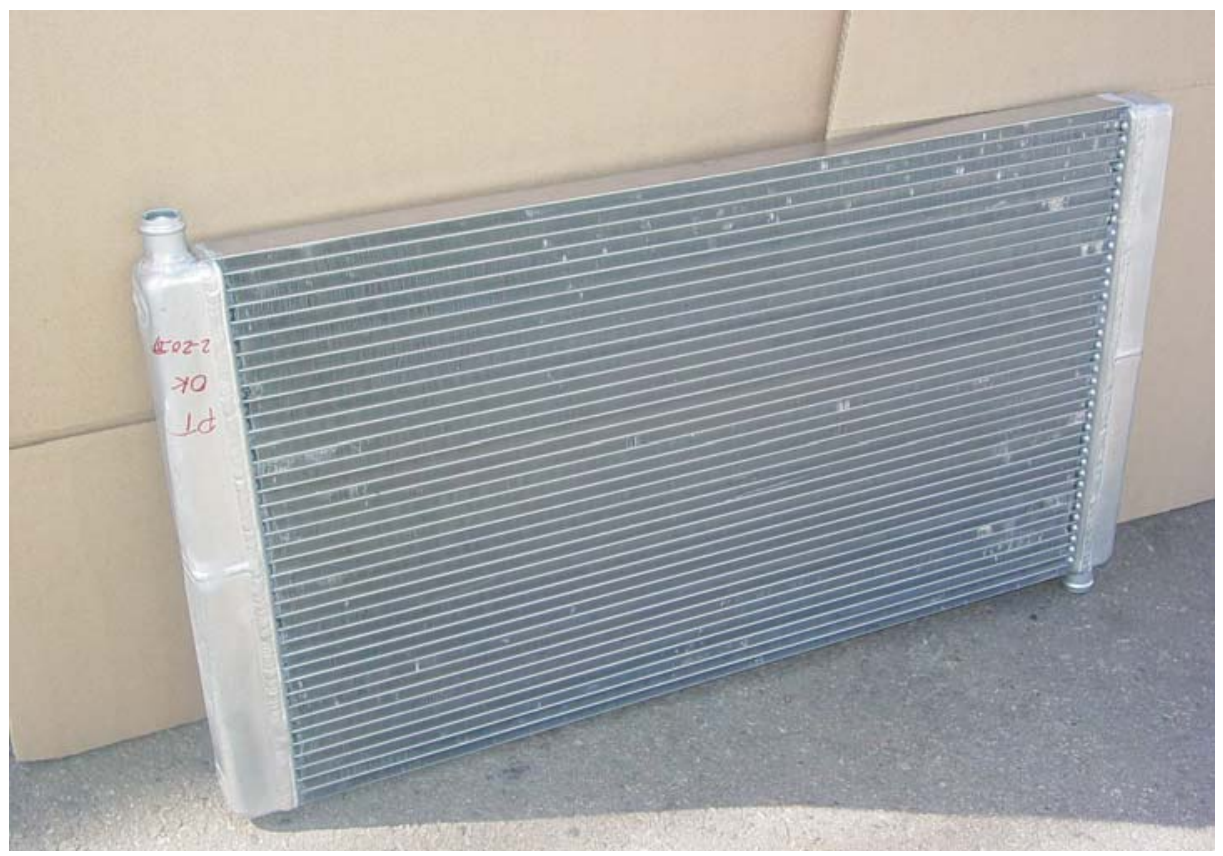

Figure 9-11. Full-Scale Radiator with 40-fpi Microchannel Fins

\subsubsection{Radiator Test Stand}

The test setups for the full-scale radiator and glycol-water circulating system cart are shown in Figure 9-12 and Figure 9-13.

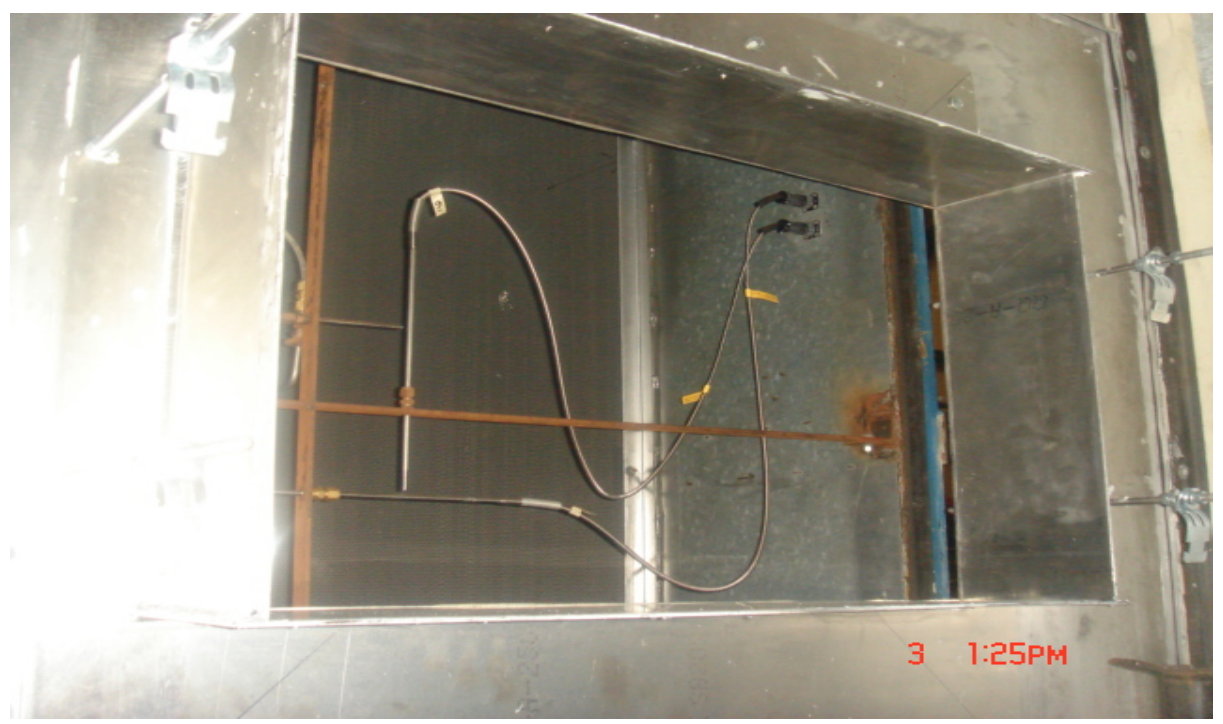

Figure 9-12. Face of Radiator Instrumented for Testing 


\section{Honeywell}

This page has been deleted because it was deemed to contain Honeywell Confidential information. 


\section{Honeywell}

This page has been deleted because it was deemed to contain Honeywell Confidential information. 


\subsection{PROGRAM ACTIVITIES DURING 2010}

\subsection{Water Management}

Check out of the water management test stand has been completed, resulting in acceptable water balances. Also, testing of the full-scale membrane module has been completed.

Two likely causes of the poor water balances ( 70 percent) observed during the initial test stand checkout are identified below:

- Water condensation inside the test article or test stand ducting

- Low steam temperature $\left(\sim 300^{\circ} \mathrm{F}\left[149^{\circ} \mathrm{C}\right]\right)$ at the injection point

Water condensation inside the test stand was mitigated, but not fully eliminated, by adding additional insulation and electric heater tape to the test-stand ducting to maintain duct wall temperatures that are greater than the dew point of the water vapor/air mixture. The low steam temperature at the injection point was eliminated at most test points by removing a restrictive three-way valve in the steam delivery line, in addition to the doubling of the steam line insulation that was previously completed. This enabled a higher steam flow rate and hotter steam duct wall temperatures, which resulted in higher steam flow temperature at the injection point.

After these changes were complete, the team focused on eliminating small leaks from the steam line and improving the humidity measurement accuracy. To find even the smallest steam leaks in the steam line, the team switched from using compressed air to filling the steam line with $\mathrm{R} 134 \mathrm{a}$ refrigerant and sniffing for leaks with a refrigerant leak detector. This method is very sensitive and several very small steam leaks were located and eliminated. After the steam line was leak-tight, the team focused on the humidity measurement devices. Further points were run and repeatable water balances of close to 100 percent were observed for some of the test points. However, small deviations in the inlet conditions would result in large swings in water balance calculations. At this point, the team suspected one or both of the outlet hygrometers was faulty. All three humidity measurement devices were due for calibration and were sent to the manufacturer. Both outlet hygrometers were calibrated without incident according to the manufacturer, but the chilled mirror required a minor repair. At the suggestion of the manufacturer, the settings for the outlet hygrometers were changed so they would output relative humidity (RH percent) instead of dew point when the instruments were reinstalled. When the system was run again, repeatable water balances of close to 100 percent for the test points run were observed. All subsequent testing was completed with the outlet hygrometers in this configuration. The team is not entirely sure why changing the output type made such a large difference. The outlet hygrometers directly measure $\mathrm{RH}$, but to output dew point they have to make a calculation using built-in look-up tables and a temperature value measured by an RTD built into the hygrometer. The team noticed that the process gas temperatures displayed by the hygrometer differed by up to $10^{\circ} \mathrm{F}$ from what was measured by the two outlet RTDs in each circuit. This temperature difference could be a cause of the erratic water balances observed when using the hygrometers in dew point mode. No one change or improvement can be identified as the major cause of the water balance improvement. It appears that all of the changes provided small improvements that when added up made for one large improvement. 
With acceptable water balances achieved, the team proceeded to test the full-scale membrane module. Eighteen points were successfully completed; the inlet conditions are shown in Table 10-1.

\section{Table 10-1. Full-scale Membrane Module Inlet Conditions and Water Balance}

\begin{tabular}{|c|c|c|c|c|c|c|c|c|c|c|}
\hline \multirow[t]{2}{*}{ Case } & $\begin{array}{c}\text { T120 } \\
\text { Primary } \\
\text { Inlet }\end{array}$ & $\begin{array}{c}\text { P120 } \\
\text { Primary } \\
\text { Inlet P }\end{array}$ & $\begin{array}{l}\text { W110 } \\
\text { Primary } \\
\text { Inlet } \\
\text { Flow }\end{array}$ & $\begin{array}{l}\text { Primary } \\
\text { Inlet } \\
\text { Humidity }\end{array}$ & $\begin{array}{c}\text { T210 } \\
\text { Secondary } \\
\text { Inlet }\end{array}$ & $\begin{array}{c}\text { P210 } \\
\text { Secondary } \\
\text { Inlet P }\end{array}$ & $\begin{array}{c}\text { W200 } \\
\text { Secondary } \\
\text { Inlet Flow }\end{array}$ & $\begin{array}{l}\text { DP120- } \\
210 \\
\text { Primary- } \\
\text { Secondary }\end{array}$ & $\begin{array}{c}\text { Secondary } \\
\text { Inlet } \\
\text { Humidity }\end{array}$ & $\begin{array}{c}\text { Water } \\
\text { Balance }\end{array}$ \\
\hline & ${ }^{\circ} \mathrm{F}\left({ }^{\circ} \mathrm{C}\right)$ & $\begin{array}{c}\text { psig } \\
\text { (kPa) }\end{array}$ & $\begin{array}{l}\text { lb/min } \\
\text { (kg.min) }\end{array}$ & RH\% & ${ }^{\circ} \mathrm{F}\left({ }^{\circ} \mathrm{C}\right)$ & $\begin{array}{c}\text { psig } \\
\text { (kPa) }\end{array}$ & $\begin{array}{l}\mathrm{lb} / \mathrm{min} \\
(\mathrm{kg} / \mathrm{min})\end{array}$ & psi (kPa) & RH\% & $\%$ \\
\hline 1 & $\begin{array}{l}157.21 \\
(69.56)\end{array}$ & $\begin{array}{c}17.92 \\
(123.55)\end{array}$ & $\begin{array}{l}10.83 \\
(4.91)\end{array}$ & $0 \%$ & $\begin{array}{l}175.85 \\
(79.92)\end{array}$ & $\begin{array}{c}17.51 \\
(120.73)\end{array}$ & $\begin{array}{l}10.39 \\
(4.71)\end{array}$ & $\begin{array}{c}0.41 \\
(2.83)\end{array}$ & $50 \%$ & 97.1 \\
\hline 1 & $\begin{array}{l}156.16 \\
(68.98)\end{array}$ & $\begin{array}{c}18.51 \\
(127.62)\end{array}$ & $\begin{array}{l}10.83 \\
(4.91)\end{array}$ & $0 \%$ & $\begin{array}{l}177.65 \\
(80.92)\end{array}$ & $\begin{array}{c}17.04 \\
(117.49)\end{array}$ & $\begin{array}{l}10.24 \\
(4.64)\end{array}$ & $\begin{array}{c}1.47 \\
(10.14)\end{array}$ & $66 \%$ & 100.7 \\
\hline 2 & $\begin{array}{l}157.34 \\
(69.63) \\
\end{array}$ & $\begin{array}{c}16.35 \\
(112.73) \\
\end{array}$ & $\begin{array}{c}8.57 \\
(3.89) \\
\end{array}$ & $0 \%$ & $\begin{array}{l}177.28 \\
(80.71) \\
\end{array}$ & $\begin{array}{c}14.12 \\
(97.35) \\
\end{array}$ & $\begin{array}{c}7.82 \\
(3.55) \\
\end{array}$ & $\begin{array}{c}2.27 \\
(15.65) \\
\end{array}$ & $49 \%$ & 96.0 \\
\hline 2 & $\begin{array}{l}157.56 \\
(69.76) \\
\end{array}$ & $\begin{array}{c}14.72 \\
(101.49) \\
\end{array}$ & $\begin{array}{r}8.53 \\
(3.87) \\
\end{array}$ & $0 \%$ & $\begin{array}{c}175.08 \\
(80.6) \\
\end{array}$ & $\begin{array}{c}12.77 \\
(88.05) \\
\end{array}$ & $\begin{array}{c}7.83 \\
(3.55) \\
\end{array}$ & $\begin{array}{c}1.94 \\
(13.38)\end{array}$ & $60 \%$ & 101.1 \\
\hline 2 & $\begin{array}{c}157.46 \\
(69.7) \\
\end{array}$ & $\begin{array}{c}14.58 \\
(100.53) \\
\end{array}$ & $\begin{array}{c}8.50 \\
(3.86) \\
\end{array}$ & $0 \%$ & $\begin{array}{l}173.57 \\
(78.65) \\
\end{array}$ & $\begin{array}{c}12.60 \\
(86.87) \\
\end{array}$ & $\begin{array}{c}7.76 \\
(3.52) \\
\end{array}$ & $\begin{array}{c}1.99 \\
(13.72) \\
\end{array}$ & $76 \%$ & 103.7 \\
\hline 3 & $\begin{array}{c}157.46 \\
(69.7) \\
\end{array}$ & $\begin{array}{c}4.28 \\
(29.51) \\
\end{array}$ & $\begin{array}{c}2.65 \\
(1.20) \\
\end{array}$ & $0 \%$ & $\begin{array}{l}176.28 \\
(80.16) \\
\end{array}$ & $\begin{array}{c}3.70 \\
(25.51) \\
\end{array}$ & $\begin{array}{c}2.38 \\
(1.08) \\
\end{array}$ & $\begin{array}{c}0.66 \\
(4.55) \\
\end{array}$ & $40 \%$ & 93.7 \\
\hline 3 & $\begin{array}{l}157.44 \\
(69.69)\end{array}$ & $\begin{array}{c}4.57 \\
(31.51)\end{array}$ & $\begin{array}{c}2.60 \\
(1.18)\end{array}$ & $0 \%$ & $\begin{array}{l}169.19 \\
(76.22)\end{array}$ & $\begin{array}{c}3.71 \\
(25.58)\end{array}$ & $\begin{array}{c}2.34 \\
(1.06)\end{array}$ & $\begin{array}{c}0.91 \\
(6.83)\end{array}$ & $63 \%$ & 91.9 \\
\hline 3 & $\begin{array}{l}157.53 \\
(69.74)\end{array}$ & $\begin{array}{c}4.73 \\
(32.61)\end{array}$ & $\begin{array}{c}2.57 \\
(1.17)\end{array}$ & $0 \%$ & $\begin{array}{l}170.58 \\
(76.99)\end{array}$ & $\begin{array}{c}3.76 \\
(25.92)\end{array}$ & $\begin{array}{c}2.29 \\
(1.04)\end{array}$ & $\begin{array}{c}1.09 \\
(7.52)\end{array}$ & $77 \%$ & 92.1 \\
\hline 5 & $\begin{array}{l}175.14 \\
(79.52) \\
\end{array}$ & $\begin{array}{c}17.77 \\
(122.52) \\
\end{array}$ & $\begin{array}{l}10.57 \\
(4.79) \\
\end{array}$ & $0 \%$ & $\begin{array}{l}189.89 \\
(87.72) \\
\end{array}$ & $\begin{array}{c}15.24 \\
(105.08)\end{array}$ & $\begin{array}{c}9.96 \\
(4.52) \\
\end{array}$ & $\begin{array}{c}2.56 \\
(17.65) \\
\end{array}$ & $47 \%$ & 111.2 \\
\hline 5 & $\begin{array}{l}176.12 \\
(80.07) \\
\end{array}$ & $\begin{array}{c}16.78 \\
(115.69) \\
\end{array}$ & $\begin{array}{c}9.93 \\
(4.50) \\
\end{array}$ & $0 \%$ & $\begin{array}{l}188.28 \\
(86.82) \\
\end{array}$ & $\begin{array}{c}15.04 \\
(103.70)\end{array}$ & $\begin{array}{c}8.99 \\
(4.08) \\
\end{array}$ & $\begin{array}{c}1.73 \\
(11.93) \\
\end{array}$ & $68 \%$ & 112.4 \\
\hline 6 & $\begin{array}{l}177.25 \\
(80.69) \\
\end{array}$ & $\begin{array}{c}14.74 \\
(101.63) \\
\end{array}$ & $\begin{array}{c}8.33 \\
(3.78) \\
\end{array}$ & $0 \%$ & $\begin{array}{c}195.98 \\
(91.1) \\
\end{array}$ & $\begin{array}{c}12.44 \\
(85.77) \\
\end{array}$ & $\begin{array}{c}7.76 \\
(3.52) \\
\end{array}$ & $\begin{array}{c}2.32 \\
(16.00) \\
\end{array}$ & $41 \%$ & 115.7 \\
\hline 6 & $\begin{array}{l}177.39 \\
(80.77) \\
\end{array}$ & $\begin{array}{c}15.26 \\
(105.21) \\
\end{array}$ & $\begin{array}{c}8.38 \\
(3.80) \\
\end{array}$ & $0 \%$ & $\begin{array}{r}187.35 \\
(86.31) \\
\end{array}$ & $\begin{array}{c}13.06 \\
(90.05) \\
\end{array}$ & $\begin{array}{r}7.78 \\
(3.53) \\
\end{array}$ & $\begin{array}{c}2.21 \\
(15.24) \\
\end{array}$ & $69 \%$ & 114.3 \\
\hline 6 & $\begin{array}{l}177.59 \\
(80.88)\end{array}$ & $\begin{array}{c}14.93 \\
(102.94)\end{array}$ & $\begin{array}{c}8.38 \\
(3.80)\end{array}$ & $0 \%$ & $\begin{array}{l}190.33 \\
(87.96)\end{array}$ & $\begin{array}{c}12.59 \\
(86.80)\end{array}$ & $\begin{array}{c}7.70 \\
(3.49)\end{array}$ & $\begin{array}{c}2.39 \\
(16.48)\end{array}$ & $74 \%$ & 118.2 \\
\hline 7 & $\begin{array}{l}179.72 \\
(82.67) \\
\end{array}$ & $\begin{array}{c}4.59 \\
(31.65) \\
\end{array}$ & $\begin{array}{c}2.75 \\
(1.25) \\
\end{array}$ & $0 \%$ & $\begin{array}{l}194.83 \\
(90.46) \\
\end{array}$ & $\begin{array}{c}4.16 \\
(28.68) \\
\end{array}$ & $\begin{array}{c}2.36 \\
(1.07) \\
\end{array}$ & $\begin{array}{c}0.49 \\
(3.38) \\
\end{array}$ & $35 \%$ & 119.9 \\
\hline 7 & $\begin{array}{l}178.15 \\
(81.19) \\
\end{array}$ & $\begin{array}{c}4.56 \\
(31.44) \\
\end{array}$ & $\begin{array}{c}2.56 \\
(1.16) \\
\end{array}$ & $0 \%$ & $\begin{array}{l}186.55 \\
(85.86) \\
\end{array}$ & $\begin{array}{c}4.01 \\
(27.65) \\
\end{array}$ & $\begin{array}{c}2.33 \\
(1.06) \\
\end{array}$ & $\begin{array}{c}0.61 \\
(4.21)\end{array}$ & $79 \%$ & 114.1 \\
\hline 8 & $\begin{array}{l}177.36 \\
(80.76) \\
\end{array}$ & $\begin{array}{c}1.23 \\
(8.48) \\
\end{array}$ & $\begin{array}{c}0.92 \\
(0.42) \\
\end{array}$ & $0 \%$ & $\begin{array}{r}197.77 \\
(92.09) \\
\end{array}$ & $\begin{array}{c}1.19 \\
(8.20)\end{array}$ & $\begin{array}{c}0.97 \\
(0.44) \\
\end{array}$ & $\begin{array}{c}0.11 \\
(0.76) \\
\end{array}$ & $30 \%$ & 101.9 \\
\hline 8 & $\begin{array}{l}176.86 \\
(80.48) \\
\end{array}$ & $\begin{array}{c}1.34 \\
(9.24) \\
\end{array}$ & $\begin{array}{c}0.93 \\
(0.42) \\
\end{array}$ & $0 \%$ & $\begin{array}{r}199.03 \\
(92.79) \\
\end{array}$ & $\begin{array}{c}1.20 \\
(8.27) \\
\end{array}$ & $\begin{array}{c}0.94 \\
(0.43) \\
\end{array}$ & $\begin{array}{c}0.20 \\
(1.38) \\
\end{array}$ & $35 \%$ & 109.8 \\
\hline 8 & $\begin{array}{l}178.08 \\
(81.16) \\
\end{array}$ & $\begin{array}{c}1.55 \\
(10.69) \\
\end{array}$ & $\begin{array}{c}0.95 \\
(0.43) \\
\end{array}$ & $0 \%$ & $\begin{array}{r}192.23 \\
(89.02) \\
\end{array}$ & $\begin{array}{c}1.10 \\
(7.58) \\
\end{array}$ & $\begin{array}{c}0.96 \\
(0.44) \\
\end{array}$ & $\begin{array}{c}0.51 \\
(3.52) \\
\end{array}$ & $33 \%$ & 94.7 \\
\hline
\end{tabular}

Data reduction and analysis for the full-scale membrane test data are currently underway. Water condensation between the steam injection point and the secondary inlet of the membrane module seems to be causing the high water balances observed for cases 6 and 7 . This condensed water will not be measured by the outlet hygrometer resulting in the high water balance. A plot of the temperatures observed for the secondary inlet RTDs show significant scatter compared to the other temperature measurements. This is thought to be caused by 


\section{Honeywell}

water droplets exiting the heat exchanger used to cool the secondary inlet air after steam injection. The water droplets hit the RTDs, causing large temperature fluctuations to be observed. This phenomenon is shown in Figure 10-1. From the other observed test data, the capability of the test stand with respect to water balance (total water in / total water out) seems to be on the order of \pm 10 percent.

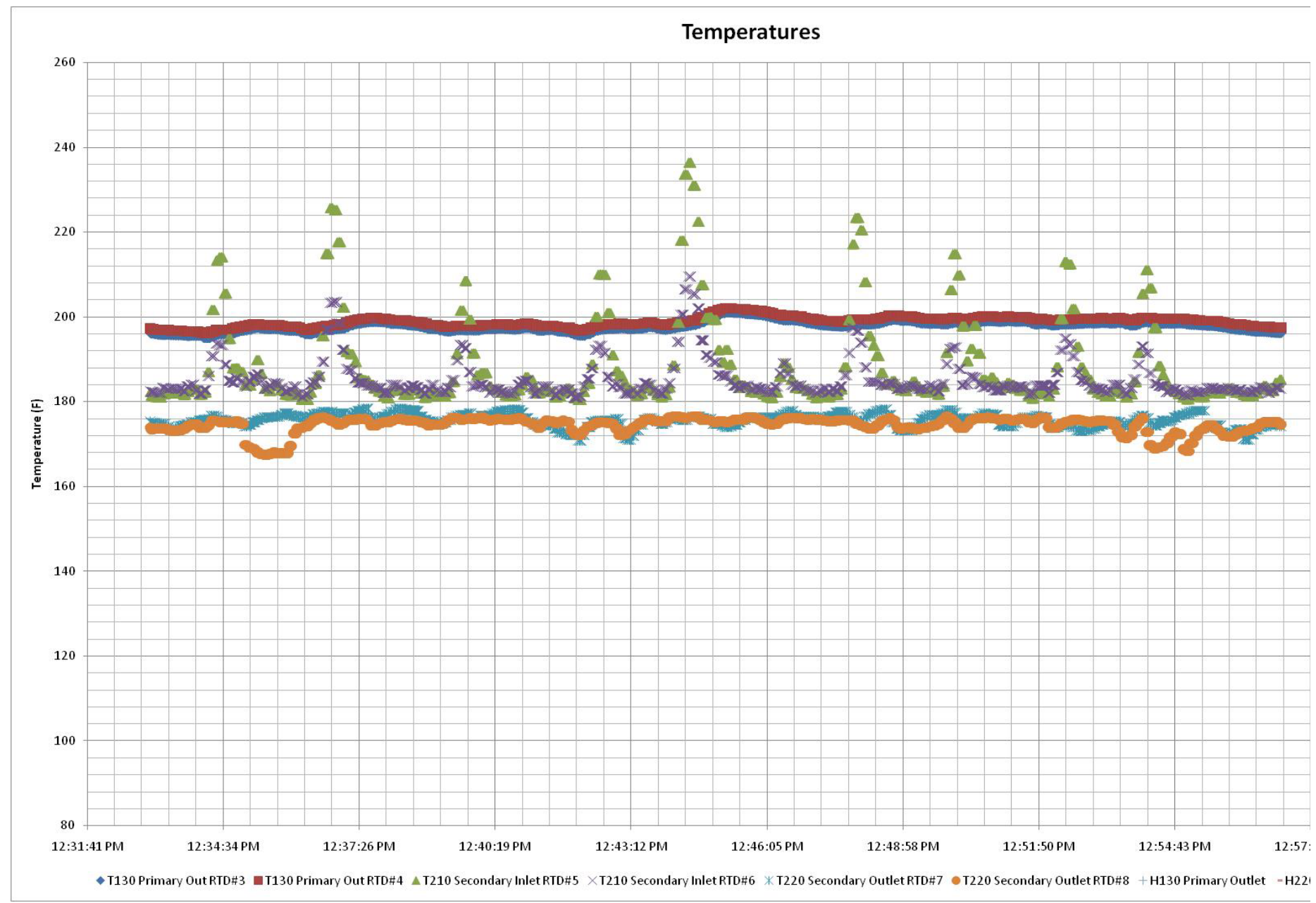

Figure 10-1. Example of Secondary Inlet Temperature Stratification for Case 6 and Case 7

Going forward, the team is reducing and analyzing the full-scale membrane test data and will be setting up the test stand to test the half-scale membrane module and the enthalpy wheel.

\subsection{Full-scale Membrane Module Testing}

In the last quarter of 2009, the test data presented for the full-scale membrane module showed acceptable water balances. Eighteen test points were successfully completed, and the data were presented in the last quarterly report. The water balance is reasonably good.

The humidity of the inlet stream (secondary flow) and outlet stream (primary in) is plotted against average flow rates to humidifier inlet and outlet flow streams in Figure 10-2. Due to instrumentation and test stand limitations, the humidity of the humidifier inlet stream was limited 
to about 80 percent. The data scatter cannot be explained; each test point was taken when the system reached the steady-state condition. This test data was also shared with Argonne National Laboratory, so that they can input the data into their fuel cell system model.

The secondary inlet stream humidity data is adjusted higher (close to 100 percent), which resulted in higher humidity for the primary flow. Even after the adjustment, the primary flow is still lower than the 60 percent required for the PEM fuel cell, particularly at higher flow rates.

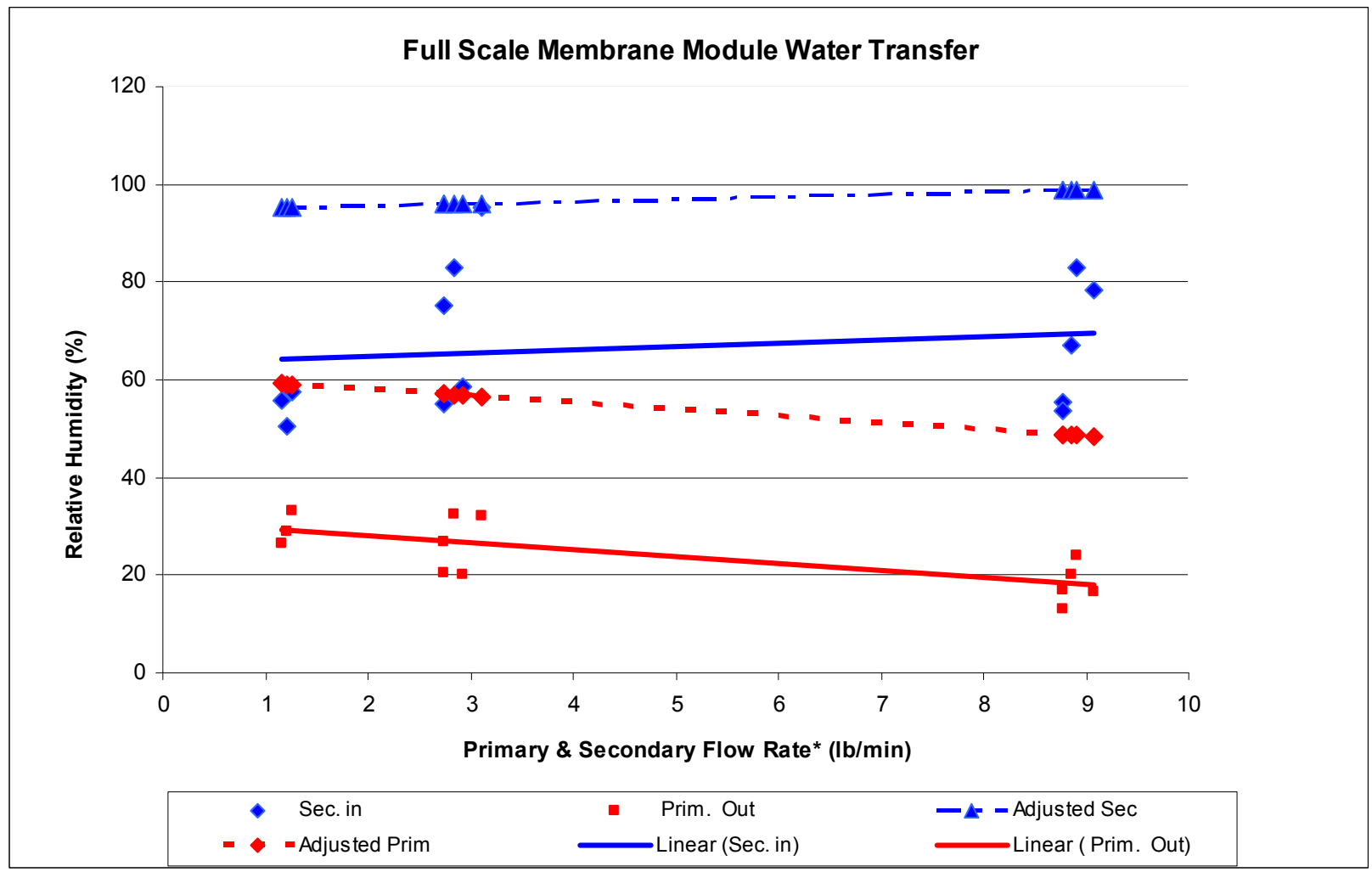

Figure 10-2. Humidity of Inlet and Outlet Streams Compared with Average Flow Rates to Humidifier Inlet and Outlet Flow Streams

${ }^{*}$ Average flow rate of primary and secondary streams is used. The flow variations were less than 11 percent.

The test stand was reconfigured for sub-scale membrane module testing. The initial tests were conducted with run conditions similar to those for the full-scale module and the results were comparable. The full-scale module had 7000 tubes and the sub-scale had 2500 tubes. The diameters and lengths were the same; hence, the sub-scale flows had a ratio of 2500:7000, or 1:2.8. Both primary and secondary airflows were scaled by this factor from the full-scale values. To keep the $\mathrm{RH}$ the same as full-scale, the water flow was adjusted accordingly.

Going forward, additional test points will be run on the sub-scale unit prior to installing the enthalpy wheel. The results of the sub-scale membrane test data are presented next. 


\section{Honeywell}

\subsection{Sub-scale Membrane Module Testing}

The test stand was reconfigured for sub-scale membrane module testing (see Figure 10-3). Initial tests were conducted using run conditions similar to those for the full-scale module; the water transfer rate for the sub-scale unit was 10 to 15 percent lower than for the full-scale unit. The full-scale module has 7000 tubes and the sub-scale has 2500 tubes. The diameters and lengths are the same; hence, the sub-scale flows had a ratio of 2500:7000, or 1:2.8. Both primary and secondary airflows were scaled by this factor from the full-scale values. To keep the RH the same as full-scale, the water flow was adjusted accordingly.

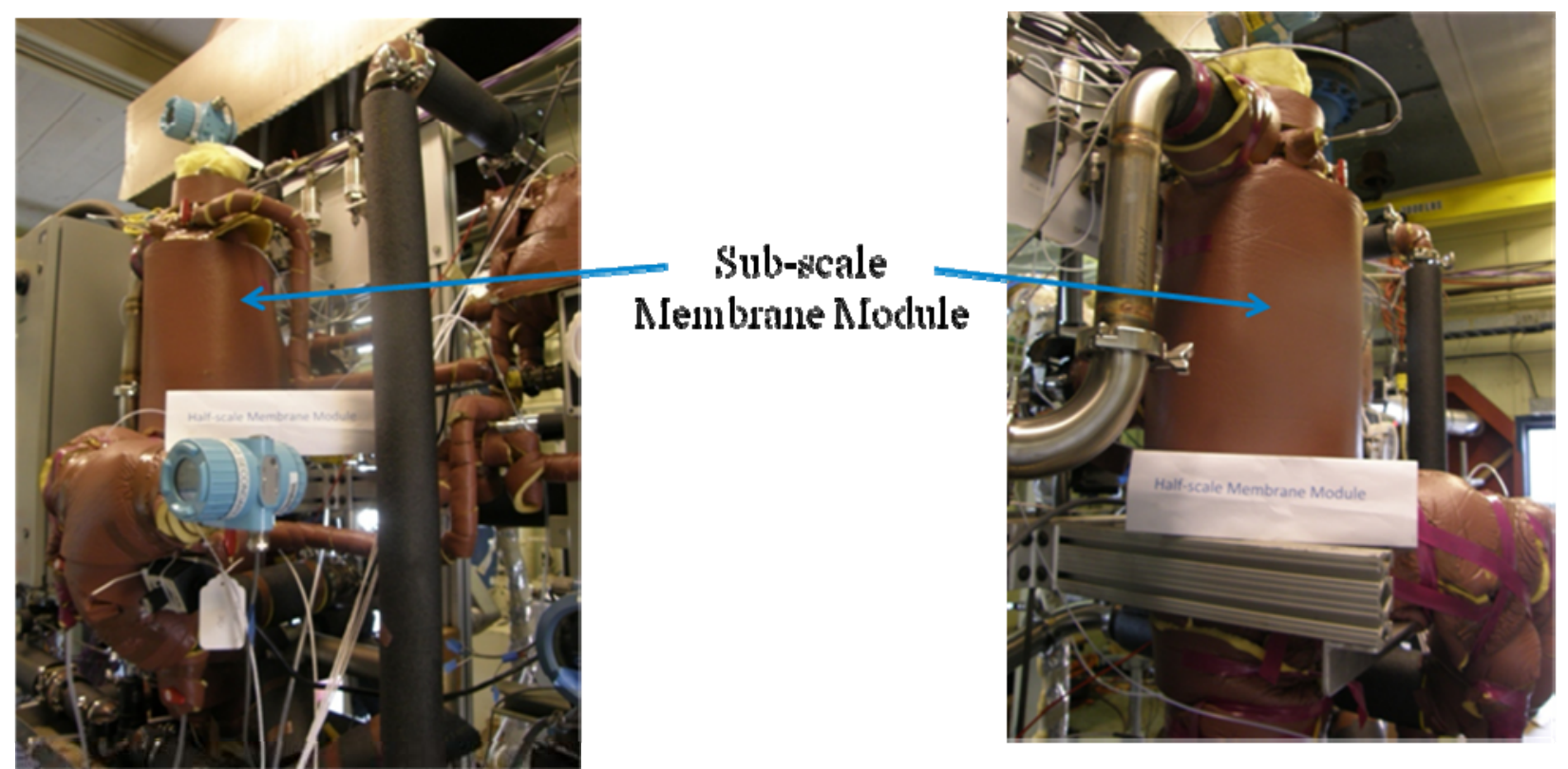

Figure 10-3. Sub-scale Membrane Module Under Test

The sub-scale test matrix was derived using the above rationale from the full-scale version. Given the lower flows, heat loss to the surroundings is difficult to avoid (particularly for the water stream). Some of the set points in the full-set matrix were judged to be not attainable. Hence, a subset was selected and the following cases were selected:

Cases 1B, 1C, 2A, 2B, 2C, 5A, 5B, 5C, 6A, 6B, 6C

These cases were run twice: first, the initial run (February 9 and March 31), then the repeatability assessment (April 8 ). The results were consistent and within expectations.

The fuel cell inlet air stream and exit air stream referred to in this report correspond to humidifier exit and inlet streams, respectively.

The fuel cell inlet air flow humidity was plotted against the fuel cell inlet air flow in Figure 10-4, which represents the water transfer rate. The same test conditions were repeated and the data is plotted in Figure 10-5. Due to test stand and measuring instrumentation limitations, the maximum humidity that could be accurately measured was 80 percent. Assuming the constant transfer rate, at 100 percent humidity, the maximum water transfer would be 37 to 42 percent short of the required 60-percent requirement. 


\section{Honeywell}

The water balance data for the sub-scale humidifier at various water injection rates are presented in Figure 10-6 and the repeat test data is shown in Figure 10-7. The data scatter at the higher flow rate was an indication of measurement difficulties and inaccuracies at highhumidity conditions.

The water transfer efficiency of the sub-scale humidifier was lower than full-scale by more than 10 to 15 percentage points from when the unit was tested earlier.

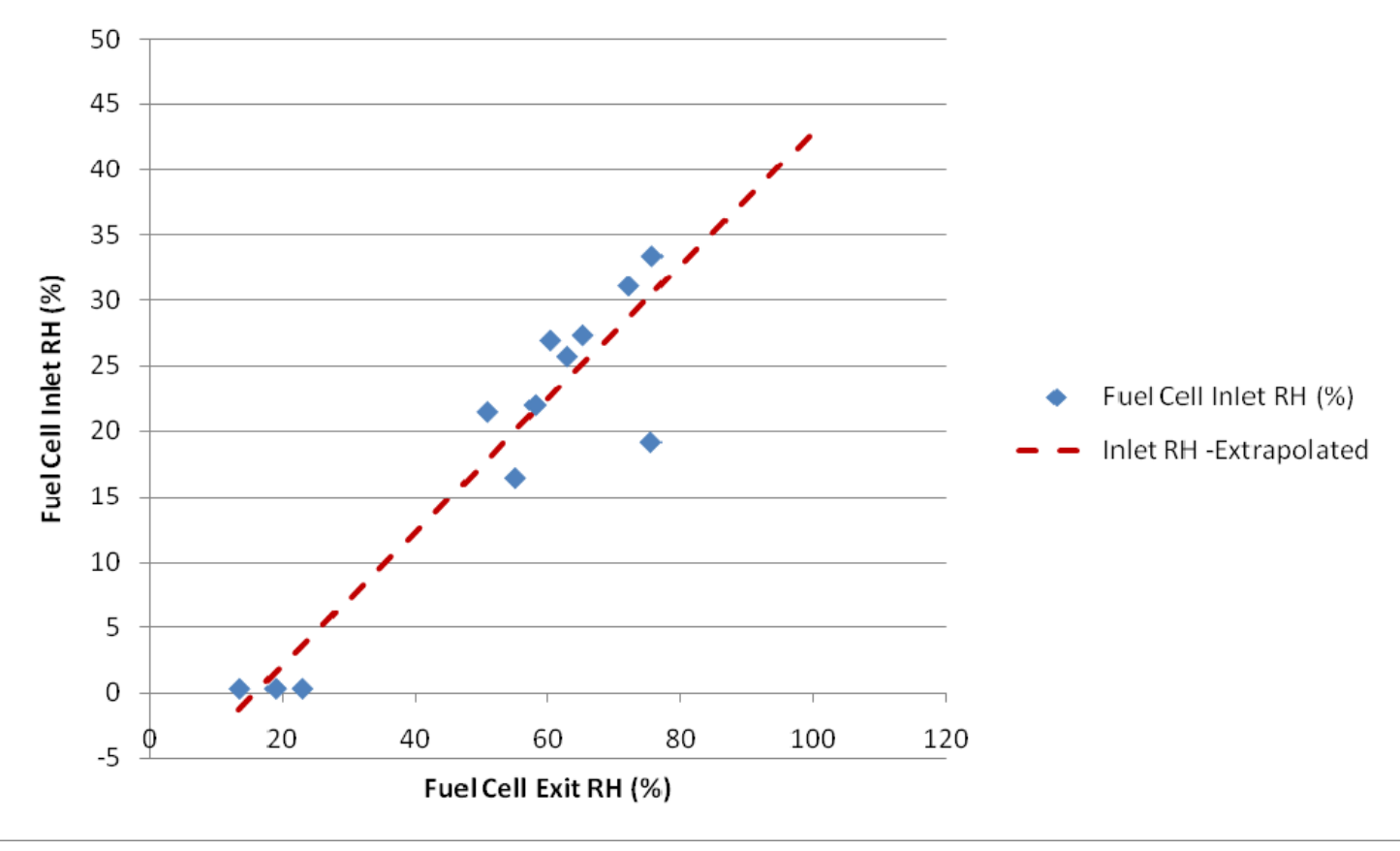

Figure 10-4. Fuel Cell Inlet RH vs. Fuel Cell Exit RH 
Honeywell

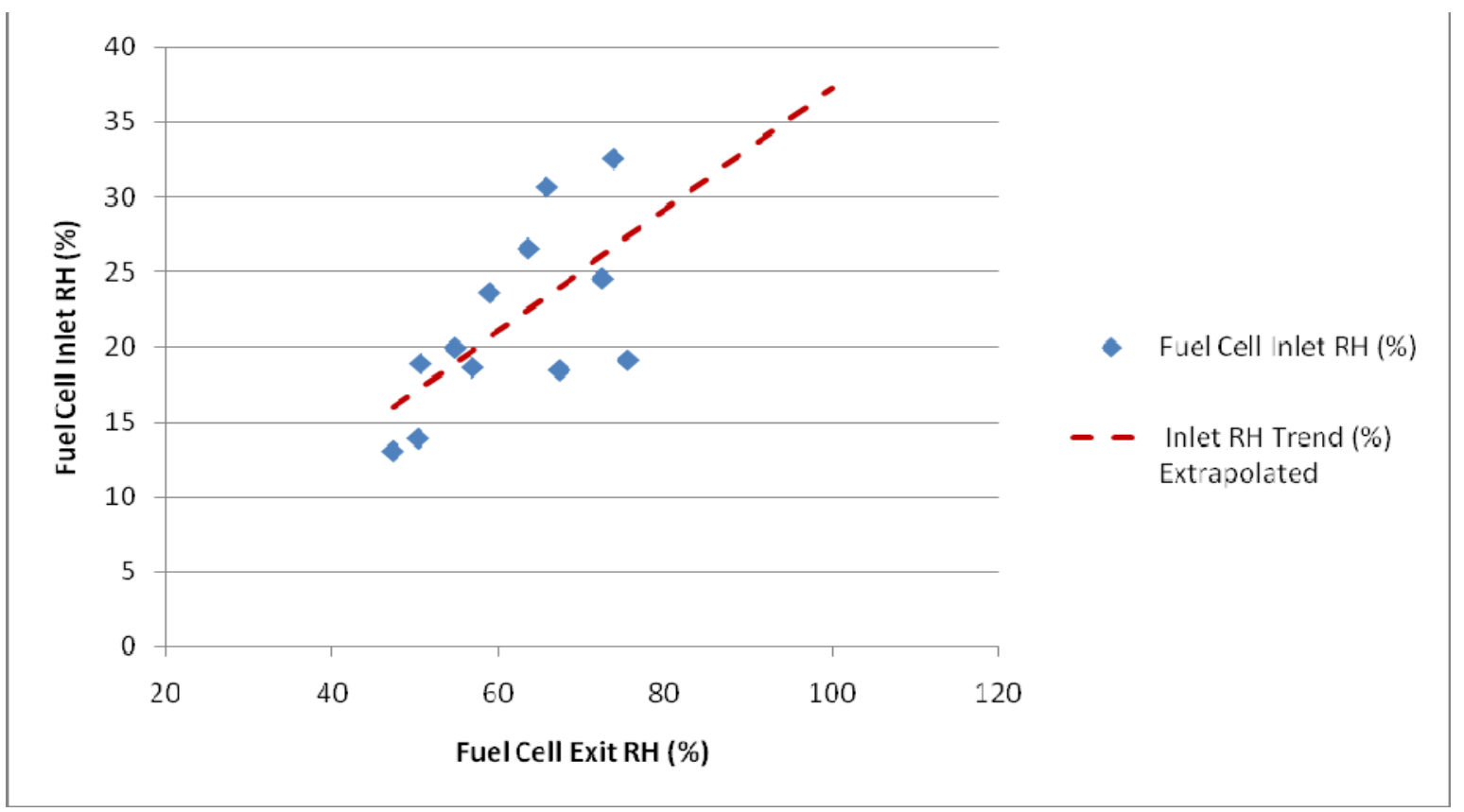

Figure 10-5. Fuel Cell Inlet RH vs. Fuel Cell Exit RH and Trend Extrapolated to 100 Percent Exit RH

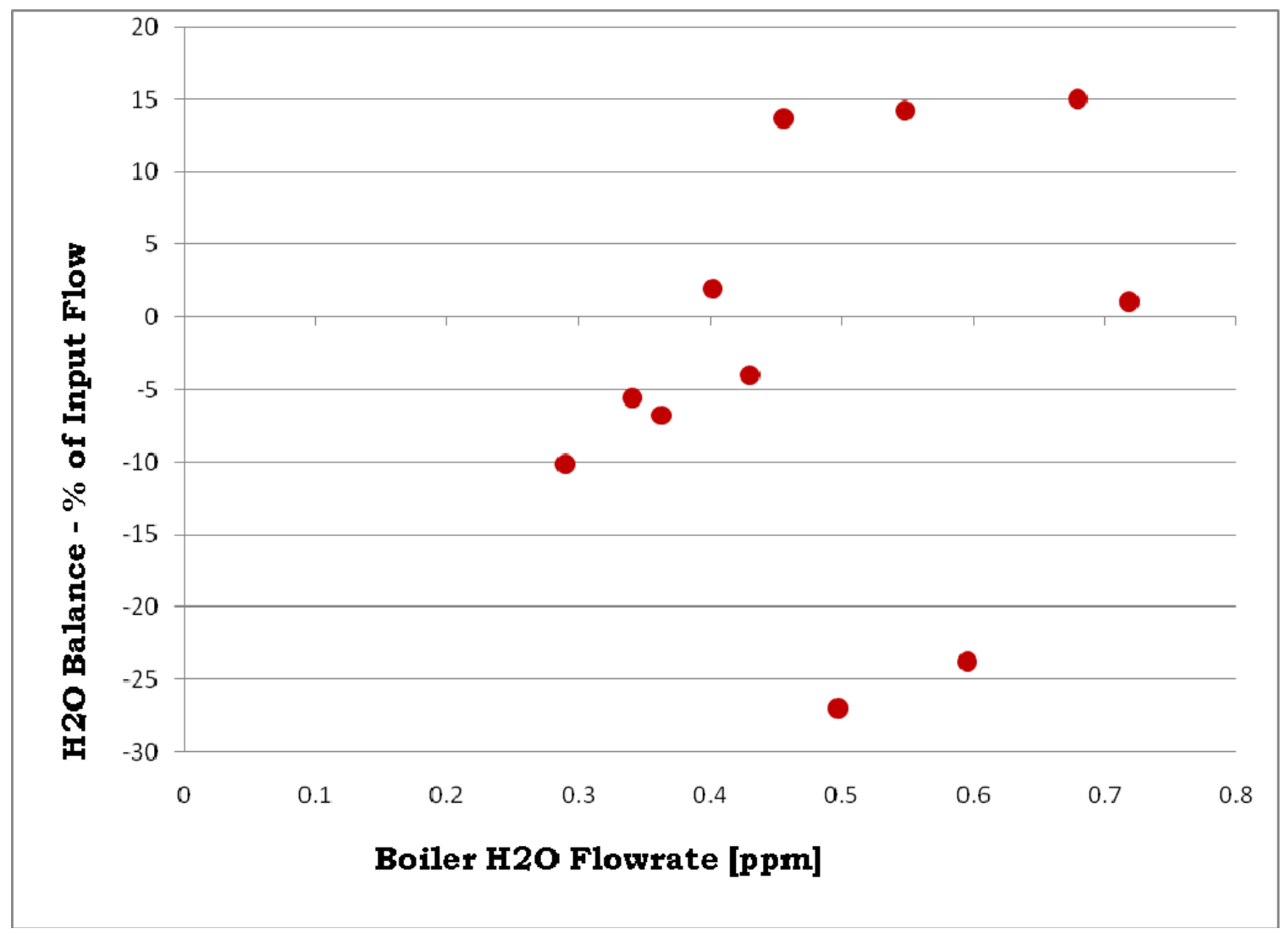

Figure 10-6. Water Mass Balance Percent as a Function of Boiler Water Feed Rate 


\section{Honeywell}

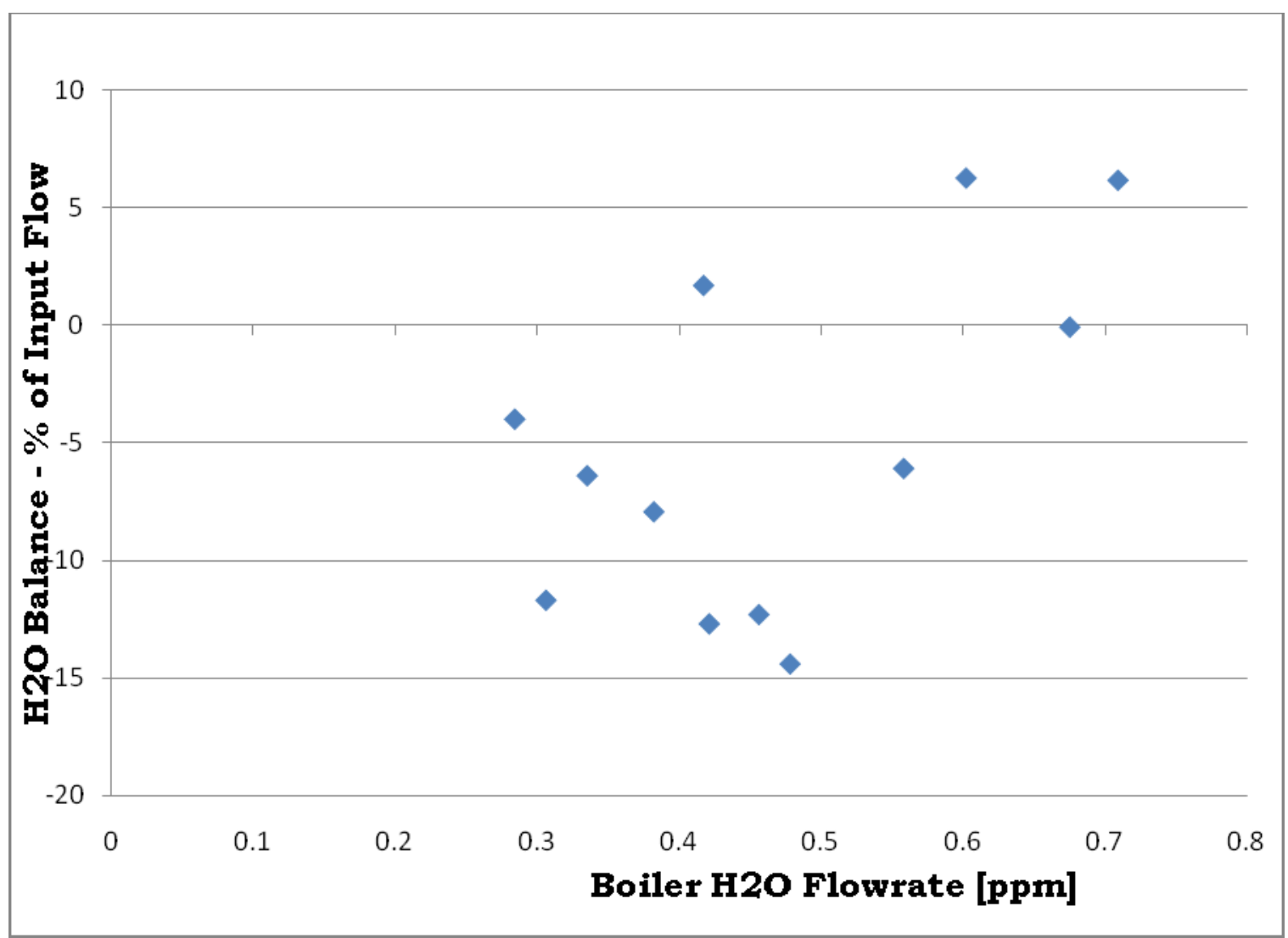

Figure 10-7. Water Mass Balance Percent as a Function of Boiler Water Feed Rate, Repeat Test Data

\subsection{Planar Membrane Module Testing}

The planar membrane module, which is the last humidification system for the PEM fuel cell application, was tested. The planar humidifier had an advantage in manufacturing cost and installation, as compared with the circular Perma Pure membrane module. This unit was supplied by dPoint Technology Inc., Vancouver, Canada (Figure 10-8).

The specification of the unit is provided below.

- Max operating temp: $176^{\circ} \mathrm{F}\left(80^{\circ} \mathrm{C}\right)$ and operating pressure of $35 \mathrm{psi}(241 \mathrm{kPa})$

- Size $(\mathrm{LxWxH}): 115$ inches $(292 \mathrm{~cm}) \times 9.3$ inches $(236.22 \mathrm{~mm}) \times 5.4$ inches $(137.16 \mathrm{~mm})$

- Model Px4: 10.55 in (268 mm) pleated humidifier

- Maximum air flow rate: $12 \mathrm{lb} / \mathrm{min}(5.44 \mathrm{~kg} / \mathrm{min})$

- Membrane by Gore

The water transfer efficiency for the planar humidifier varied from 20 to 35 percent, as shown in Figure 10-9. The water transfer rate was lower at higher water content in the inlet air flow. The difference in performance cannot be explained. The water balance data for the various test cases is plotted in Figure 10-10. The water balance improved with higher water content in the 


\section{Honeywell}

inlet air flow stream due to the improved measurement at high water content. The test data was presented in Table 10-2.

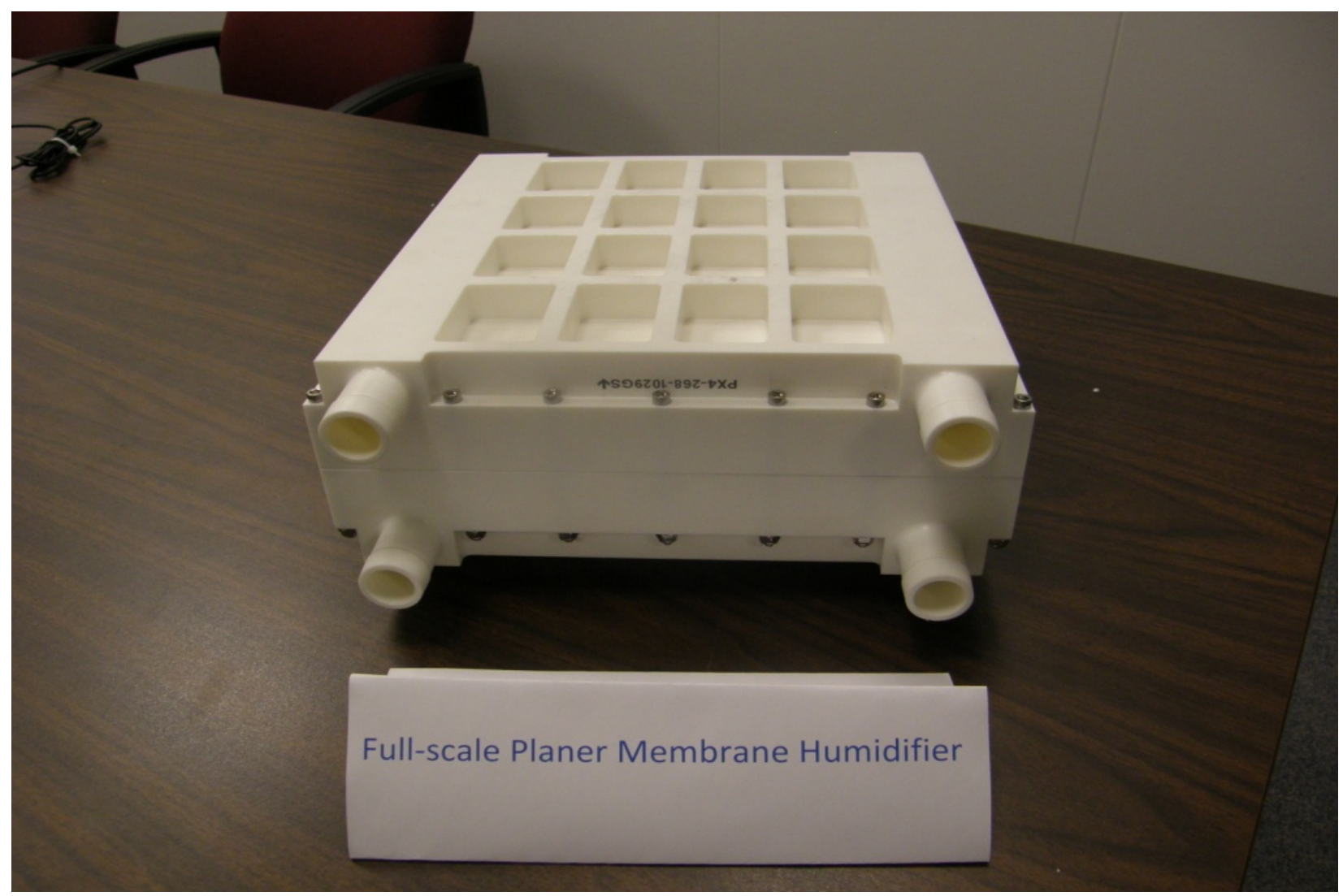

Figure 10-8. Full-scale Planar Membrane Module 
Honeywell

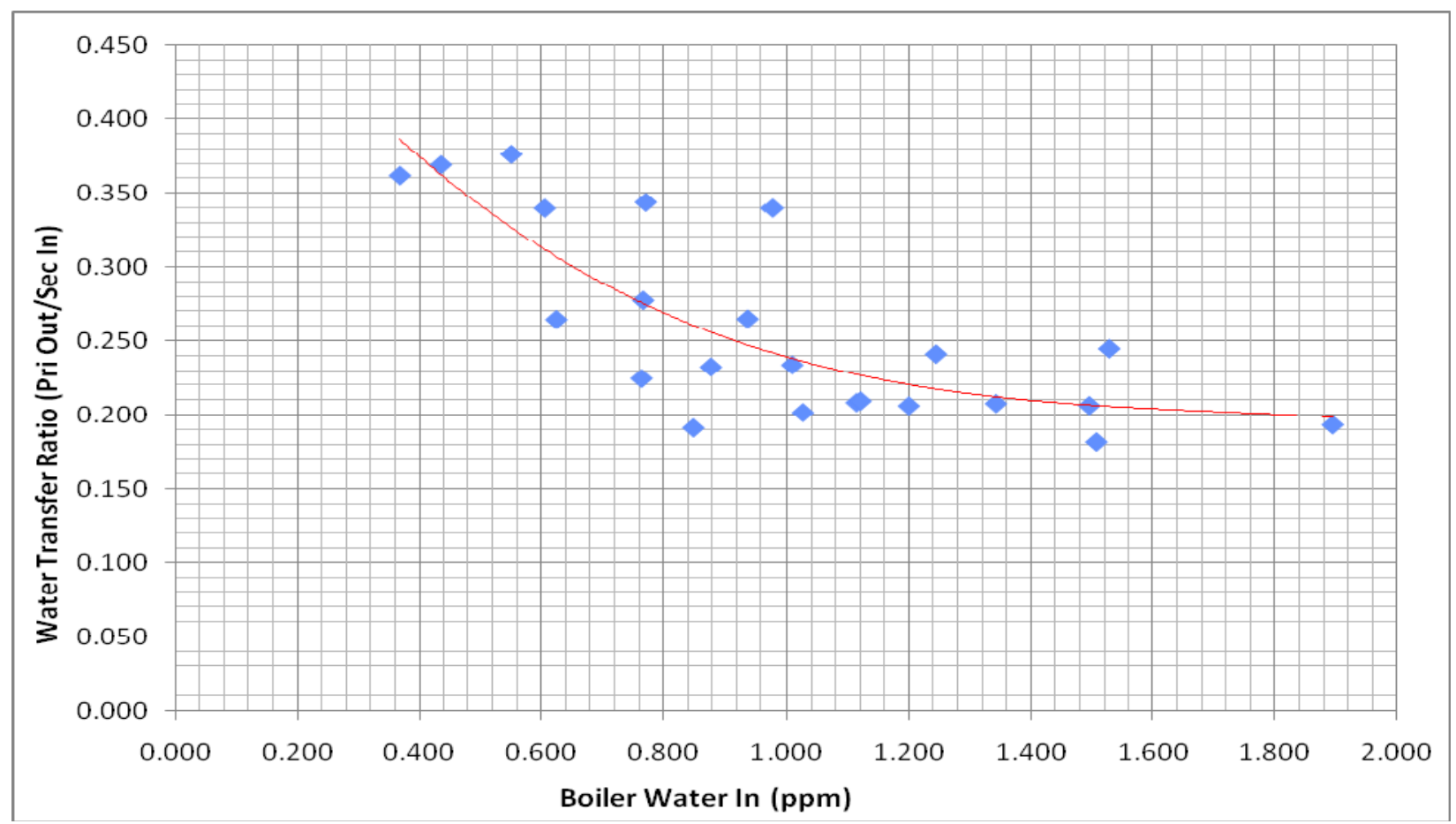

Figure 10-9. Water Transfer Ratio as a Function of Total Water Flow

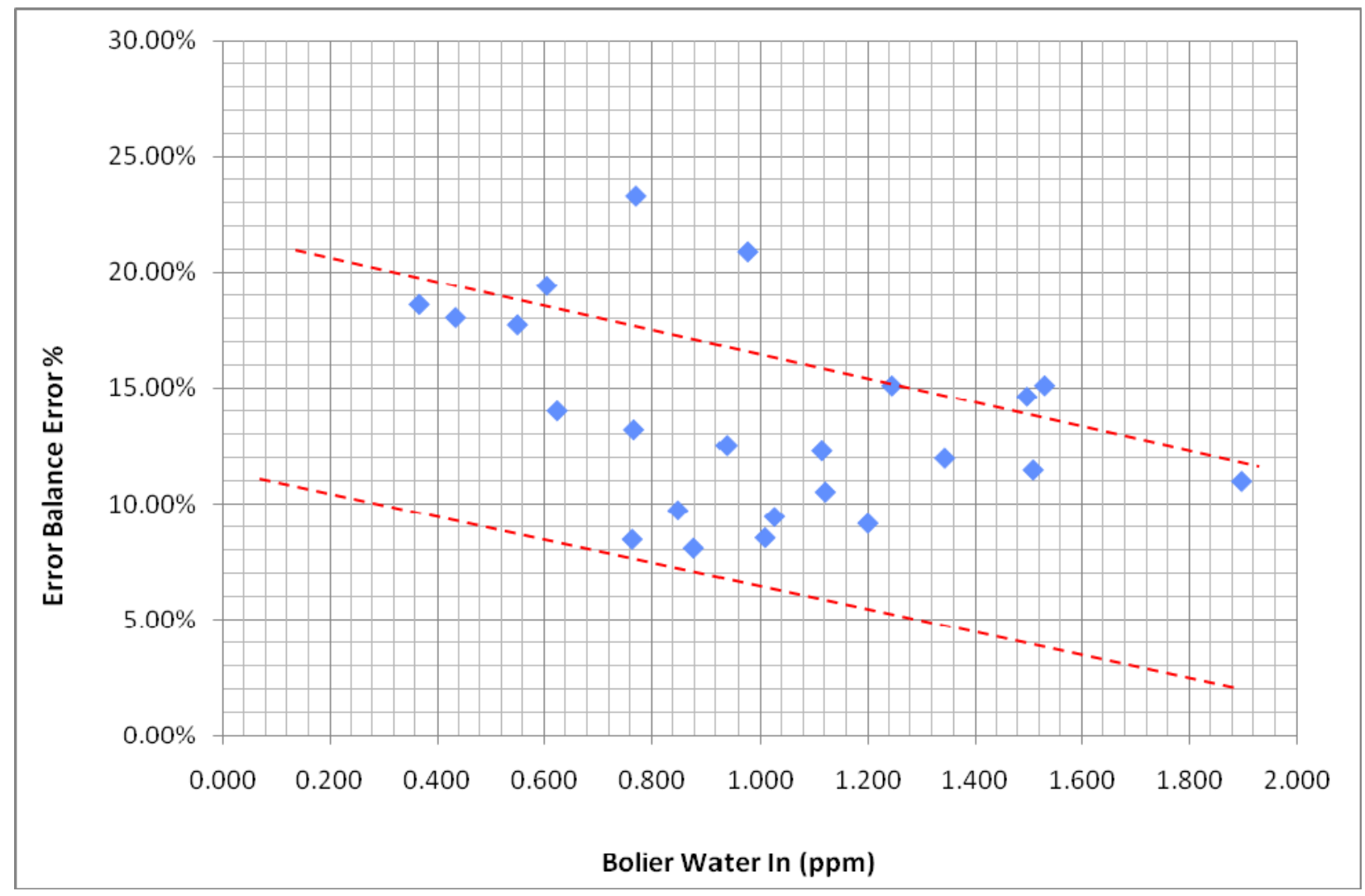

Figure 10-10. Water Balance Error as a Function of Total Water Flow

11-77418, Rev. 1

$10-10$ 
Honeywell

Table 10-2. Planar Membrane Module Test Matrix

\begin{tabular}{|c|c|c|c|c|c|c|c|c|c|c|c|c|}
\hline \multicolumn{13}{|c|}{2010 Planar Membrane Module Test Points } \\
\hline \multirow[b]{2}{*}{ Case } & \multicolumn{3}{|c|}{ Primary In (1) } & \multirow[b]{2}{*}{$\begin{array}{c}\Delta P \\
\text { (Dry- } \\
\text { Wet), } \\
\text { psi } \\
\text { (kPa) }\end{array}$} & \multicolumn{8}{|c|}{ 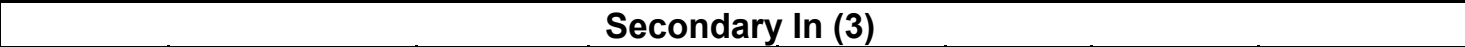 } \\
\hline & $\begin{array}{l}\text { Air Flow } \\
\text { Rate, } \\
\text { Ib/min } \\
\text { (kg/min) }\end{array}$ & $\begin{array}{c}\text { Air Flow } \\
\text { Temperature, } \\
{ }^{\circ} \mathrm{F}\left({ }^{\circ} \mathrm{C}\right)\end{array}$ & \begin{tabular}{|c|} 
Air \\
Pressure, \\
psig \\
$(\mathrm{kPa})$ \\
\end{tabular} & & $\begin{array}{l}\text { Air Flow } \\
\text { Rate, } \\
\text { Ib/min } \\
\text { (kg/min) }\end{array}$ & $\begin{array}{c}\text { Dry Bulb } \\
\text { Temperature, } \\
{ }^{\circ} \mathrm{F}\left({ }^{\circ} \mathrm{C}\right)\end{array}$ & \begin{tabular}{|c|} 
Air \\
Pressure, \\
psig \\
(kPa) \\
\end{tabular} & $\begin{array}{c}\text { Relative } \\
\text { Humidity, } \\
\%\end{array}$ & $\begin{array}{c}\text { Absolute } \\
\text { Humidity, } \\
\text { gr/lb }\end{array}$ & \begin{tabular}{|} 
Water \\
Flow, \\
Ib/min \\
(kg/min)
\end{tabular} & $\begin{array}{l}\text { Dew } \\
\text { Point, } \\
{ }^{\circ} \mathrm{F}\left({ }^{\circ} \mathrm{C}\right)\end{array}$ & $\begin{array}{l}\text { Dry Bulb } \\
\text { Dew Point, } \\
{ }^{\circ} \text { F }\left({ }^{\circ} \mathrm{C}\right)\end{array}$ \\
\hline $1 \mathrm{~A} / 1$ & \multirow{3}{*}{$\begin{array}{r}12.05 \\
(5.47)\end{array}$} & \multirow{3}{*}{$157(69)$} & \multirow{3}{*}{$\begin{array}{c}22.05 \\
(152.03)\end{array}$} & \multirow{3}{*}{$\begin{array}{c}3.00 \\
(20.68)\end{array}$} & \multirow{3}{*}{$\begin{array}{r}10.86 \\
(4.93)\end{array}$} & $176(80)$ & $\begin{array}{c}19.05 \\
(131.35) \\
\end{array}$ & 55 & 549 & \begin{tabular}{|c|}
0.852 \\
$(0.386)$ \\
\end{tabular} & $151(66)$ & $25.38(-3.68)$ \\
\hline $1 \mathrm{~B} / 1$ & & & & & & $176(80)$ & $\begin{array}{c}19.05 \\
(131.35)\end{array}$ & 65 & 664 & $\begin{array}{c}1.031 \\
(0.468)\end{array}$ & $157(69)$ & $18.53(-7.48)$ \\
\hline $1 \mathrm{C} / 1$ & & & & & & $176(80)$ & $\begin{array}{c}19.05 \\
(131.35) \\
\end{array}$ & 75 & 785 & $\begin{array}{c}1.218 \\
(0.552) \\
\end{array}$ & $163(73)$ & $\begin{array}{c}12.51 \\
(-10.83) \\
\end{array}$ \\
\hline $2 \mathrm{~A} / 1$ & \multirow{3}{*}{$\begin{array}{c}8.61 \\
(3.91)\end{array}$} & \multirow{3}{*}{$157(69)$} & \multirow{3}{*}{$\begin{array}{c}14.70 \\
(101.35)\end{array}$} & \multirow{3}{*}{$\begin{array}{c}2.20 \\
(15.17)\end{array}$} & \multirow{3}{*}{$\begin{array}{c}7.81 \\
(3.54)\end{array}$} & $176(80)$ & $\begin{array}{c}12.50 \\
(86.18)\end{array}$ & 55 & 703 & $\begin{array}{c}0.785 \\
(0.356)\end{array}$ & $151(66)$ & $25.38(-3.68)$ \\
\hline $2 \mathrm{~B} / 1$ & & & & & & $176(80)$ & $\begin{array}{c}12.50 \\
(86.18)\end{array}$ & 65 & 856 & $\begin{array}{c}0.955 \\
(0.433)\end{array}$ & $157(69)$ & $18.53(-7.48)$ \\
\hline $2 \mathrm{C} / 1$ & & & & & & $176(80)$ & $\begin{array}{c}12.50 \\
(86.18)\end{array}$ & 75 & 1018 & $\begin{array}{c}1.137 \\
(0.516)\end{array}$ & $163(73)$ & $\begin{array}{c}12.51 \\
(-10.83)\end{array}$ \\
\hline $2.5 \mathrm{~A} / 1$ & \multirow{3}{*}{$\begin{array}{c}5.00 \\
(2.27)\end{array}$} & \multirow{3}{*}{$157(69)$} & \multirow{3}{*}{$\begin{array}{c}9.20 \\
(63.43)\end{array}$} & \multirow{3}{*}{$\begin{array}{c}1.20 \\
(8.27)\end{array}$} & \multirow{3}{*}{$\begin{array}{c}5.00 \\
(2.27)\end{array}$} & $176(80)$ & $\begin{array}{c}8.00 \\
(55.16)\end{array}$ & 55 & 870 & $\begin{array}{c}0.621 \\
(0.282)\end{array}$ & $151(66)$ & $25.38(-3.68)$ \\
\hline $2.5 \mathrm{~B} / 1$ & & & & & & $176(80)$ & $\begin{array}{c}8.00 \\
(55.16)\end{array}$ & 65 & 1067 & $\begin{array}{c}0.762 \\
(0.346)\end{array}$ & 157 (69) & $18.53(-7.48)$ \\
\hline $2.5 \mathrm{C} / 1$ & & & & & & $176(80)$ & $\begin{array}{c}8.00 \\
(55.16)\end{array}$ & 75 & 1279 & $\begin{array}{c}0.914 \\
(0.415)\end{array}$ & $163(73)$ & $\begin{array}{c}12.51 \\
(-10.83)\end{array}$ \\
\hline $3 \mathrm{~A} / 1$ & \multirow{3}{*}{$\begin{array}{c}2.52 \\
(1.14)\end{array}$} & \multirow{3}{*}{157 (69) } & \multirow{3}{*}{$\begin{array}{c}4.41 \\
(30.41)\end{array}$} & \multirow{3}{*}{$\begin{array}{c}0.60 \\
(4.14)\end{array}$} & \multirow{3}{*}{$\begin{array}{c}2.25 \\
(1.02)\end{array}$} & $176(80)$ & $\begin{array}{c}3.81 \\
(26.27)\end{array}$ & 55 & 1117 & $\begin{array}{c}0.359 \\
(0.163)\end{array}$ & $151(66)$ & $25.38(-3.68)$ \\
\hline $3 \mathrm{~B} / 1$ & & & & & & $176(80)$ & $\begin{array}{c}3.81 \\
(26.27)\end{array}$ & 65 & 1385 & $\begin{array}{c}0.446 \\
(0.202)\end{array}$ & $157(69)$ & $18.53(-7.48)$ \\
\hline $3 \mathrm{C} / 1$ & & & & & & $176(80)$ & $\begin{array}{c}3.81 \\
(26.27)\end{array}$ & 75 & 1681 & $\begin{array}{c}0.541 \\
(0.245)\end{array}$ & 163 (163) & $\begin{array}{c}12.51 \\
(-10.83)\end{array}$ \\
\hline $5 \mathrm{~A} / 1$ & \multirow{3}{*}{$\begin{array}{c}12.05 \\
(5.47)\end{array}$} & \multirow{3}{*}{$177(81)$} & \multirow{3}{*}{$\begin{array}{c}22.05 \\
(152.03)\end{array}$} & \multirow{3}{*}{$\begin{array}{c}3.00 \\
(20.68)\end{array}$} & \multirow{3}{*}{$\begin{array}{r}10.86 \\
(4.93)\end{array}$} & $194(90)$ & $\begin{array}{c}19.05 \\
(131.35)\end{array}$ & 55 & 865 & $\begin{array}{c}1.342 \\
(0.609) \\
\end{array}$ & $167(75)$ & $27.01(-2.77)$ \\
\hline $5 B / 1$ & & & & & & $194(90)$ & $\begin{array}{c}19.05 \\
(131.35)\end{array}$ & 65 & 1061 & $\begin{array}{c}1.646 \\
(0.747)\end{array}$ & $174(79)$ & $19.73(-6.82)$ \\
\hline $5 \mathrm{C} / 1$ & & & & & & $194(90)$ & $\begin{array}{c}19.05 \\
(131.35)\end{array}$ & 75 & 1271 & $\begin{array}{c}1.973 \\
(0.895)\end{array}$ & $181(83)$ & $\begin{array}{c}13.33 \\
(-10.37)\end{array}$ \\
\hline
\end{tabular}

11-77418, Rev. 1

$10-11$ 


\section{Honeywell}

Table 10-2. Planar Membrane Module Test Matrix

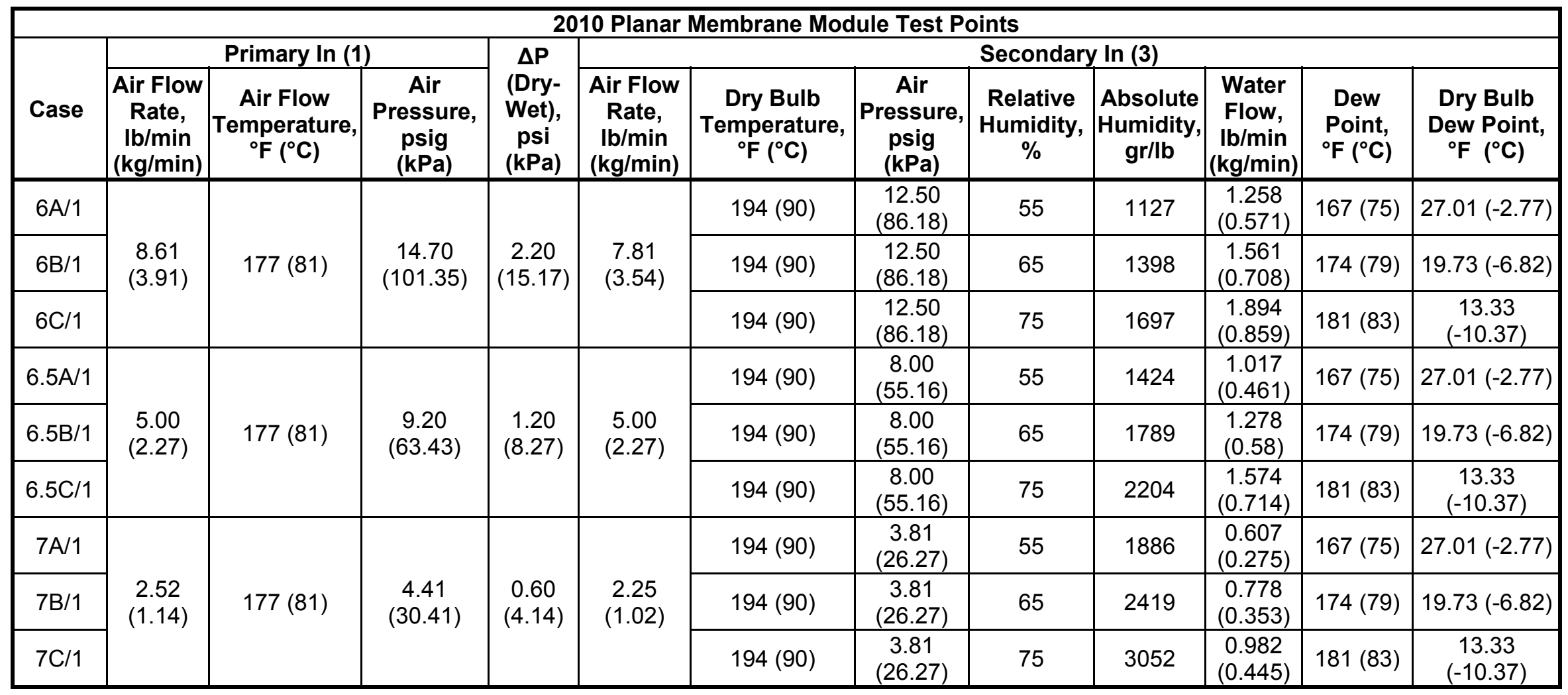




\section{Honeywell}

\subsection{Thermal Management}

The full-scale radiator air-side effectiveness and pressure drop test data for both 18-fpi and 40fpi radiators was presented in the July 2009 quarterly report. The test data was in good agreement with the performance model predictions.

Now that the full-scale radiator performance model is validated, it will be a useful tool for predicting the performance of radiators at any operating conditions. This performance data will be incorporated in the fuel cell system model by Argonne National Laboratory. 


\section{Honeywell}

\subsection{PROGRAM ACTIVITIES DURING 2011}

The performance testing of all four humidification systems was completed in 2010 and the results were provided in Section 10.0. A summary of results is provided below.

- The planar membrane module average water balance during the testing was 15 percent and water was better at higher humidity. The water transfer rate across the membrane was between 20 to 37 percent. The transfer efficiency at low humidity was over 35 percent; however, it decreased with increase in humidity.

- The enthalpy wheel water balance was under 10 percent for most of the test points, except at high flow conditions. The water transfer rate from the high humidity stream to the low humidity air stream was much better than that for membrane systems. At high wheel rotational speed, the water transfer was 65 to 85 percent, which met the 60 percent humidity requirements for the PEM fuel cell inlet air stream.

- The full-scale membrane module performance was close to that for the sub-scale unit. The water balance at high humidity was between 10 to 15 percent. However, at low air humidity the balance was very poor. The test points were repeated without any success and the reason for the poor balance could not be ascertained. The average water transfer rate was between 20 to 30 percent. The water transfer rate decreased with increases in humidity.

- The sub-scale membrane module average water balance was 13 percent with much lower variation during the entire water humidity test range. The water transfer rate was 20 to 37 percent.

The performance data for the three membrane-based humidification systems showed the decrease in water transfer rate with increase in air stream humidity. The enthalpy wheel performance actually increased with increases in the humidity level.

After completion of the tests for all four humidifiers, the next planned activity was to test the most promising unit at sub-ambient conditions. Argonne National Laboratory, the fuel cell automobile system integrator, informed Honeywell that the humidifier will not be used in a subambient environment. With agreement from DOE, it was decided not to pursue the sub-ambient testing and to redirect the remaining funding for reliability testing of the selected humidification system for the PEM fuel cell automobile.

A copy of the proposed plan presentation to DOE is provided in Appendix B. The following two options were identified by mutual discussion between Honeywell and ANL.

1. Select and test two humidification devices for reliability by cycling the humidity in the inlet air stream.

2. Acquire another humidity sensing device that may be more accurate (to \pm 2 percent).

These options were presented to the DOE program office (see presentation in Appendix B) and Option 1 was selected for the remaining effort for FY2011 funding.

The test stand schematics for the reliability testing were finalized and provided in Figure 11-1. The modification was being performed. The enthalpy wheel and planar membrane module were selected for reliability testing. The operability and integrity of both units were verified by leak 


\section{Honeywell}

testing each unit at the beginning of the test and at regular intervals. The testing was started in March 2011.

A total of 5,000 cycles were conducted to validate the reliability of the humidification system. Each cycle consisted of flowing the high humid air ( $\sim 50$ percent humidity) for 2 minutes and then switching to dry air for 2 minutes.

\section{$11.1 \quad$ Procedure}

The reliability test procedure was as follows:

1. Perform a leak check for all the flow circuits of the system.

2. Test the functionality of the bypass valves and set the 2-minute cycle time.

3. Set the desired air flow rate in each circuit with back pressure valves in both flow conditions (e.g., through the test unit and in the bypass mode).

4. Prior to starting the test, make sure that the high humidity air flow circuit is steady state with constant humidity level.

5. Record humidity data during each day for 10 to 20 cycles to assure system operability.

6. The testing will be conducted for two shifts each day (about 200 cycles per day). The test run will be 13.5 hours with additional time in the morning for setup.

7. Monitor the pressure drop across the two circuits to verify membrane or seal integrity and water transfer rate across the two flow streams. 


\section{Honeywell}

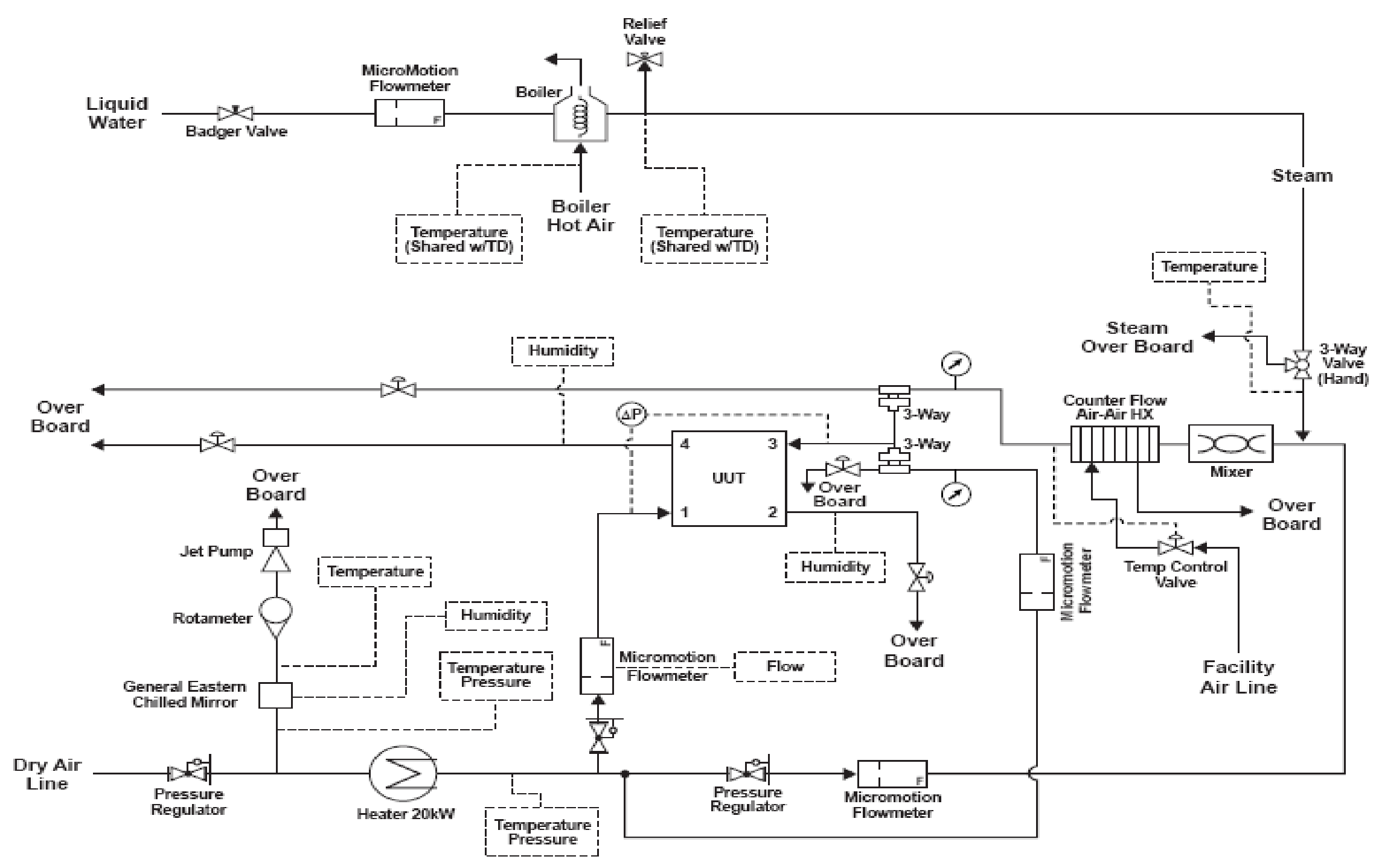

Figure 11-1. Test Stand Schematics for Reliability Test

11-77418, Rev. 1

11-3 
The test setup for the reliability testing of the planar membrane module was completed and the testing was started. A total of 3300 cycles were completed by the end of May 2011. The initial 150 cycles were run for 4 minutes each, where humid and dry air flow maintained for 2 minutes each. Due to time constraints and high air usage, it was decided to decrease the total cycle time to 2 minutes. The inlet humidity during high cycle and low cycle was maintained at about 50 and 0 percent, respectively. The test data for a typical 2-minute cycle is shown in Figure 11-2 and Figure 11-3. The water transfer rate during each cycle was very consistent throughout the cycling test.

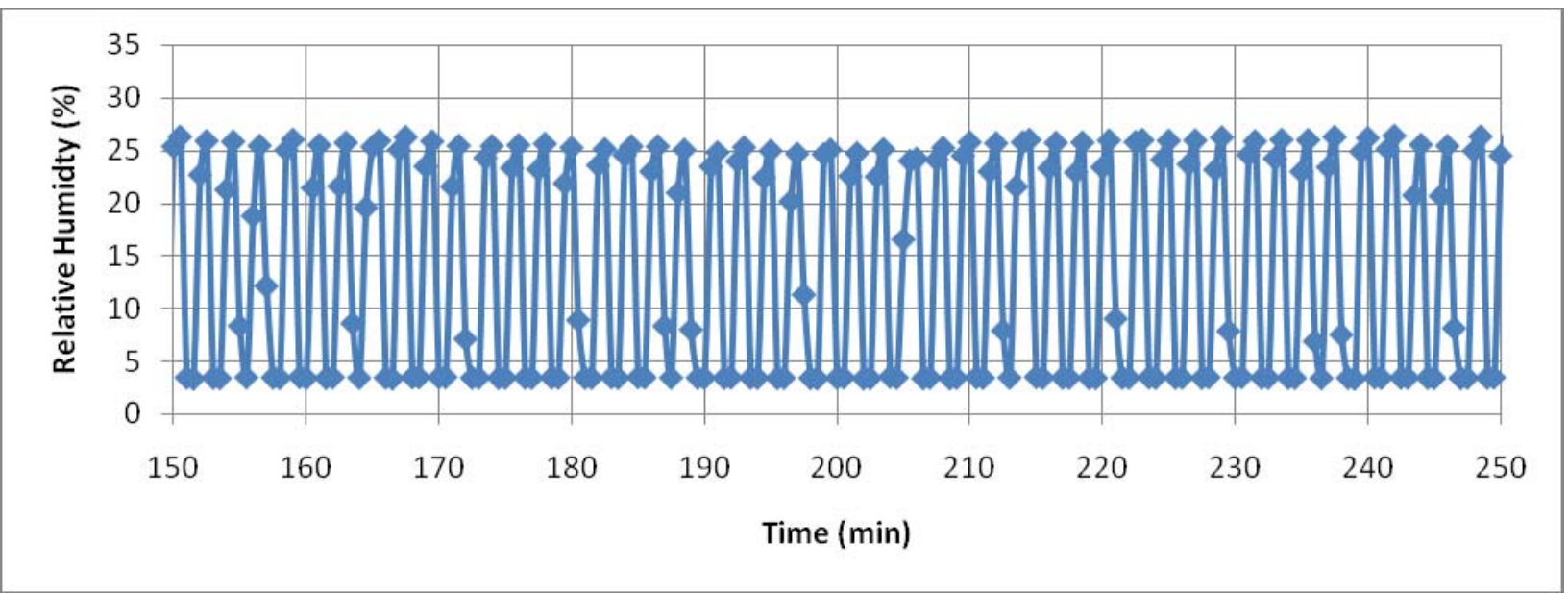

Figure 11-2. Typical 2-Minute Humidity Cycles

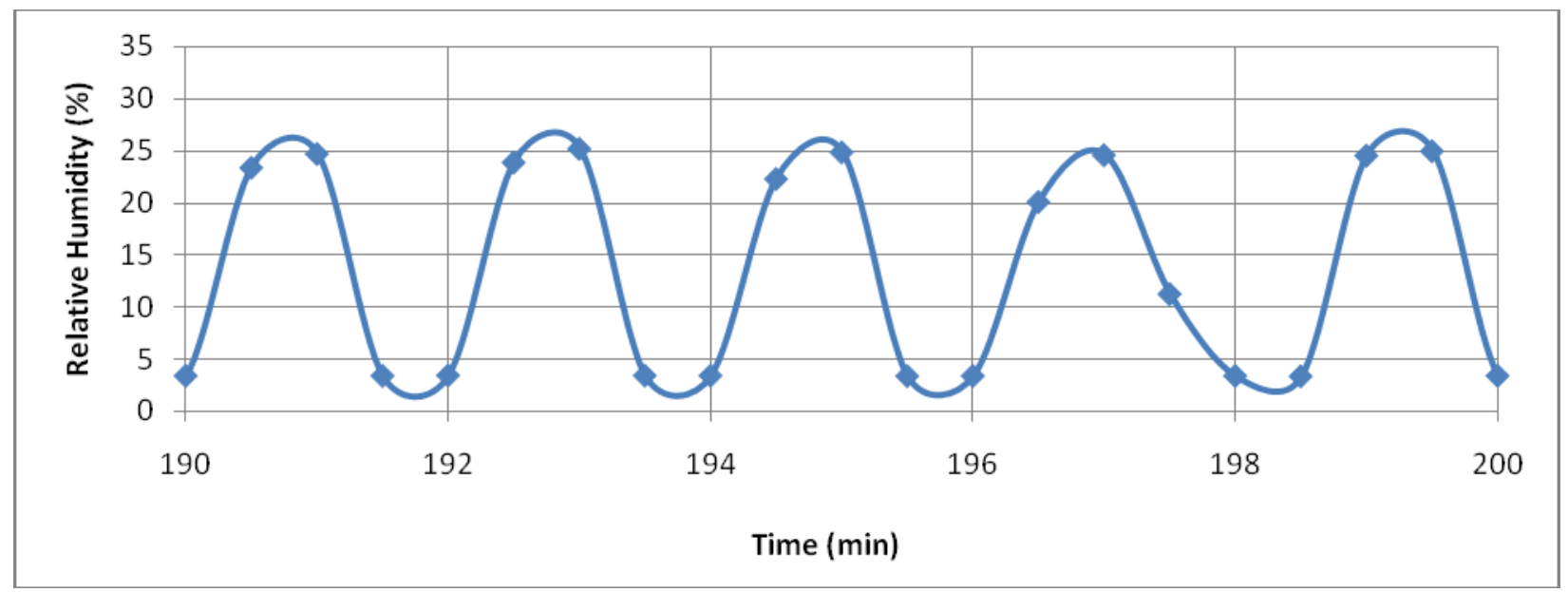

Figure 11-3. Typical 2-Minute Humidity Cycles

The leakage across the membrane module was measured periodically. The leak check was made at four pressures of 1, 2, 3, and $4 \mathrm{inHg}$. The leakage increase was quite linear (as shown in Figure 11-4) with the number of cycles. Even though the leakage increased, it was still within the acceptable limit as confirmed by the supplier (dPoint Technology Inc.). The reason for the steady increase in leakage could not be explained, particularly since unit transfer efficiency was not affected. 


\section{Honeywell}

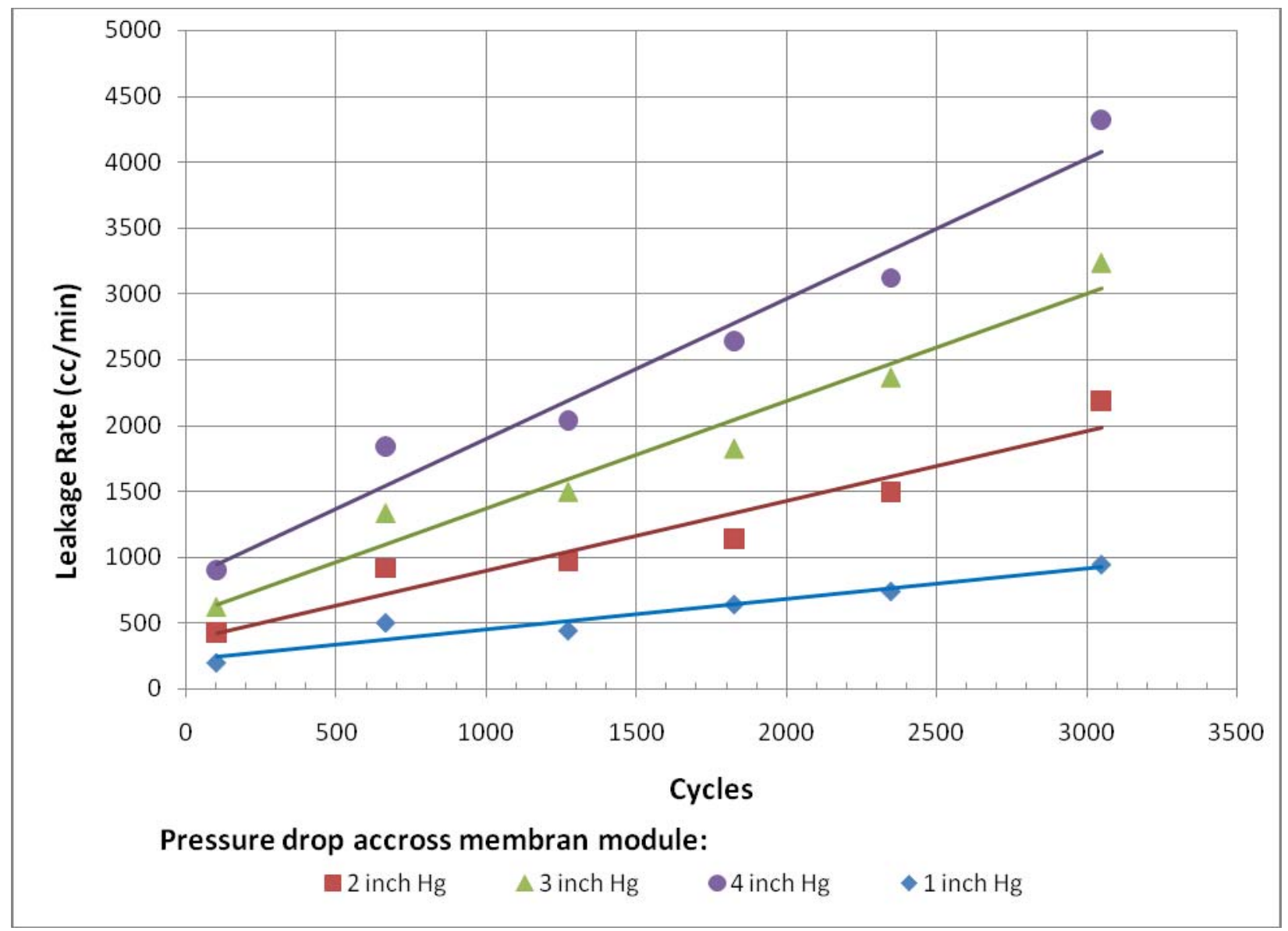

Figure 11-4. Membrane Module Air Leakage Rate

The 5000 cycles of testing for the planar membrane module were completed. In the last quarterly report, the test data for 3300 cycles was presented. The initial 150 cycles were run for 4 minutes each with humid and dry air flow maintained for 2 minutes. Due to time constraints and high air usage, it was decided to decrease the total cycle time to 2 minutes. The inlet humidity during the high cycle and the low cycle was maintained at about 50 and 0 percent respectively. The test data for a typical 2-minute cycle is shown in Figure 11-5 and Figure 11-6. The water transfer rate during each cycle was very consistent throughout the cycling test. 


\section{Honeywell}

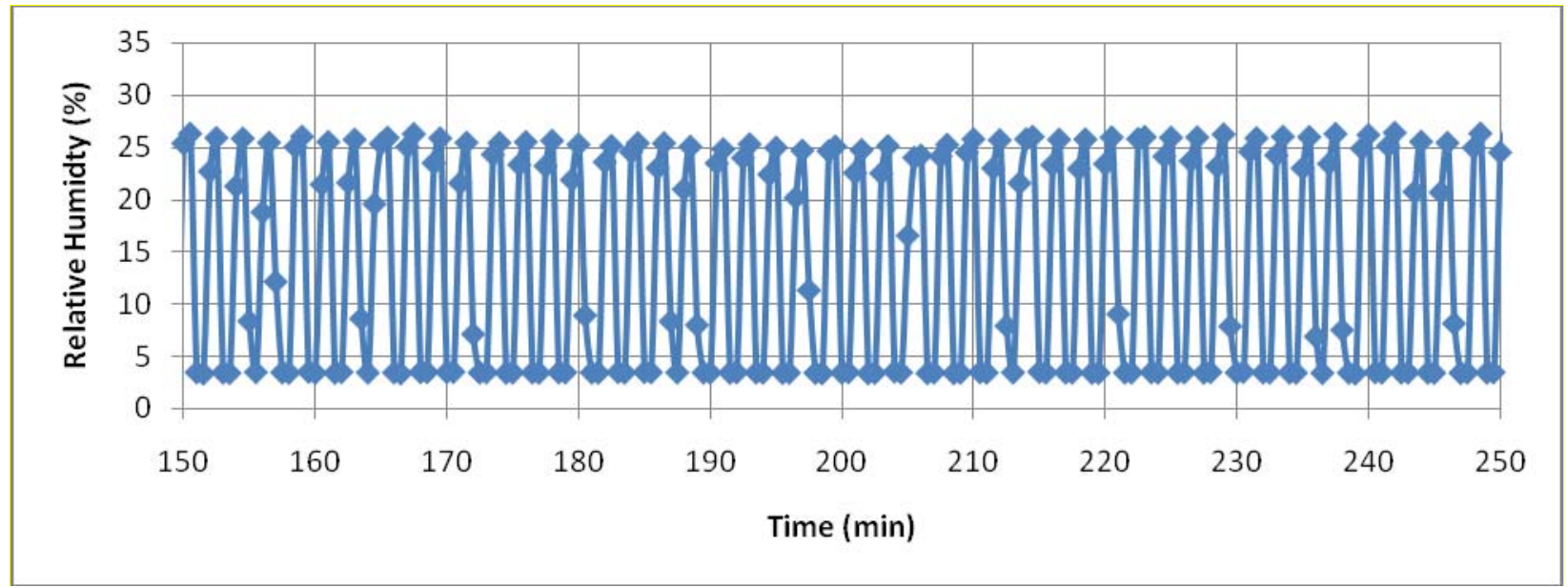

Figure 11-5. Typical 2-Minute Humidity Cycles

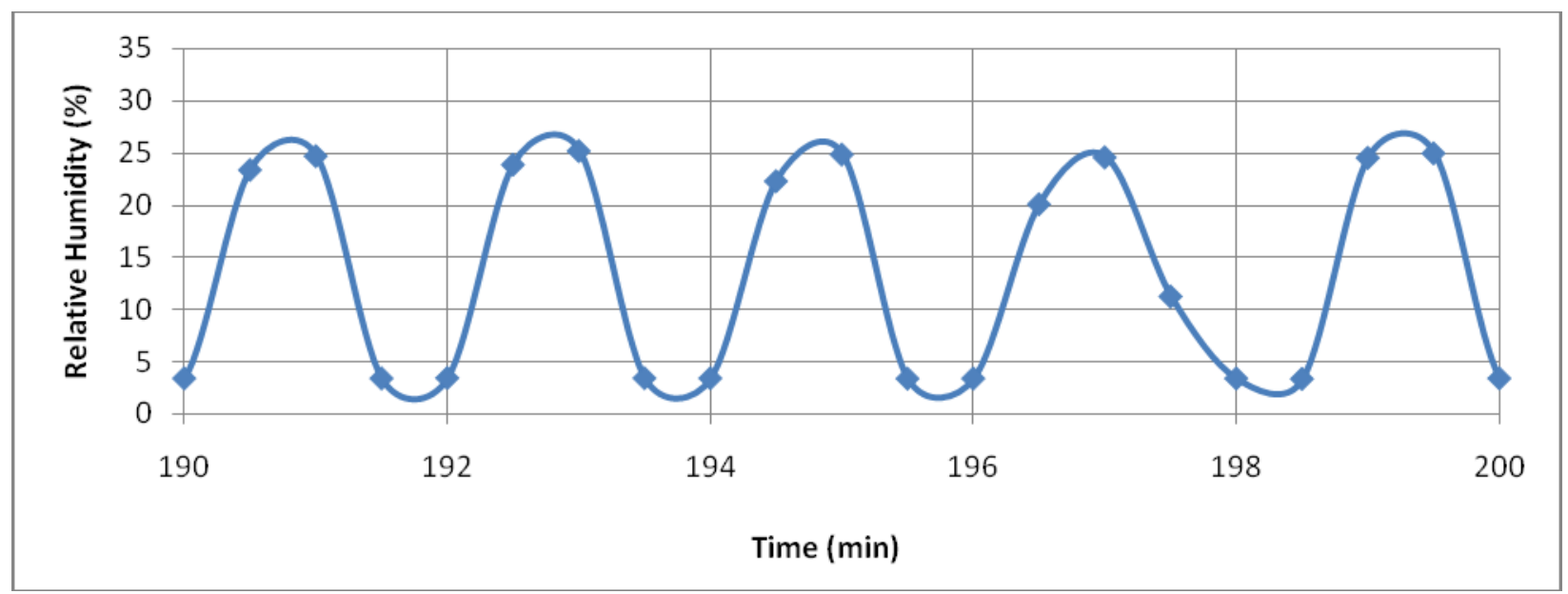

Figure 11-6. Typical 2-Minute Humidity Cycles

The leakage across the membrane module was measured periodically. The leak check was made at four pressures of 1, 2, 3 and $4 \mathrm{inHg}$. The leakage rate vs. cycle for 5000 cycles is presented in Figure 11-7. The leakage increase was linear with the number of cycles. Even though the leakage increased, it was still within the acceptable limit as confirmed by the supplier (dPoint Technology, Inc.). The reason for the steady increase in leakage could not be explained, particularly since unit transfer efficiency was not affected. 
Honeywell

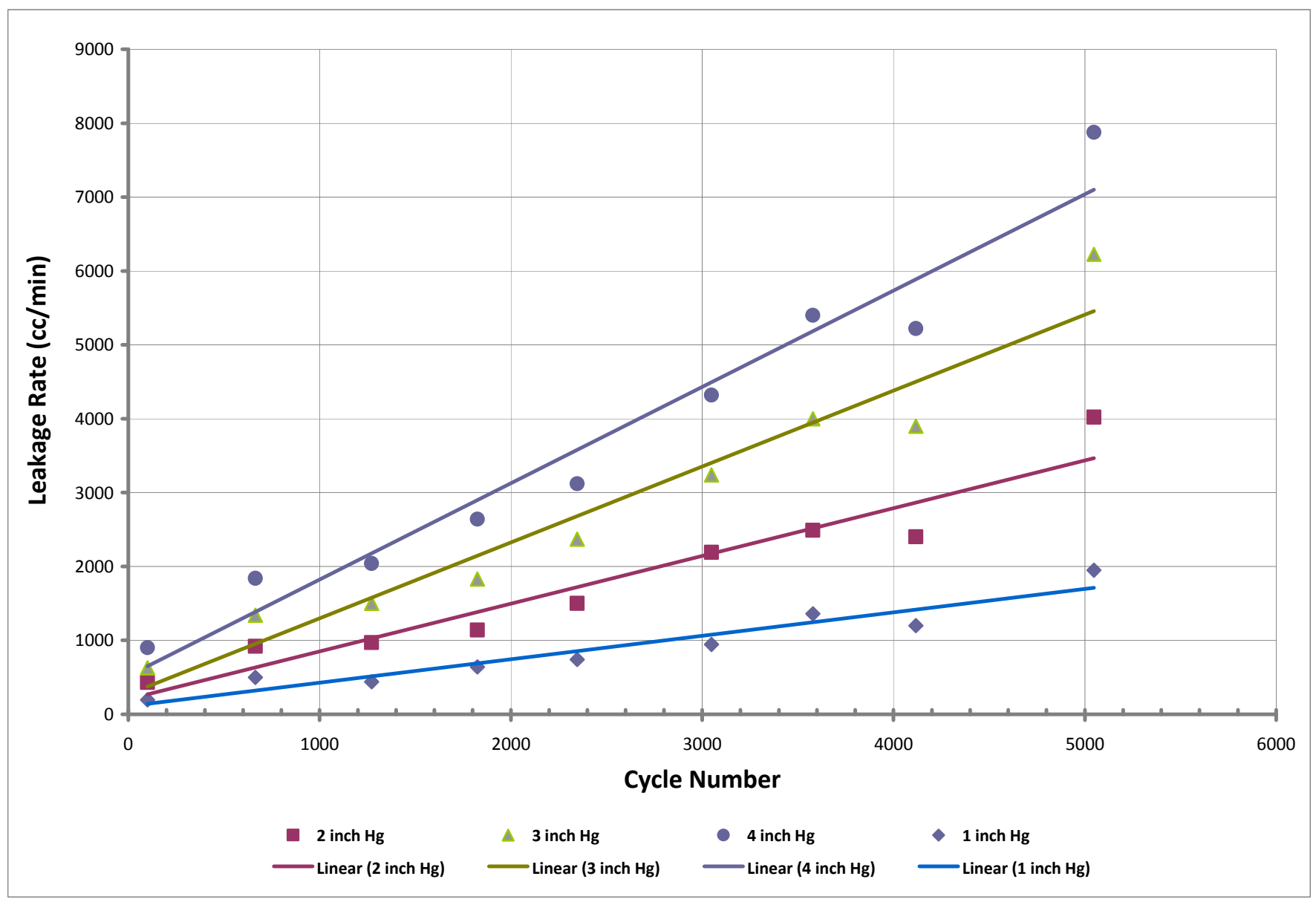

Figure 11-7. Membrane Module Air Leakage Rate

The enthalpy wheel was installed in the test stand as shown in Figure 11-8. Over 5000 cycles were run on the enthalpy wheel, as shown in Figure 11-9. The leakage rate across the enthalpy wheel two circuits was measured periodically at seven different pressures. The leakage rate was linear at each pressure throughout the 5000 cycles. The humidity cycles were 2 minutes, identical to the one used for membrane planar module testing. 


\section{Honeywell}

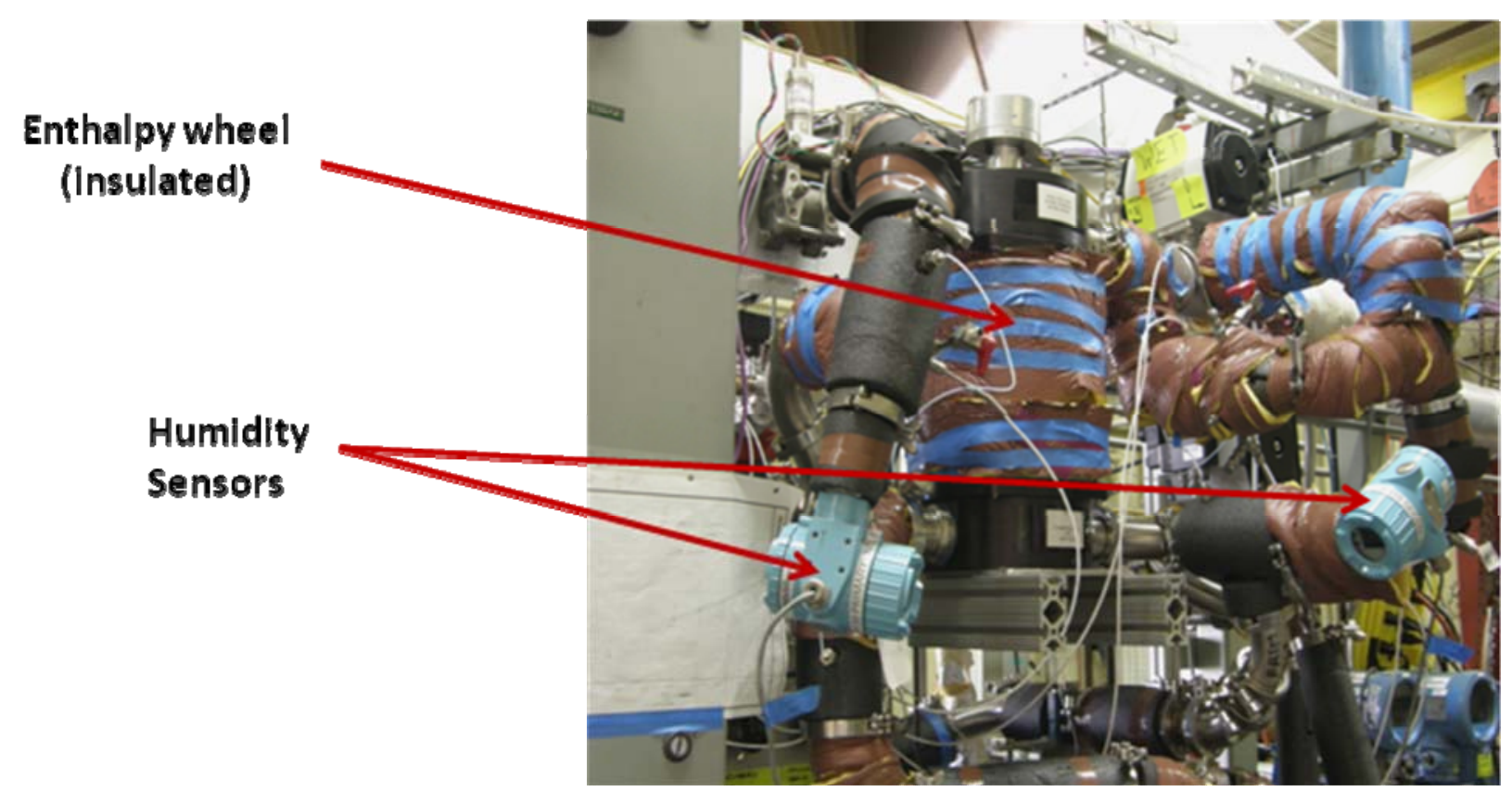

Figure 11-8. Enthalpy Wheel Installed in Test Stand

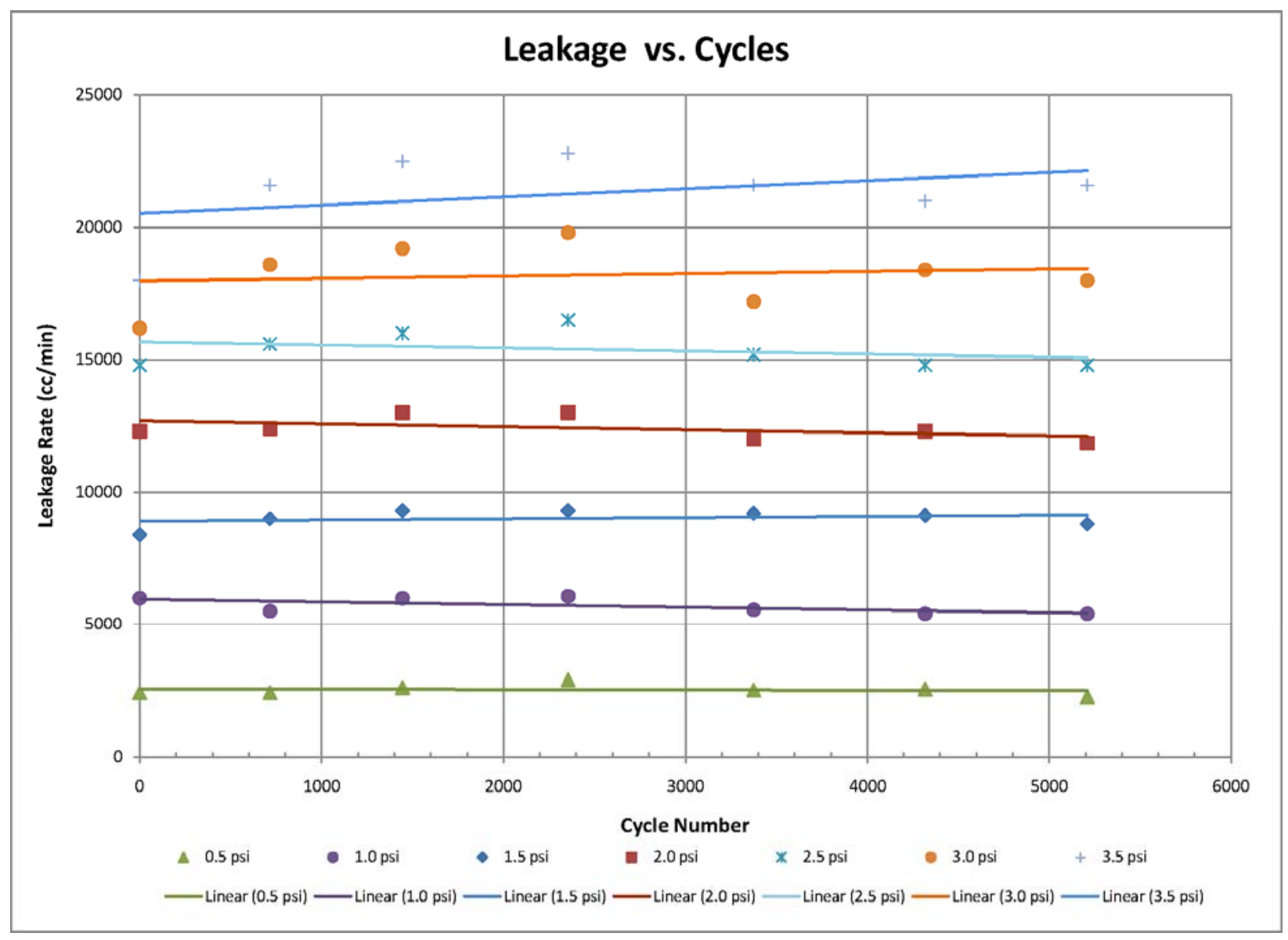

Figure 11-9. Enthalpy Wheel Air Leakage Rate

11-77418, Rev. 1

$11-8$ 


\section{Honeywell}

Appendix A. DOE Fuel Cell Thermal Management System Critical Design Review, November 14, 2008 


\section{DOE Fuel Cell \\ Thermal Management System \\ Critical Design Review \\ November 14, 2008}




\section{CDR: DOE Fuel Cell TMS}

\section{Topics For Review}

- Subscale Radiator Designs

- Subscale Performance Test Results

- Potential Issues

- Honeywell Structural Testing Of Radiators

- Value Function Validation

- Full Scale Radiator Design

- Full Scale Radiator Selection Recommendation 
Subscale Louver Radiators P/n 792960 -1 \& -2

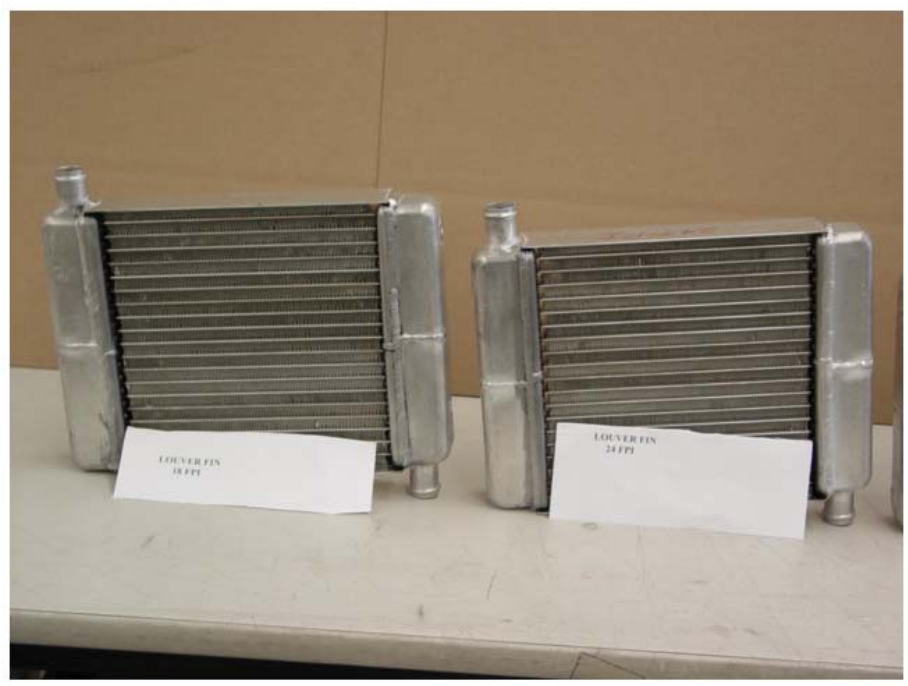

- Core Dimensions: $L h=9$ in. $L c=1.26$ in. $L n=9$ in.

- Cooling Air Passages $=20$

- Tubes $=19$ 


\section{Honeywell}

Subscale Multi Channel Radiators P/n $792960-3$ \& -4

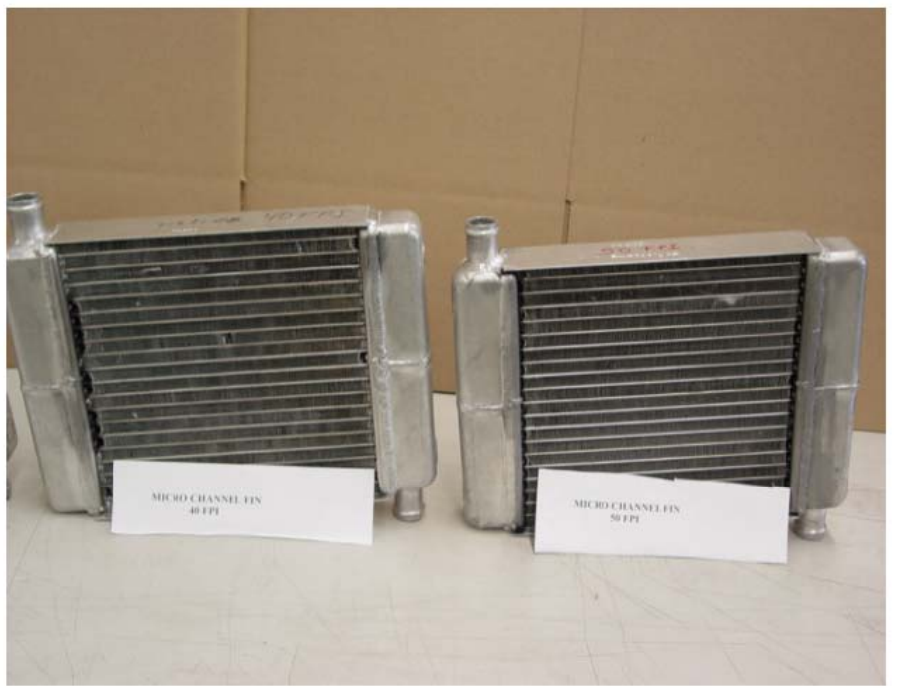

- Core Dimensions: $\mathrm{Lh}=9$ in. $\mathrm{Lc}=1.26 \mathrm{in} . \mathrm{Ln}=9 \mathrm{in}$.

- Cooling Air Passages $=20$

- Tubes $=19$ 


\section{Key Fin Characteristics}

- Louver Fins

- 18 \& 24 Fins per Inch

- 0.384 in. $(9.75 \mathrm{~mm})$ Fin Height

- 0.004 in. $(0.10 \mathrm{~mm})$ Fin Thickness

- 21 Degree Louver Angle

- 0.334 in. $(8.48 \mathrm{~mm})$ Louver Length
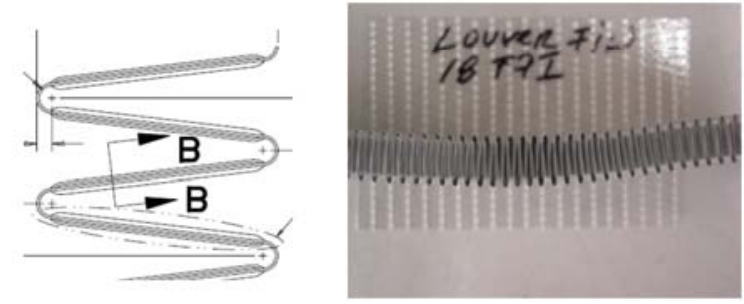

- Multi Channel Fins

- 40 \& 50 Fins per Inch

- 0.384 in. $(9.75 \mathrm{~mm})$ Fin Height

-0.003 in. $(0.08 \mathrm{~mm})$ Fin Thickness
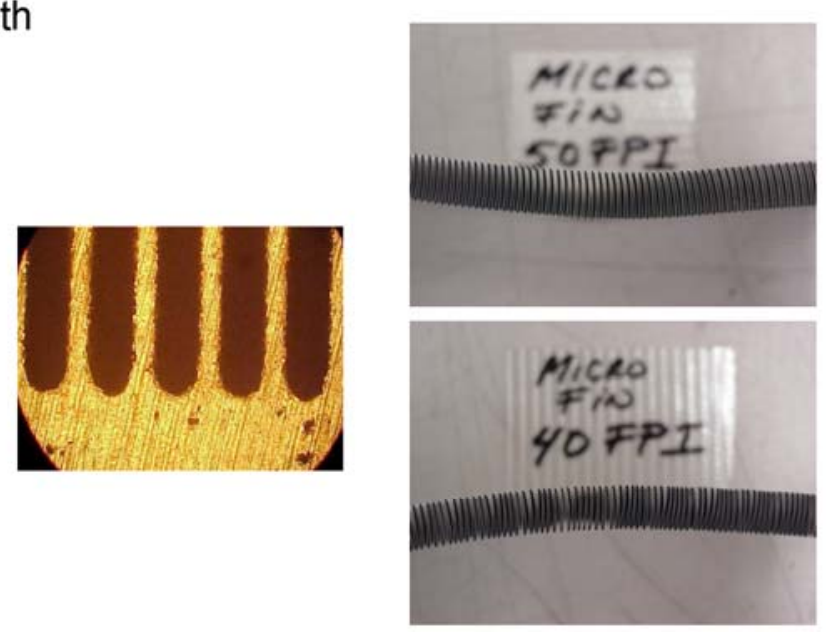


\section{Honeywell}

This page has been deleted because it was deemed to contain Honeywell Confidential information. 


\section{Honeywell}

Subscale Louver Fin Comparison: 18fpi vs 24fpi

Subscale $9 \times 9$ inch $24 p$ fi Louver Fin

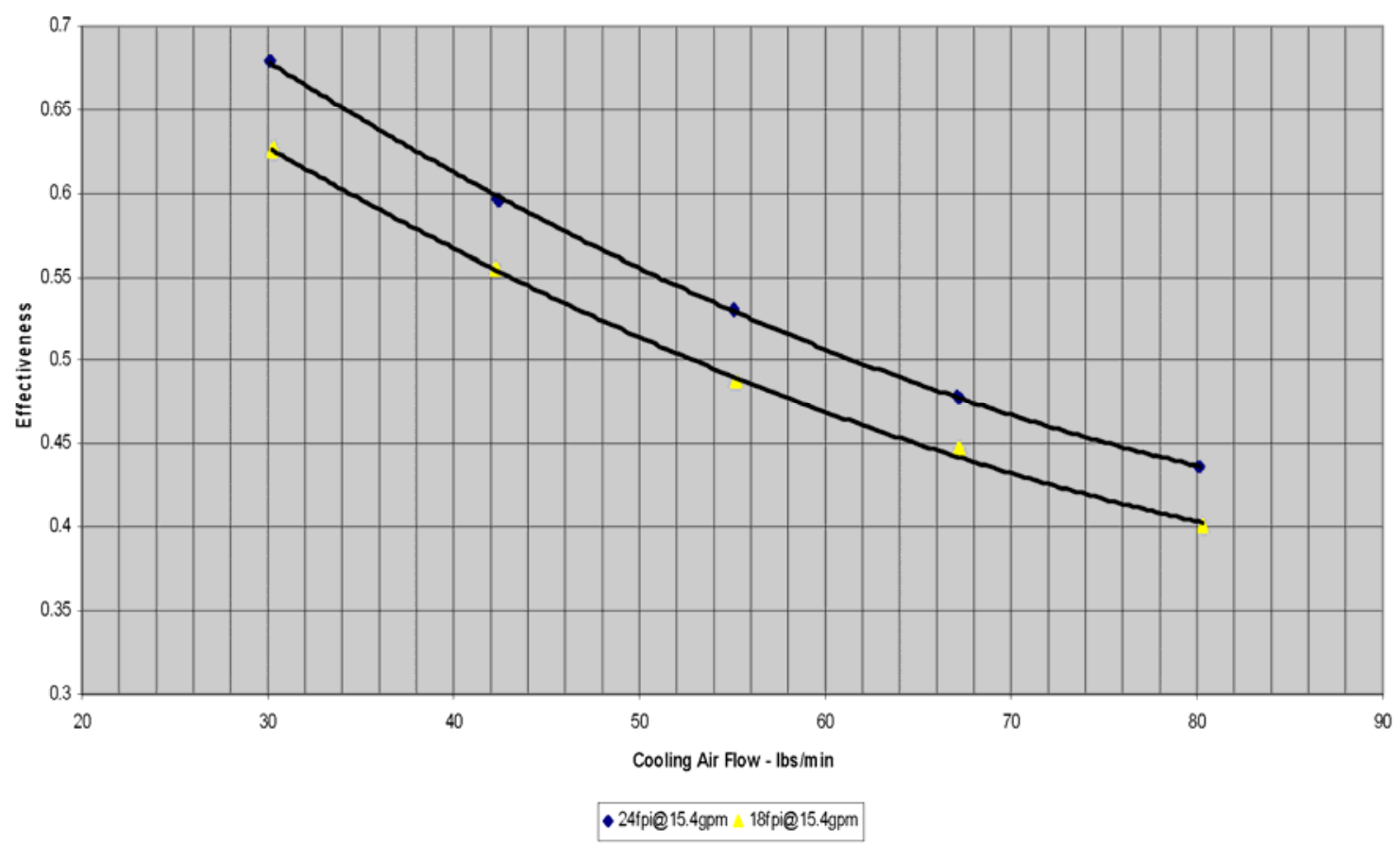

24fpi Louver Provides Highest Heat Transfer 


\section{Honeywell}

\section{Subscale Micro Fin Comparison: 40fpi vs 50fpi}

Subscale Micro Fin Comparison: 40fpi vs 50fpi

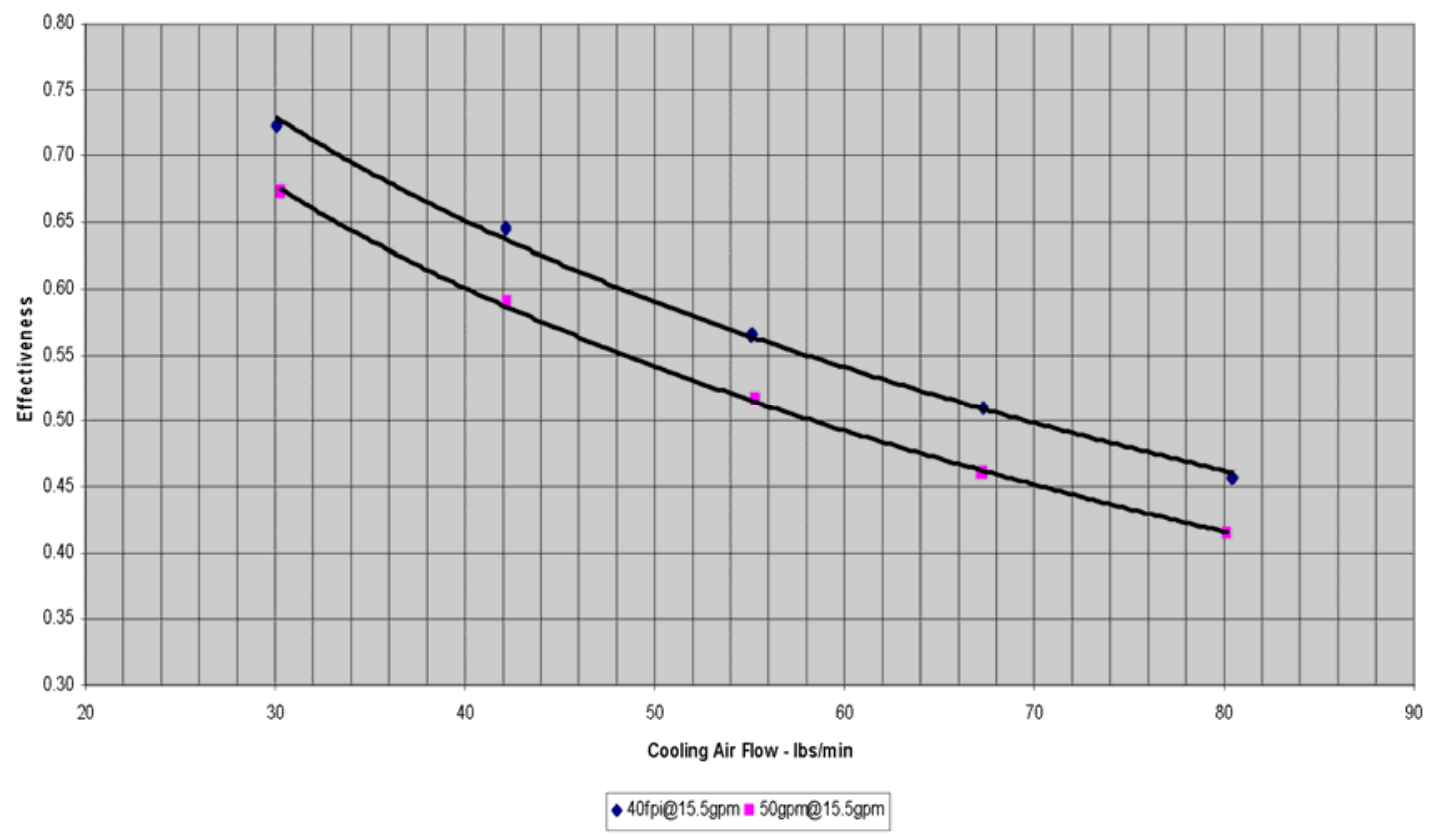

The Lower Density Micro Fin Performs Better 
Subscale Micro Fin Comparison: 40fpi vs 50fpi

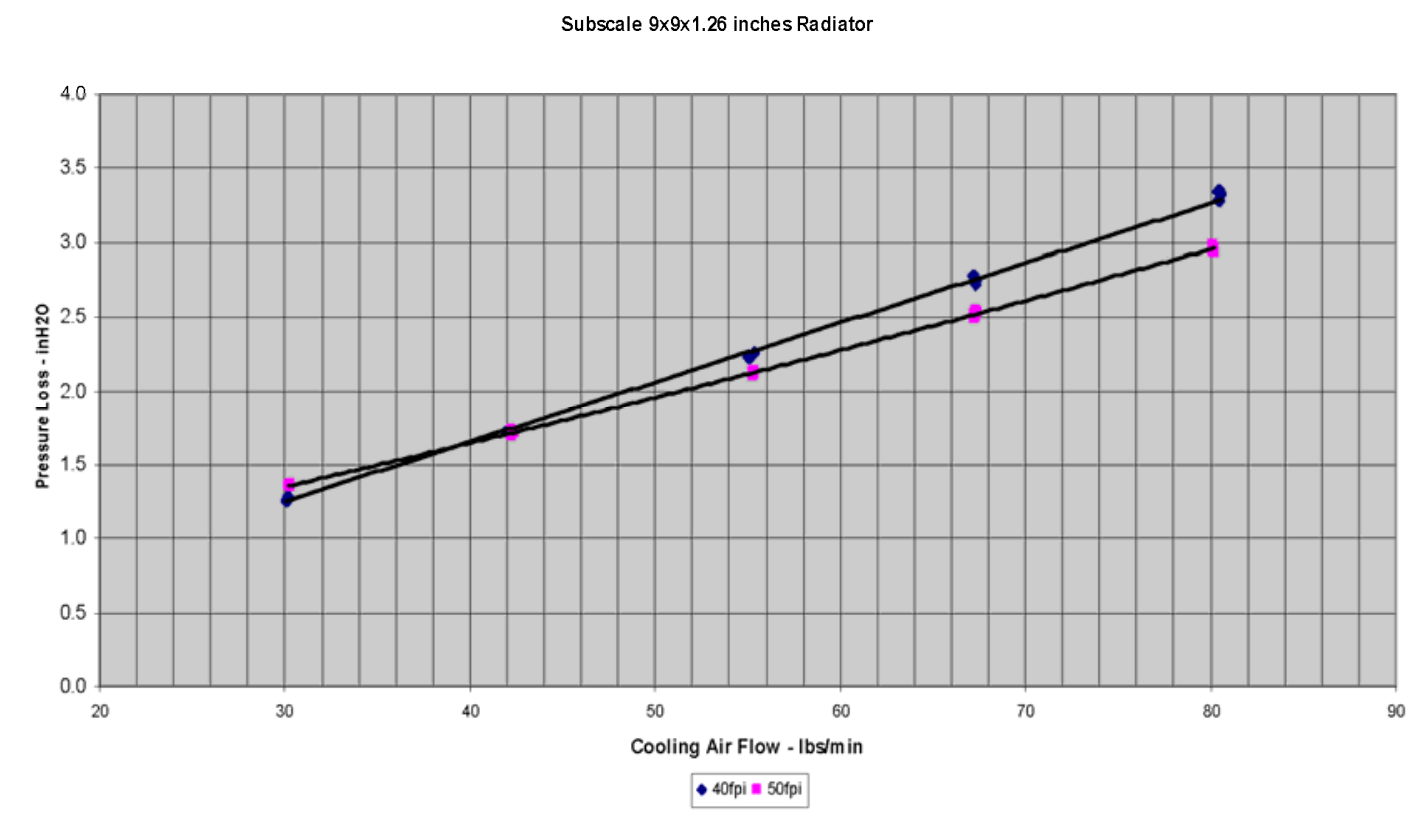

Pressure Loss Questionable: Impacted by Fin Aspect Ratio 
Honeywell

Subscale Fin Comparison: 18fpi vs 40fpi

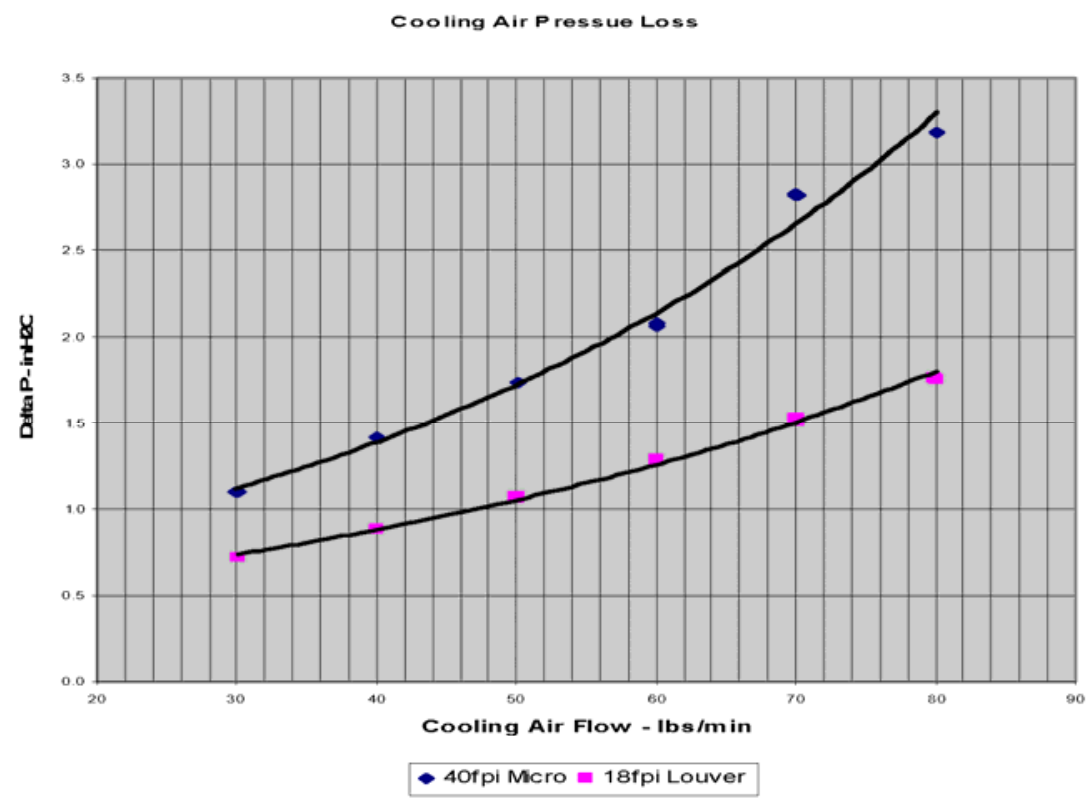

40fpi Provides Highest Heat Transfer, But More Fan Power 


\section{Honeywell}

Subscale Coolant Pressure Loss

Subscale $9 \times 9 \times 1.26$ inches

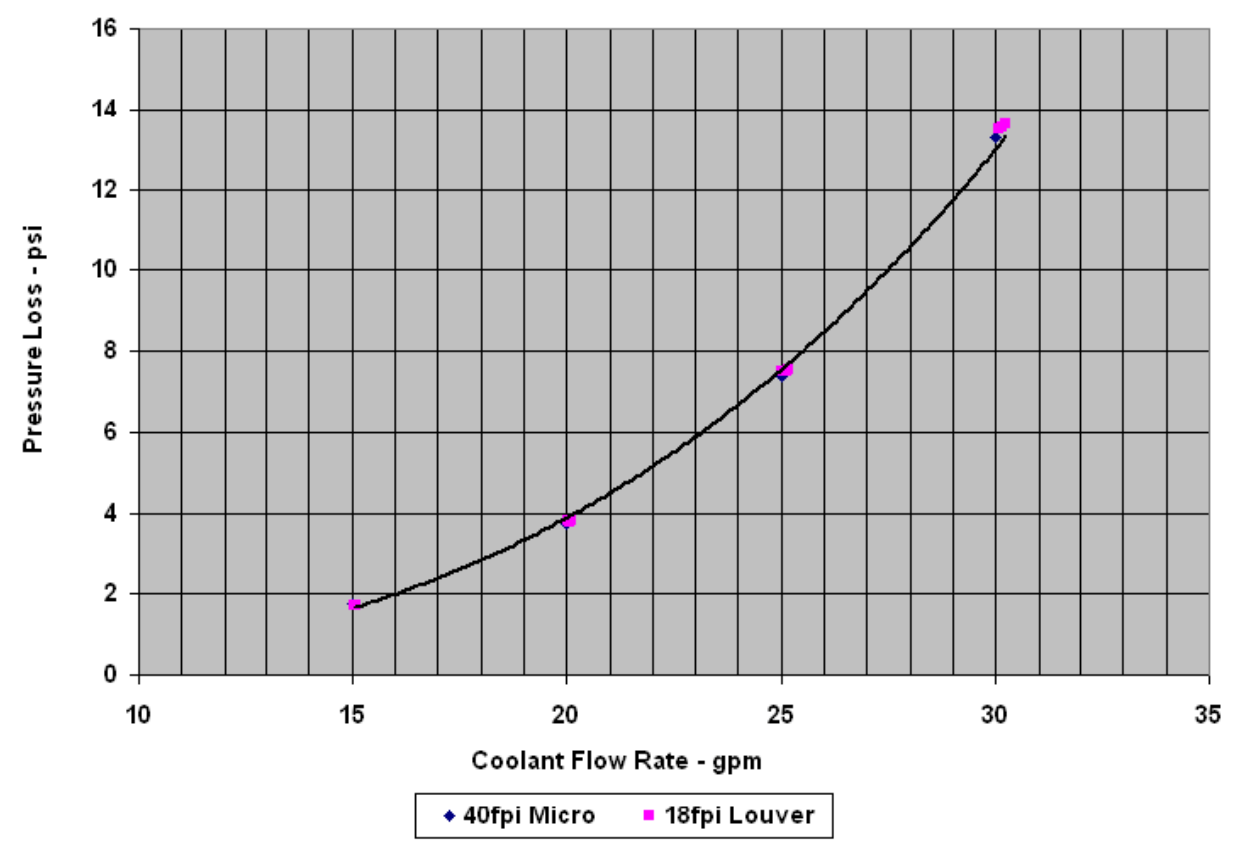

Coolant Pressure Loss Consistent Between Units 
Louver Fin and Micro Fin Compared at Design Coolant Flow Subscale Performance: Louver vs Micro at Design Coolant Flow (19.3gpm)

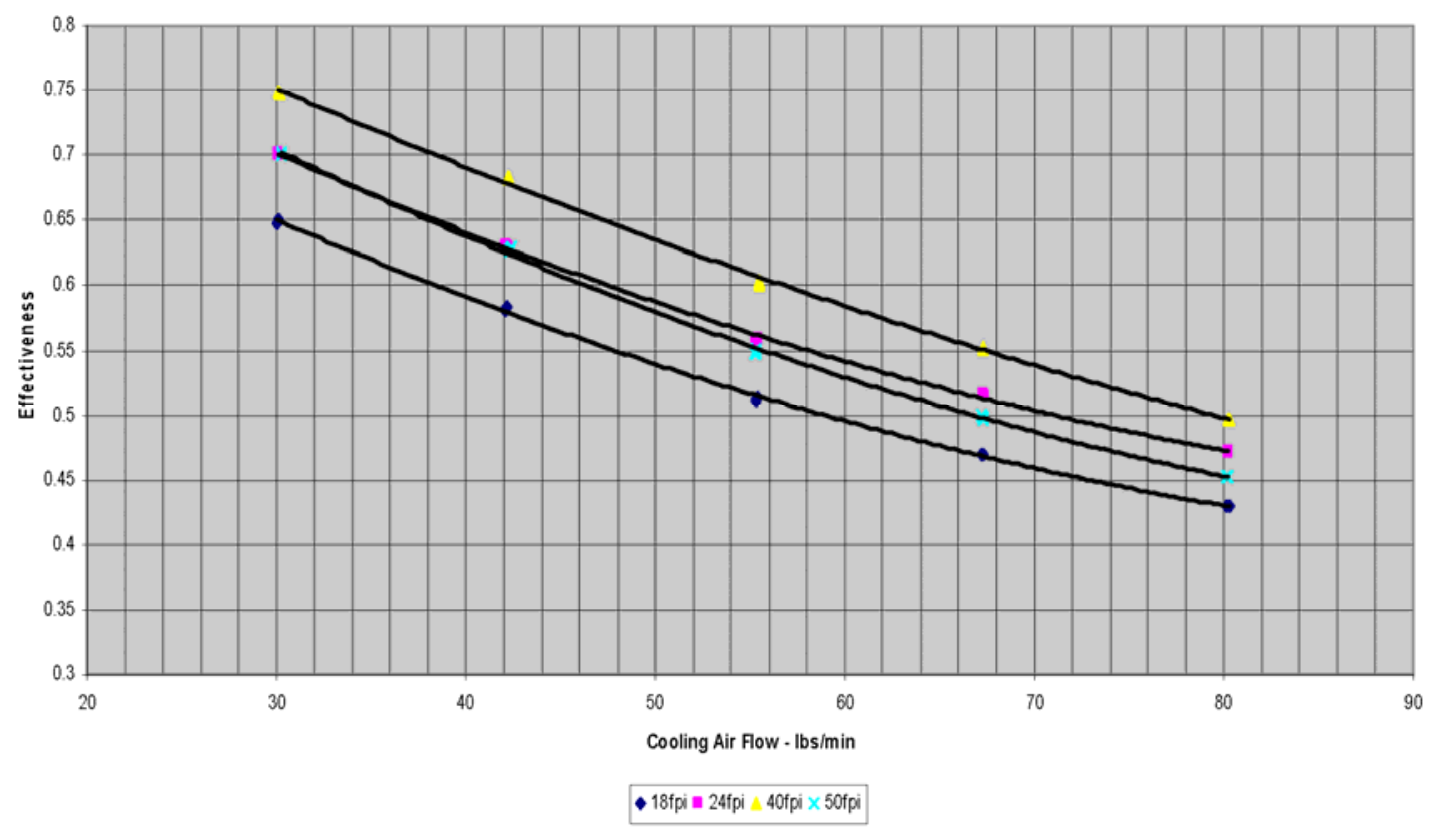

40 fpi Micro Channel Displays Best Heat Transfer Performance 


\section{Honeywell}

\section{Potential Issues}
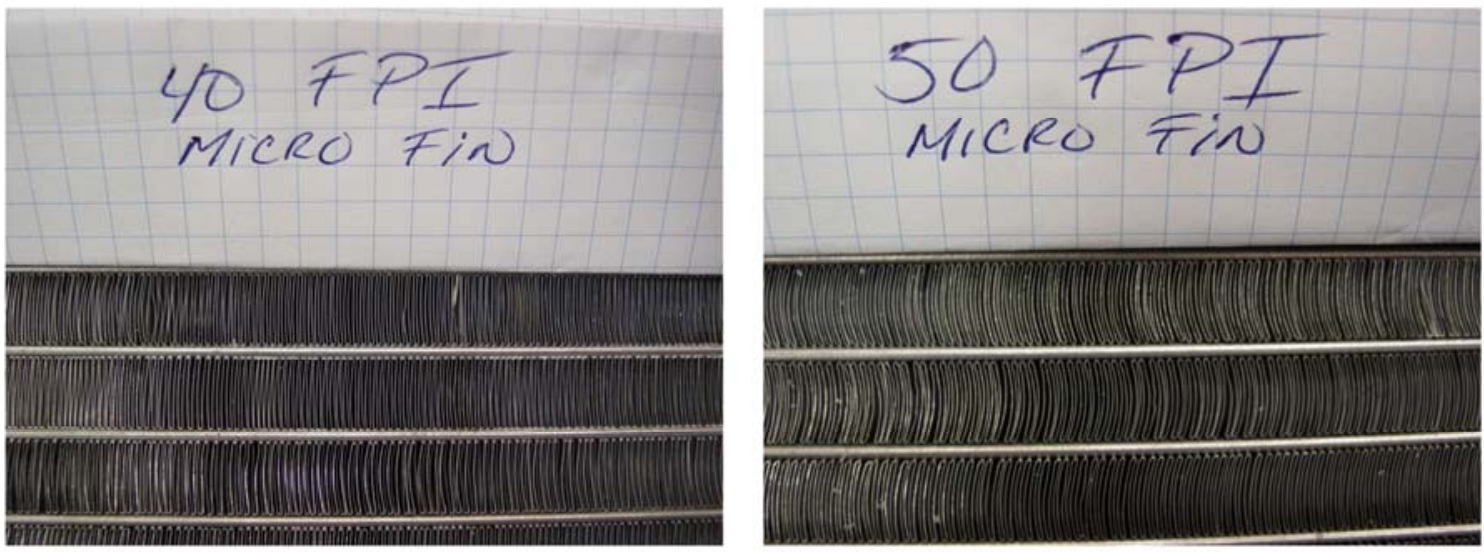

50 fpi Micro Channel Performance Degradation :

-Bulginess (Reference London, A. L. ASME, Series A, Vol. 92, 1970).

-Non-uniform Fin Spacing (Reference Mondt, J. R. Journal of Engineering Power, October 1977).

Fin Aspect Ratio Can Have A Significant Impact On Design 


\section{Honeywell}

This page has been deleted because it was deemed to contain Honeywell Confidential information.

11-77418, Rev. 1 
Honeywell

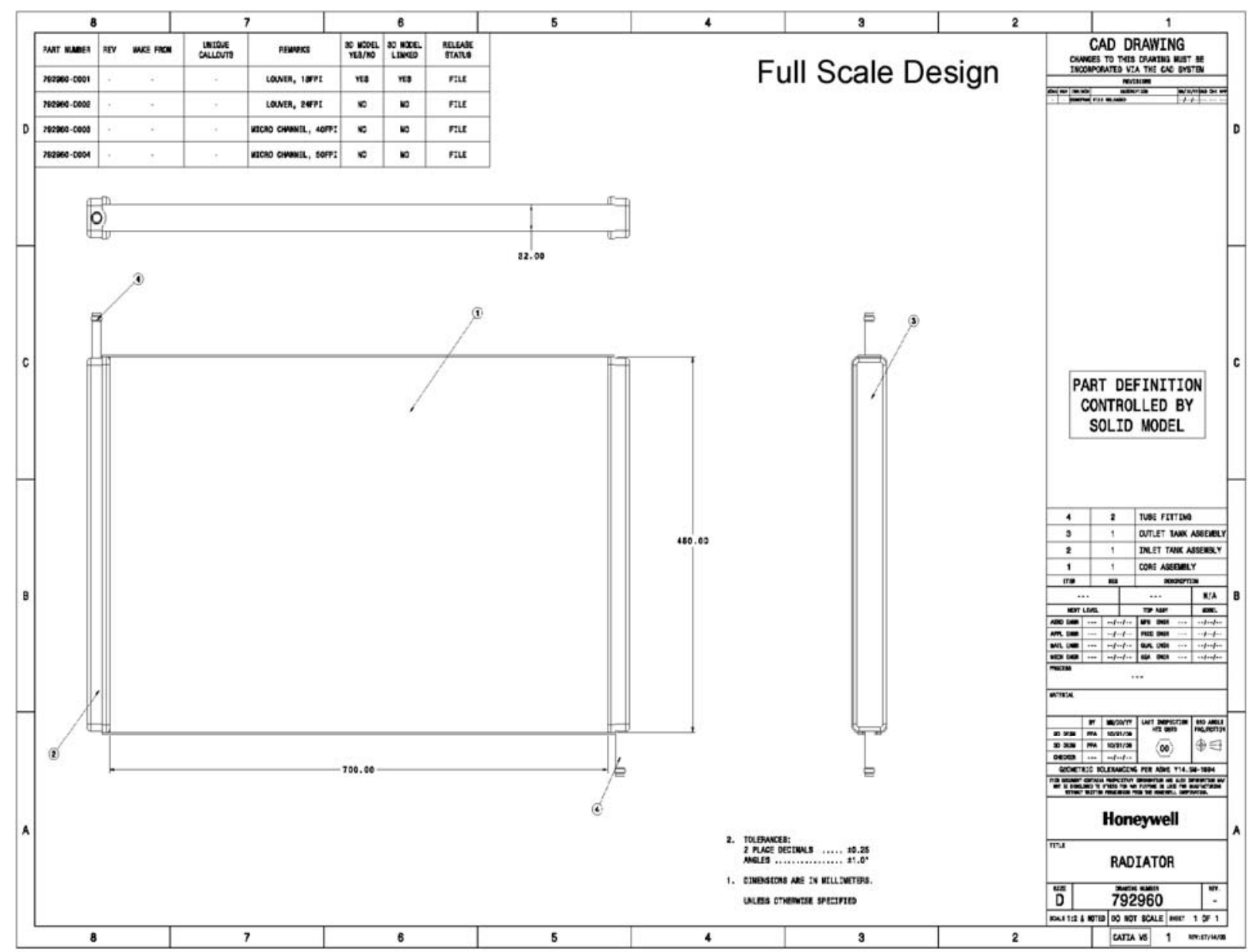

11-77418, Rev. 1

A-15 


\section{Radiator Test Data \\ Comparison With Performance Prediction Model}

\begin{tabular}{l|c|c|}
\cline { 2 - 3 } Fin & \multicolumn{2}{|c|}{ Test As \% Of Calculated } \\
\cline { 2 - 3 } L18 & P Air & JP Coolant \\
\cline { 2 - 3 } L24 & 109 & 245 \\
MC40 & 78 & 232 \\
MC50 & 196 & 241 \\
\cline { 2 - 3 } & 111 & 225 \\
\hline
\end{tabular}

\begin{tabular}{|c|}
\hline UA Margin \\
To Match Q \\
\hline 0.0000 \\
0.1000 \\
0.1234 \\
0.6000 \\
\hline
\end{tabular}

11-77418, Rev. 1 


\section{Value Function Comparison}

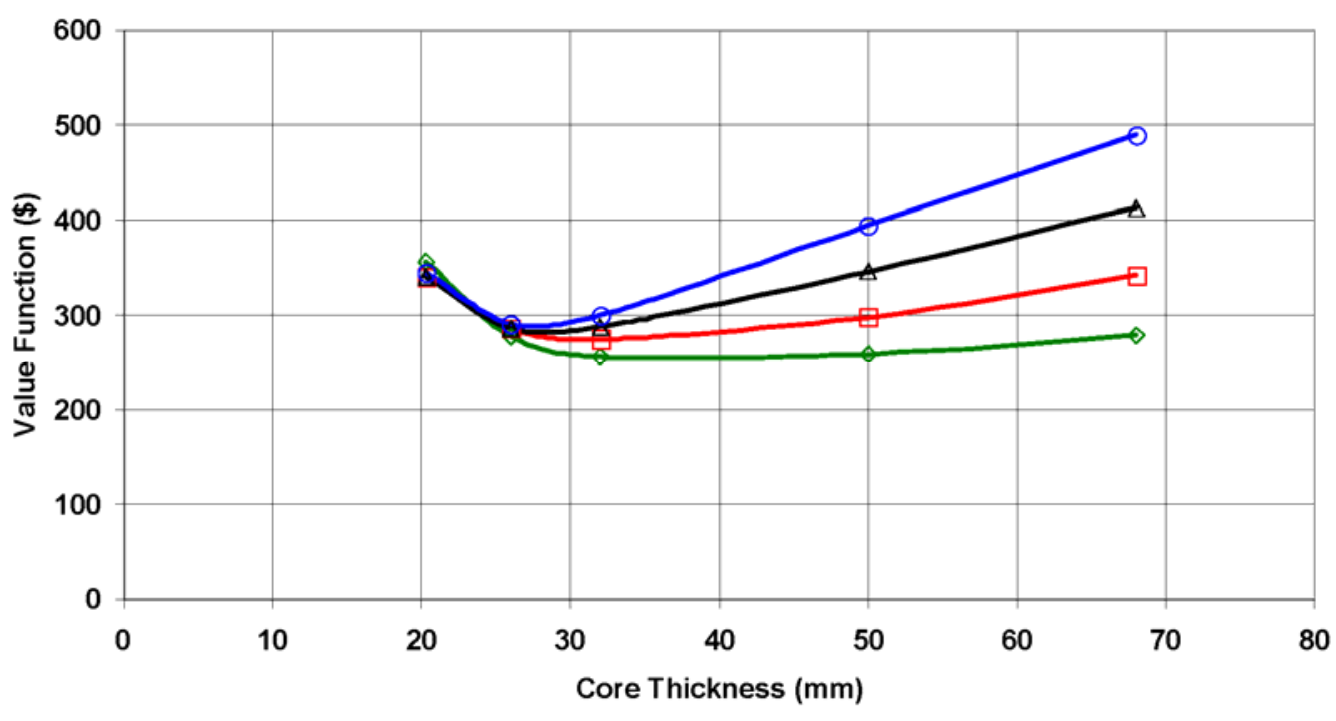

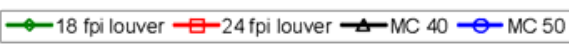

Air Pressure Drop For MC40 Corrected To Match Test Data 


\section{Value Function Comparison}

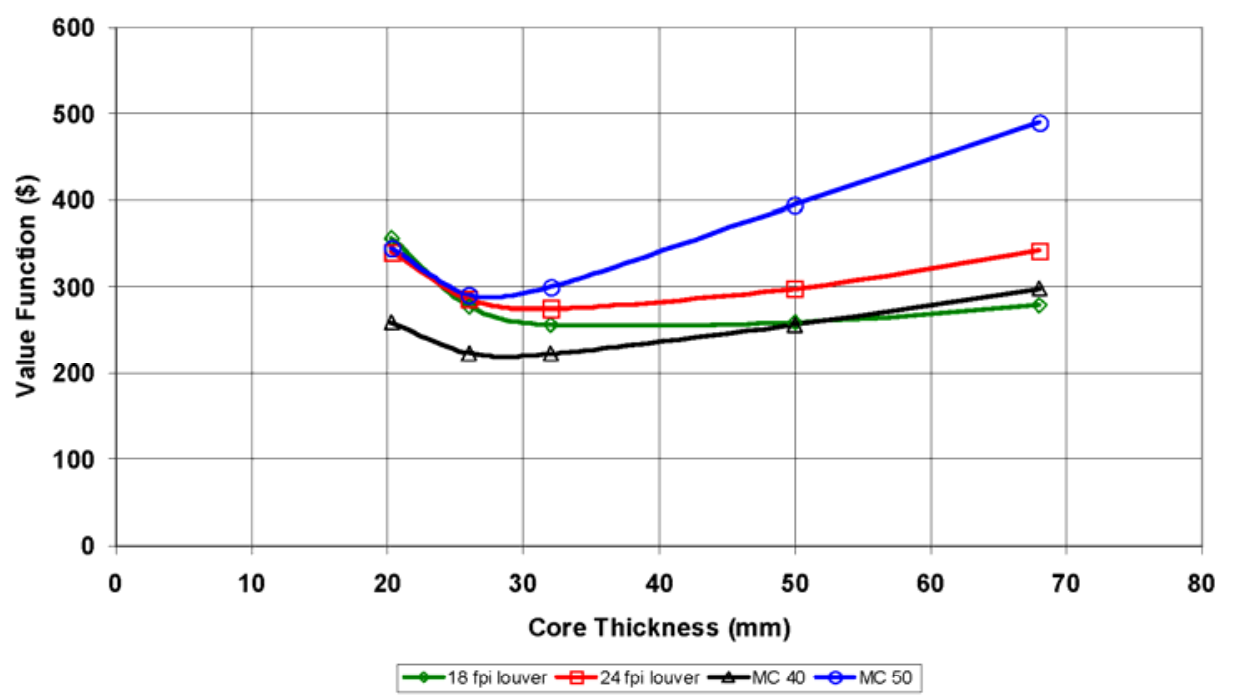

Air Pressure Drop For MC40 Is Calculated Value

11-77418, Rev. 1

A-18 


\section{Honeywell}

This page has been deleted because it was deemed to contain Honeywell Confidential information. 


\section{Honeywell}

Appendix B. Development of Thermal and Water Management System for PEM Fuel Cell FY2011 Plan 


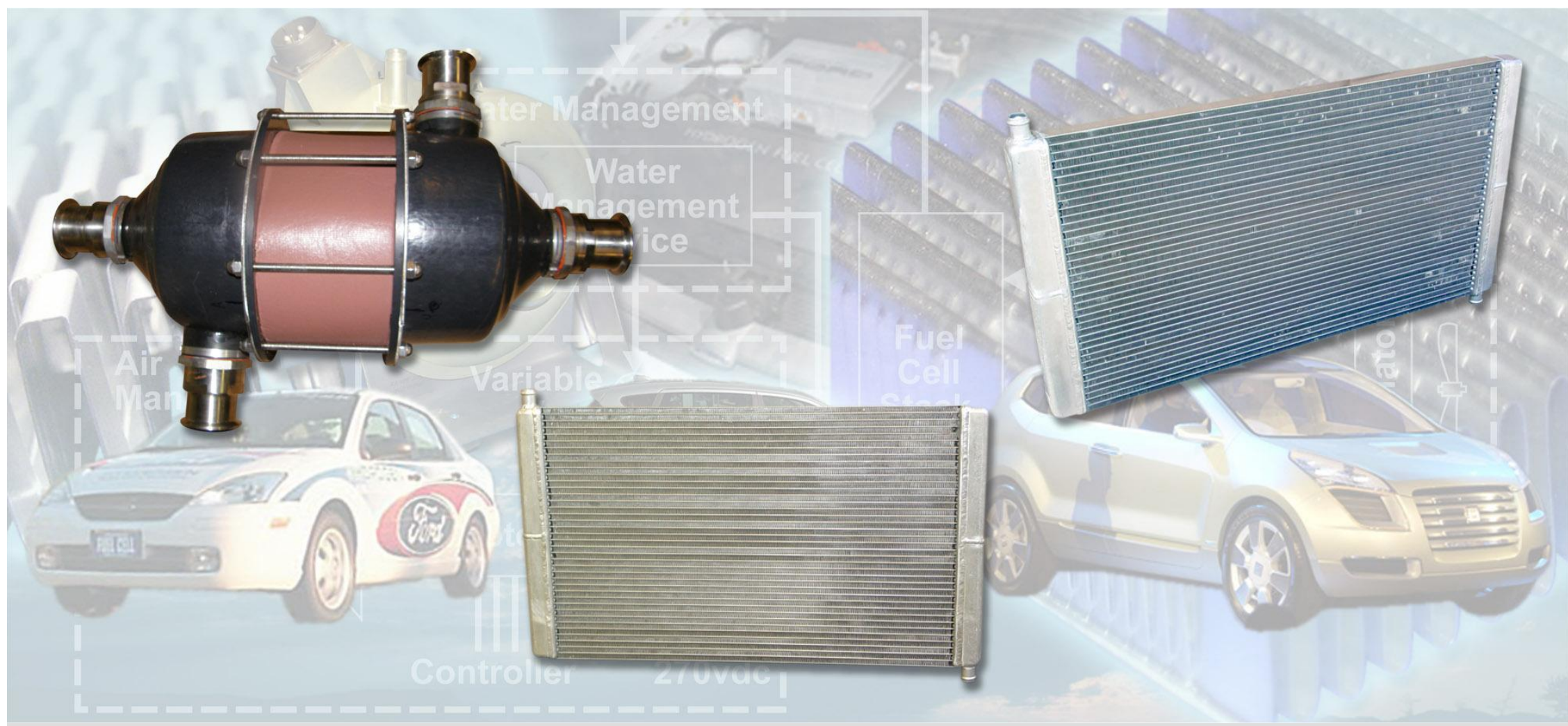

\section{Development of Thermal \& Water Management System for PEM Fuel FY2011 Plan}

Zia Mirza

Dec. 9, 2010

This document is controlled by U.S. Export Control laws and may not be transferred, transmitted, or shared with any other country or citizen thereof, without the prior written approval of the U.S. Department of State. Diversion contrary to U.S. export laws and regulations is prohibited. The recipient without the prior written approval of the U.S. Department of State. Diversion contrary to U.S. export laws and regulations is prohibited. The recipient
must obtain approval from the U.S. Department of State prior to exporting such data, including any disclosure to foreign nationals in the U.S or abroad. must obtain approval from the U.S. Department of State prior to exporting such data, including any disclosure to foreign nationals in the U.S or abroad.
This document is the property of Honeywell International Inc. It is furnished for evaluation purposes and may not be duplicated, used, or disclosed in whole or in part for any other purpose without the prior written permission of Honeywell International Inc. 


\section{Agenda}

- Overview

- Objectives

- Accomplishments by Fiscal Year

- Thermal Management Program Summary

- PEM Fuel Cell Humidification systems

- Go-forward plan 


\section{Program Overview}

\section{Budget}

- Total project funding

- DOE share

- Honeywell

- Total

- DOE funding to-date

- Honeywell share

- Total

- Remaining DOE funding

- Honeywell share

- Total funds available for FY2011

\section{Timeline}

- Project start

- Program stopped

- Program re-start

FY03

FY05/FY06

2007

$\$ 812 \mathrm{~K}$

$\$ 4,062 K$

$\$ 3,010 \mathrm{~K}$

$\$ 753 \mathrm{~K}$

$\$ 3,763 \mathrm{~K}$

\section{Partners}

- US Department of Energy

- Argonne National Lab

$\$ 240 K$

$\$ 60 \mathrm{~K}$

- Freedom CAR Tech Team 


\section{Objectives for Water \& Thermal Management}

- Improve PEM fuel cell performance and life by maintaining the humidity of inlet air stream at a high level (> 60\%)

- Eliminate need for external water source by transferring water from stack exit air stream to inlet stream

- Validate performance of full-scale humidification devices sized for $80 \mathrm{~kW}$ PEM fuel cell

- Test Emprise enthalpy wheel

- Test Perma Pure membrane modules

- Test planer membrane module

- Performance testing at sub-ambient conditions

- Design, build and test high-performance full-size radiators to meet the $80 \mathrm{~kW}$ fuel cell stack cooling requirements

- Increase performance required to dissipate low-quality heat

- Optimize the weight, size, and cost 


\section{Program Accomplishments by FY}

\section{FY2003/04}

- Humidification and cooling system for $80 \mathrm{~kW}$ fuel cell developed

- System concept analysis \& radiator trade studies conducted

- Microchannel and advance louver fins were down selected

- Preliminary Design \& analysis completed

- Short stack microchannel heat exchanger was fabricated

\section{FY2008/09}

- Fuel stack radiator requirements were established and value function was developed for evaluation of various configurations

- Four different fin configuration sub-scale radiators built and tested

- Validated full-scale performance model

- Designed and built two full-scale radiators with optimized fin configurations

- Conducted testing of humidity device at low air flow rate

- Enthalpy wheel modified to reduce seal leakage

- Humidification test stand modified for higher air flow rate capability. 


\section{Accomplishments by FY (cont.)}

Accomplishments during FY2009/10

- Full scale radiators with two fin configurations were tested

- Humidification test stand was modified to accommodate high air flow rates and improved measurement accuracy

- Enthalpy wheel was modified to reduce seal leakage

- Full scale Nafion membrane humidifier was tested

- Sub scale membrane humidifier is under test

- Full scale planer membrane module was acquired for performance testing

- Submitted radiators final test report 


\section{Honeywell}

\section{Thermal Management Program Summary}

- Thermal Management Program was successfully completed

- Four sub-scale radiators with different fins configuration built and tested

- Performance model validated, manufacturability lesson learned

- Two down-select fin configurations; full-scale radiators built

- Test results validated the performance model

- Test results were used in PEM fuel cell system model by Argonne National Lab.

- Honeywell Radiators estimated cost of $\$ 50$ compared well with independent consultant estimates of $\$ 58$

- Submitted radiators final test report 


\section{Honeywell}

\section{Full-Scale Radiators}

Size of the radiator: 27.6 " width, $17.7^{\prime \prime}$ height, and 1.3" depth.

Estimated weight of full-scale louver and microchannel radiator (with plastic tanks) will be 10 and 13 lbs respectively

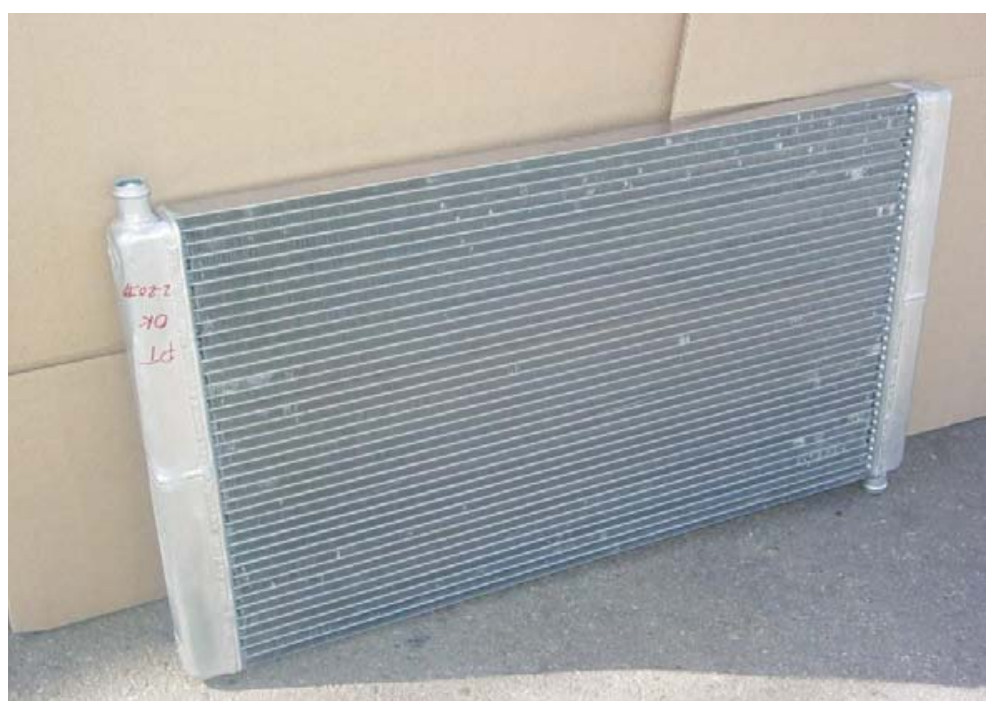

40 fins/in. Microchannel Fins

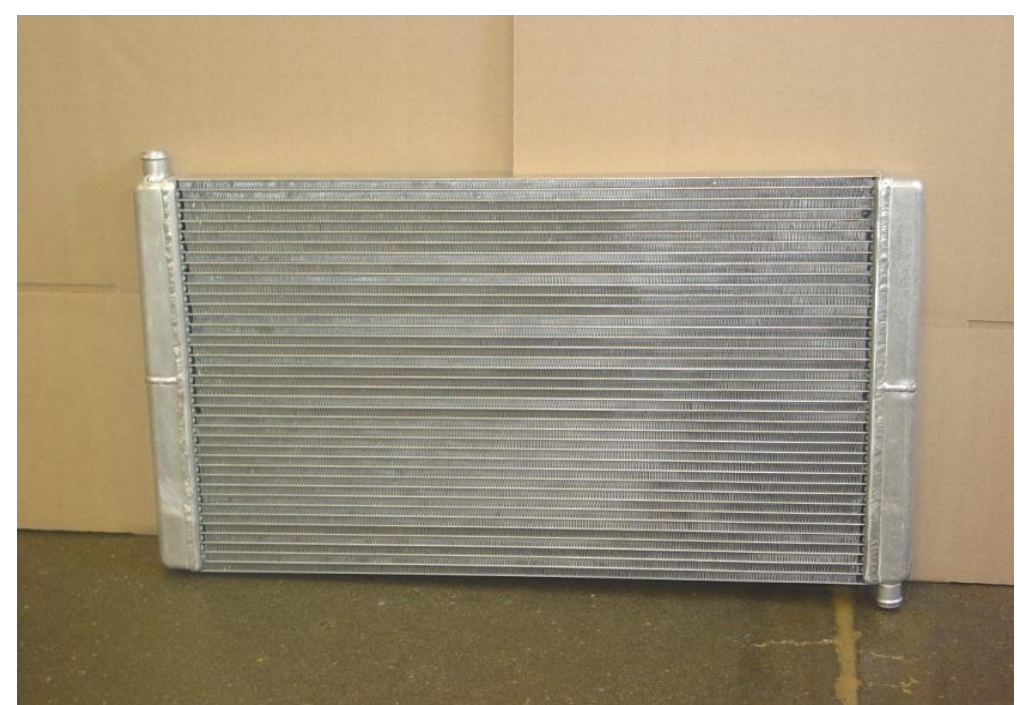

18 fins/in. Louver Fins

\section{Full size microchannel radiators built successfully}




\section{PEM Fuel Cell Humidification Options}
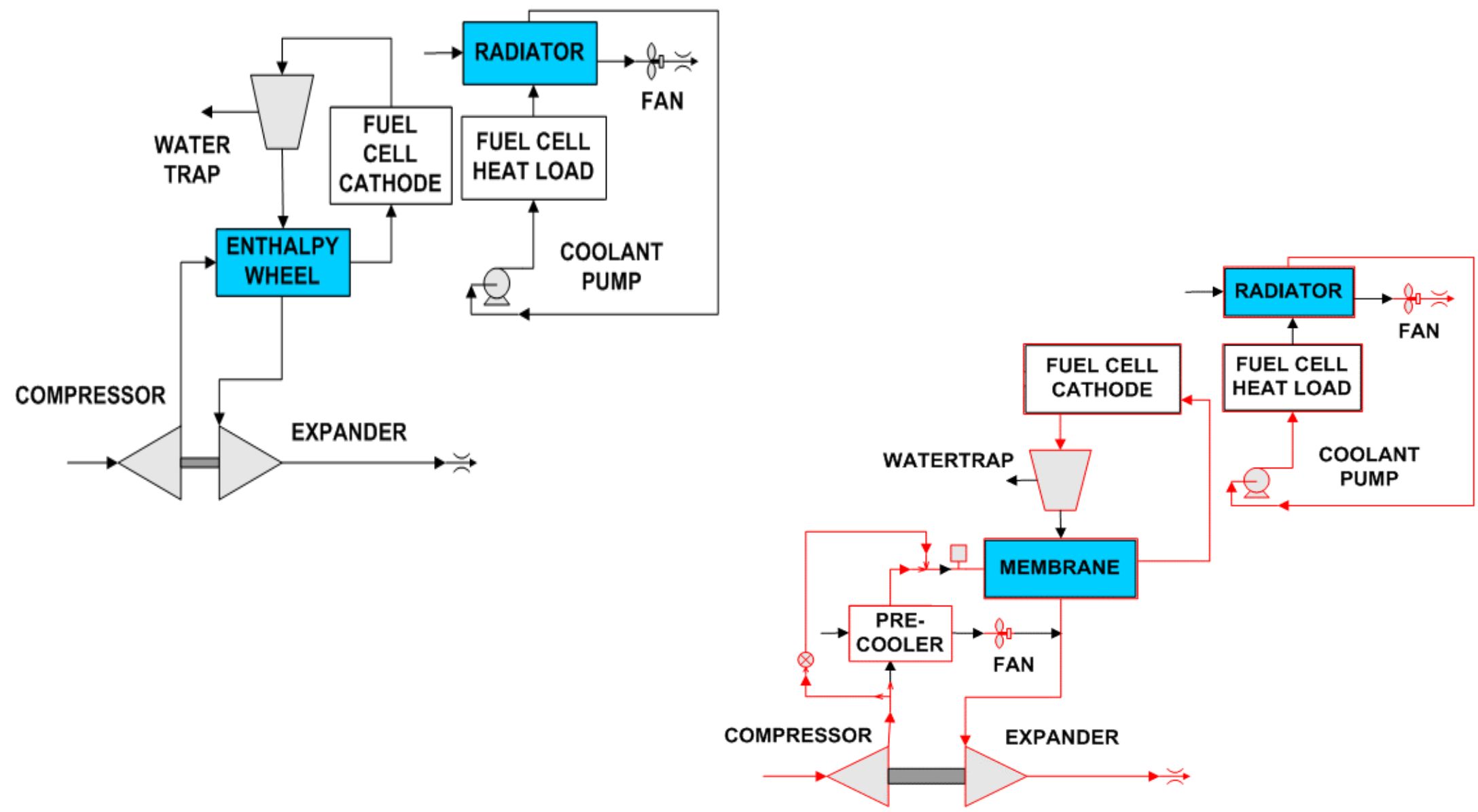


\section{Enthalpy Wheel}

Enthalpy Wheel supplied by Emprise, Kennesaw, GA

- Water adsorbed and de-sorbed in a rotating wheel

- Power: $<100 \mathrm{~W}$, Seal leakage $<1 \%$ of process air

- Volume $171 \mathrm{cu}$ in, weight $17 \mathrm{Kg}$ and size 8" Dia, 6" length wheel
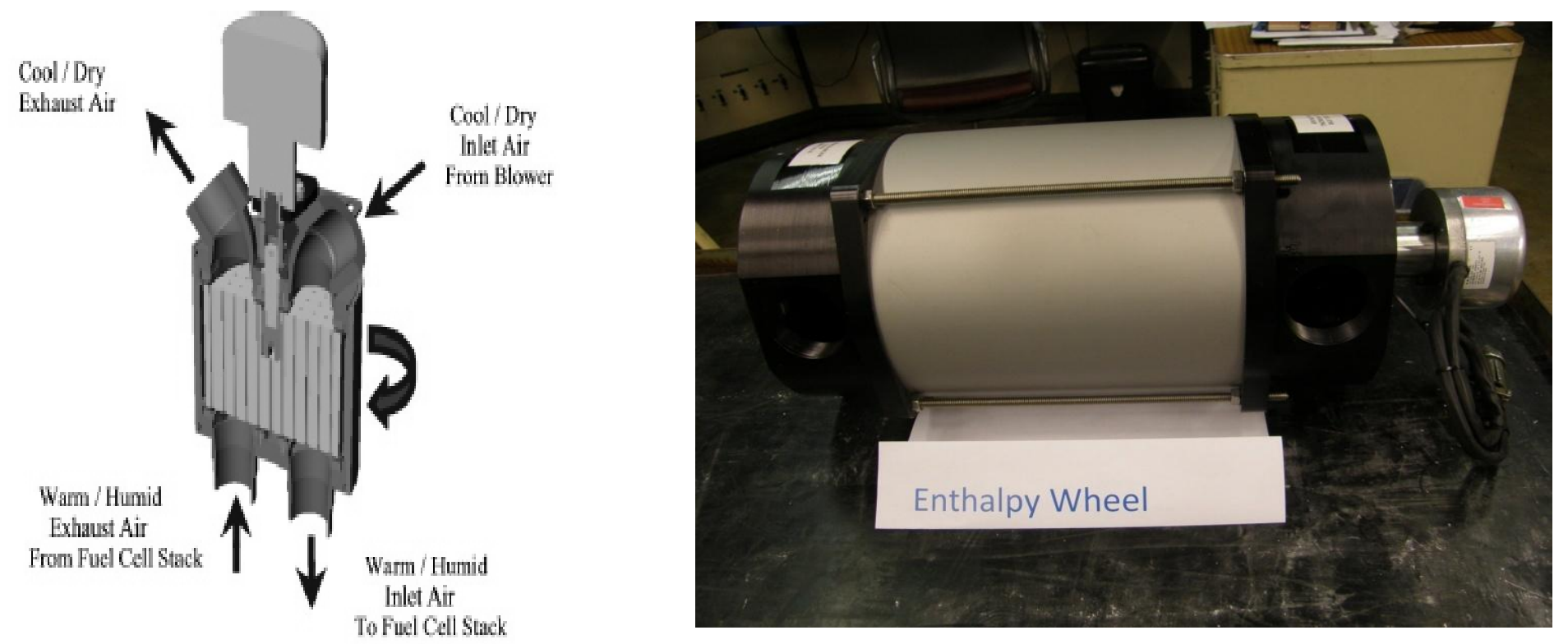


\section{Membrane Module}

- Supplied by Perma Pure, Cincinnati, OH

- Membrane selectively allows water to pass through

- Performance sensitive to temperature

- Volume 6" Dia, 10" length cartridge

- 7,000 fibers, 0.045" OD and 11 in in ${ }^{2}$ Nafion

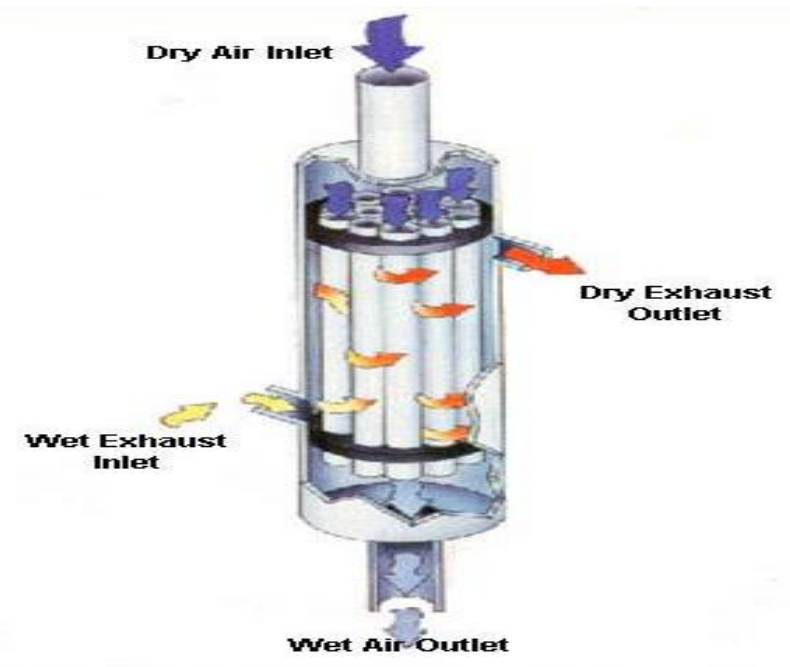

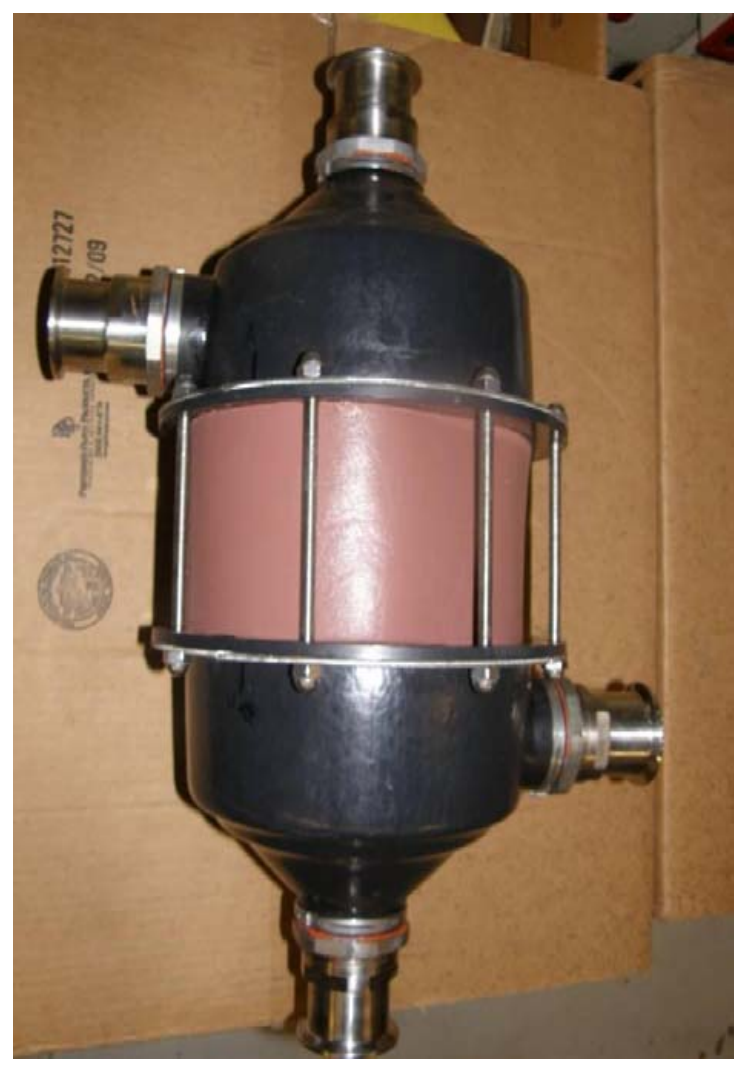

Full-scale 


\section{Planer Membrane Humidifier}

- Planer humidifier has advantage in manufacturing cost and installation

- Max operating temp. $176^{\circ} \mathrm{F}\left(80^{\circ} \mathrm{C}\right)$, pressure of 35 psi \& flow $12 / \mathrm{min}$

- Supplier: dpoint Technologies Inc., Vancouver

- Size 11.5" length, 9.3" width, and 5.4" height

- Model Px4-268 mm pleated humidifier

- Max. air flow rate of $12 \mathrm{lb} / \mathrm{min}$

- Membrane by Gore

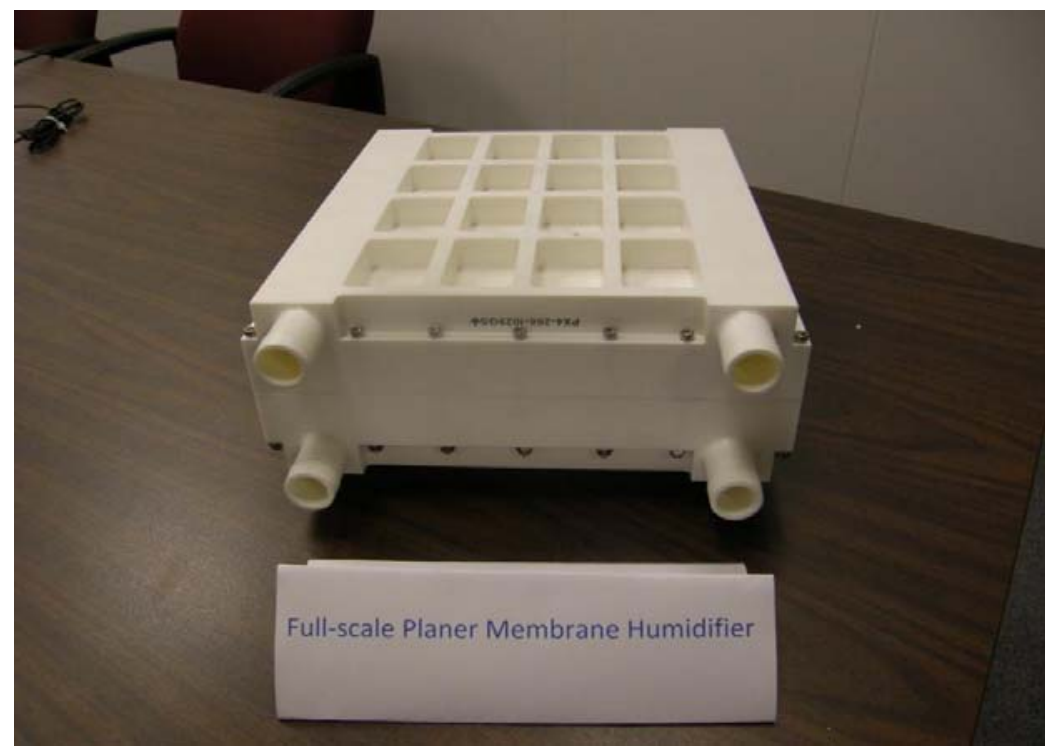




\section{Humidification Test Stand Improvements}

- Test stand was modified to measure the water injection rate by weight

- Water was condensing inside the test article, instead of being transferred

- Improve steam line insulation

- Add heater tape and improved insulation to ducting to ensure duct wall temps stay above dew point temperature

- Additional humidity sensors were added in addition to dry-wet bulb devices

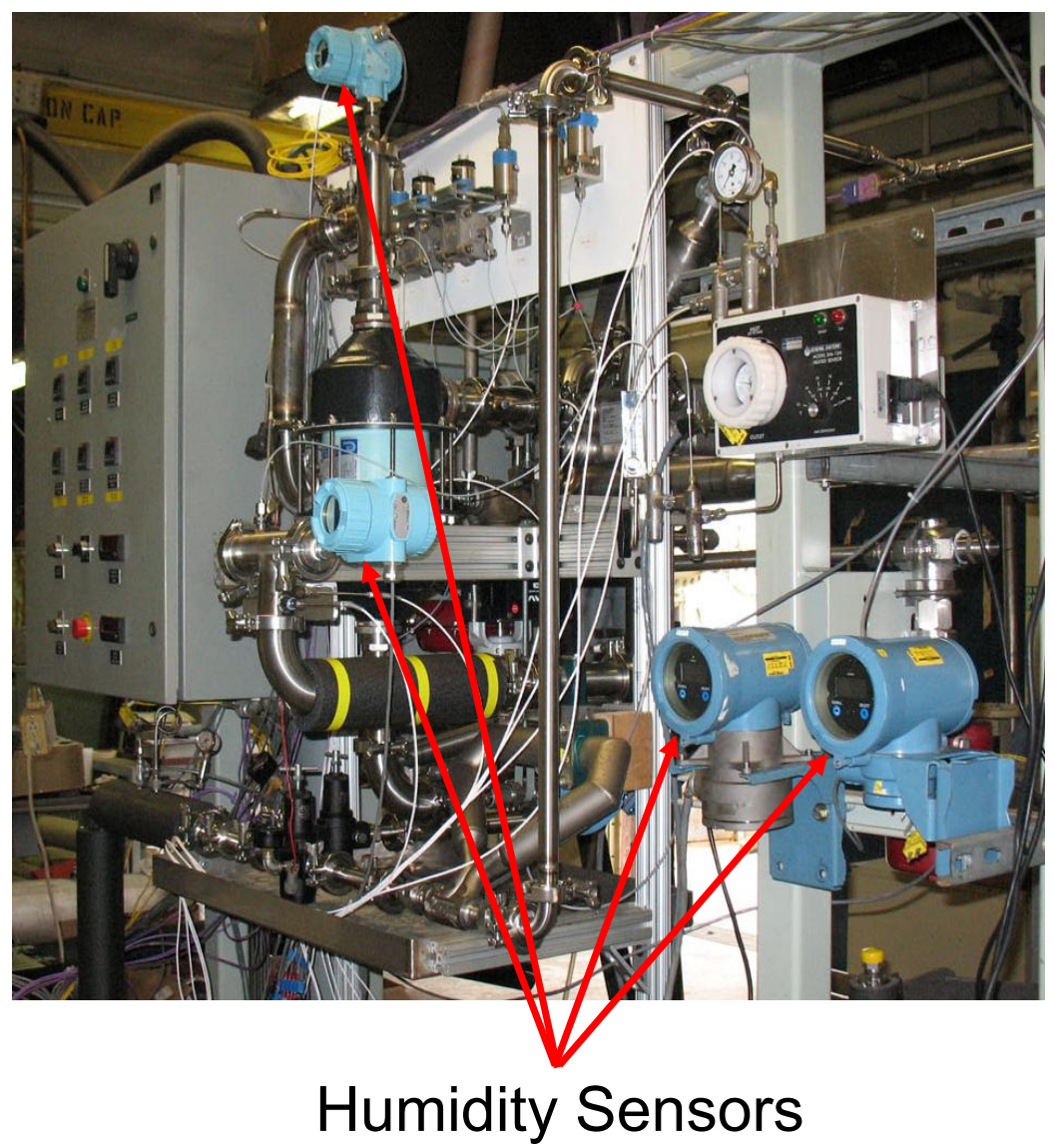




\section{Honeywell}

\section{Humidification Test Stand (Contd.)}

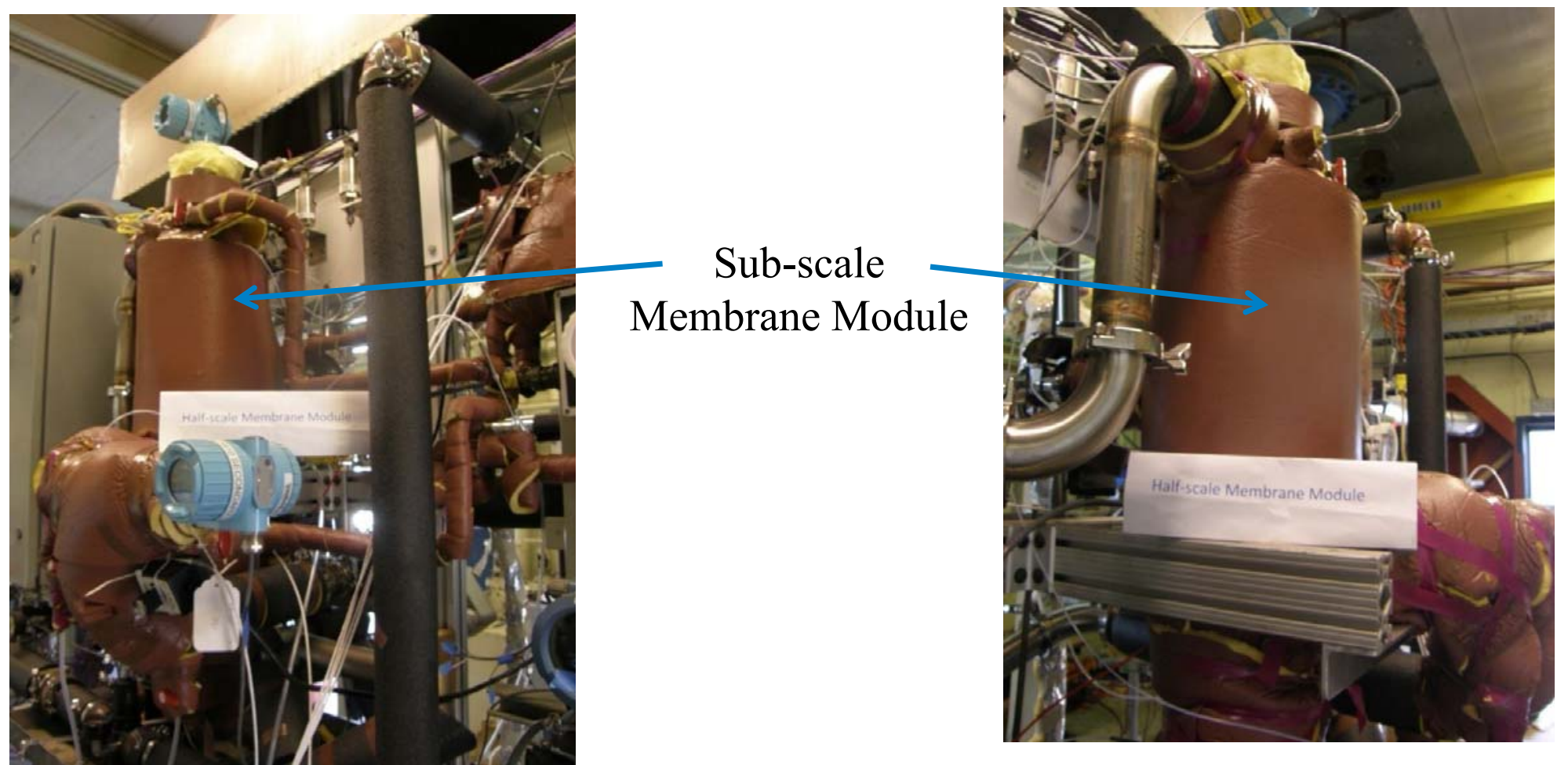

Sub-scale Membrane Module under test 


\section{Honeywell}

\section{Humidifier Test Result Summary}

\begin{tabular}{|l|c|c|}
\hline \multicolumn{1}{|c|}{ Humidifier } & $\begin{array}{c}\text { Water Balance } \\
\text { (Ave. in \%) }\end{array}$ & $\begin{array}{c}\text { Water Transfer Ratio } \\
\text { (Ave in \%) }\end{array}$ \\
\hline Full Scale Membrane Module & $10-20$ & $20-35$ \\
\hline Sub-scale Membrane Module & $10-15$ & $20-35$ \\
\hline Planer Membrane Module & $10-20$ & $20-35$ \\
\hline Enthalpy Wheel & $5-15$ & $40-75$ \\
\hline
\end{tabular}

Current fuel cell inlet air humidification requirements $>60 \%$

This document is the property of Honeywell International Inc. It is furnished for evaluation purposes and may not be duplicated, used, or disclosed in whole or in part for any other purpose without the prior written permission of Honeywell International Inc. 


\section{Honeywell}

\section{Go-forward Plan Options}

1. Test reliability of the select humidification devices by cycling the humidity in air stream

2. Acquire a more accurate humidity sensing device and retest all four systems. [VIASENSOR HS-1000 Humidity Sensor by Landtec, claims accuracy of $+/-2 \%]$

\section{Honeywell recommend Option 1 concurred by ANL}




\section{Honeywell}

\section{Schedule}

\begin{tabular}{|c|c|c|c|c|c|c|c|c|c|c|c|c|}
\hline ID & ( & Task Name & \begin{tabular}{|l} 
th Quarter \\
Oct Nov
\end{tabular} & \begin{tabular}{|l|l|l} 
& $1 s t$ \\
Dec & Jan
\end{tabular} & $\begin{array}{l}\text { Quarter } \\
\text { [Feb } / \text { Mar }\end{array}$ & & & & & $\begin{array}{l}\text { Uatter } \\
\text { Aug : }\end{array}$ & & $\frac{4 \text { th } Q}{0 \text { oct }}$ \\
\hline 1 & 国 & Start Go-forward plan & & 1219 & & & & & & & & \\
\hline 2 & & Finalize Test Plan & & 7 & & & & & & & & \\
\hline 3 & 国 & Modify Test Stand & & & & & & & & & & \\
\hline 4 & 国 & Testing of Hum idifier 1 & & & & ] & & & & & & \\
\hline 5 & 四 & Data Analysis & & & & B & & & & & & \\
\hline 6 & 国 & Modify Test Stand & & & & 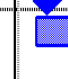 & & & & & & \\
\hline 7 & 国 & Testing of Hum difier 1 & & & & & & & & & & \\
\hline 8 & 国 & Data Analysis & & & & & & & ] & & & \\
\hline 9 & 䁅 & Program Final Report Draft & & & & & & & & & & \\
\hline 10 & 国 & Incorporate DOE comments & & & & & & & - & & & \\
\hline 11 & 国 & Final Report submittal & & & & & & & & & $315^{-1}$ & \\
\hline 12 & & & & & & & & & & & & \\
\hline 13 & & & & & & & & & & & & \\
\hline 14 & 四 & & & & & & & & & & & \\
\hline
\end{tabular}

